\title{
DIREITO AMBIENTAL E RESÍDUOS SÓHIDOS: PERSPECTIVA (INTER)NACIONAL TRANSDISCIPLINAR DOS 17 ODS DA ONU
}

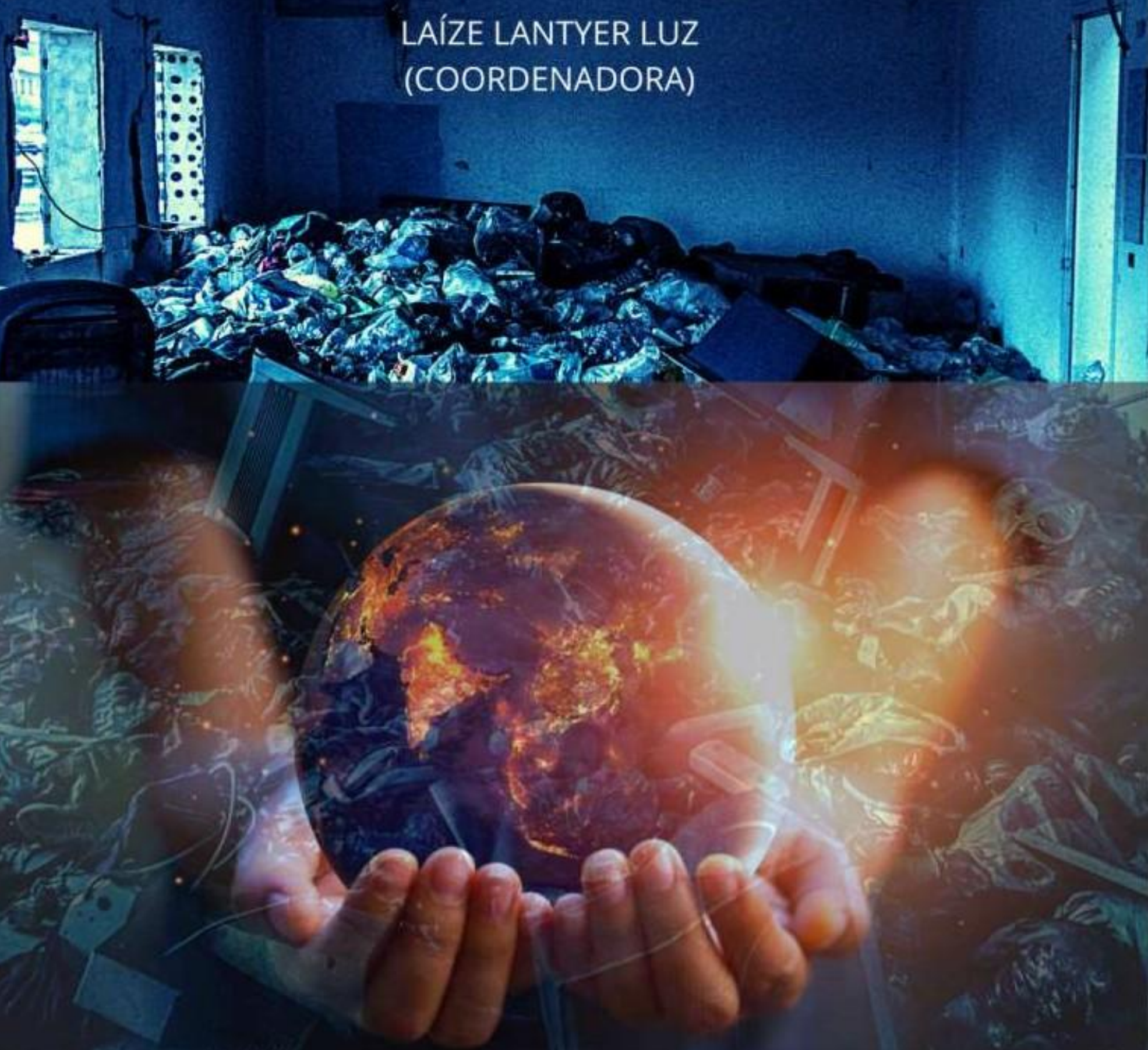




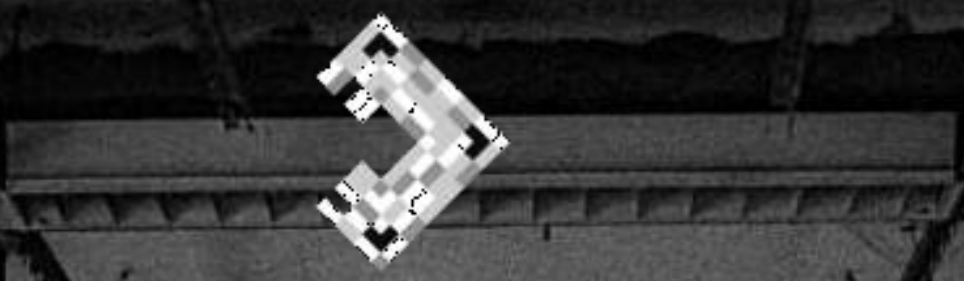

\section{DIREITO AMBIENTAL E RESÍDUOS SÓLIDOS: PERSPECTIVA (INTER)NACIONAL TRANSDISCIPLINAR DOS 17 ODS DA ONU}

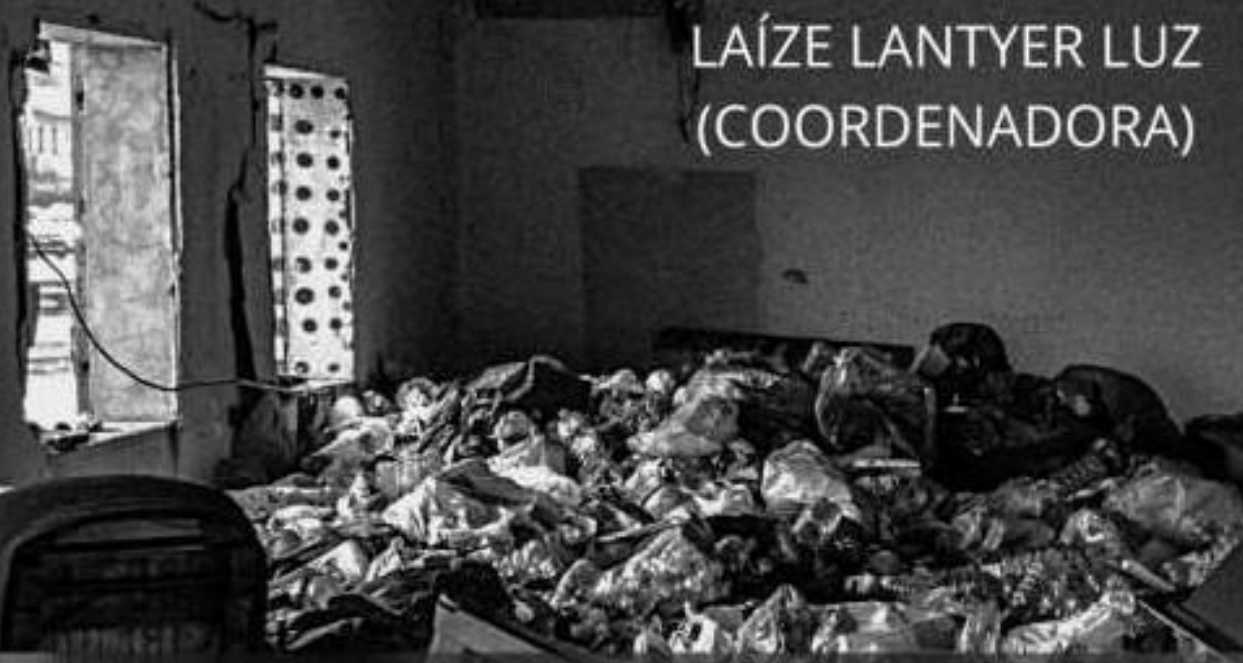

LAIZE LANTYER LUZ

(COORDENADORA) 


\section{CONSELHO EDITORIAL}

Doutores:

Profa. Aída Cristina do Nascimento Silva

Prof. André Alves Portella Profa. Andréa Cardoso Ventura

Profa. Isabel Colucci Coelho
Profa. Silvana Sá de Carvalho Prof. Urbano Félix Pugliese do Bomfim

\section{Mestres:}

Profa. Ana Paula Mendes Geitenes Prof. Diogo Assis Cardoso Guanabara Profa. Sara Meireles

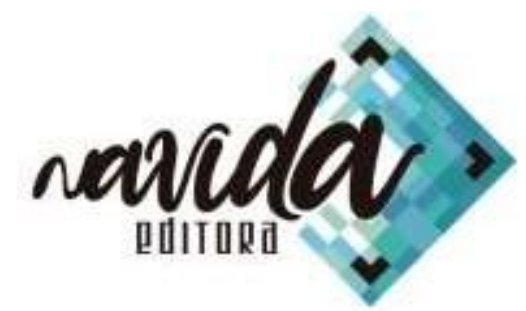

www.navidaeditora.com

contato@navidaeditora.com

https://doi.org/10.51968/NAVIDA.DIREITOAMBIENTALERESIDUOS

Dados Internacionais de Catalogação na Publicaçăo (CIP)

(Câmara Brasileira do Livro, SP, Brasil)

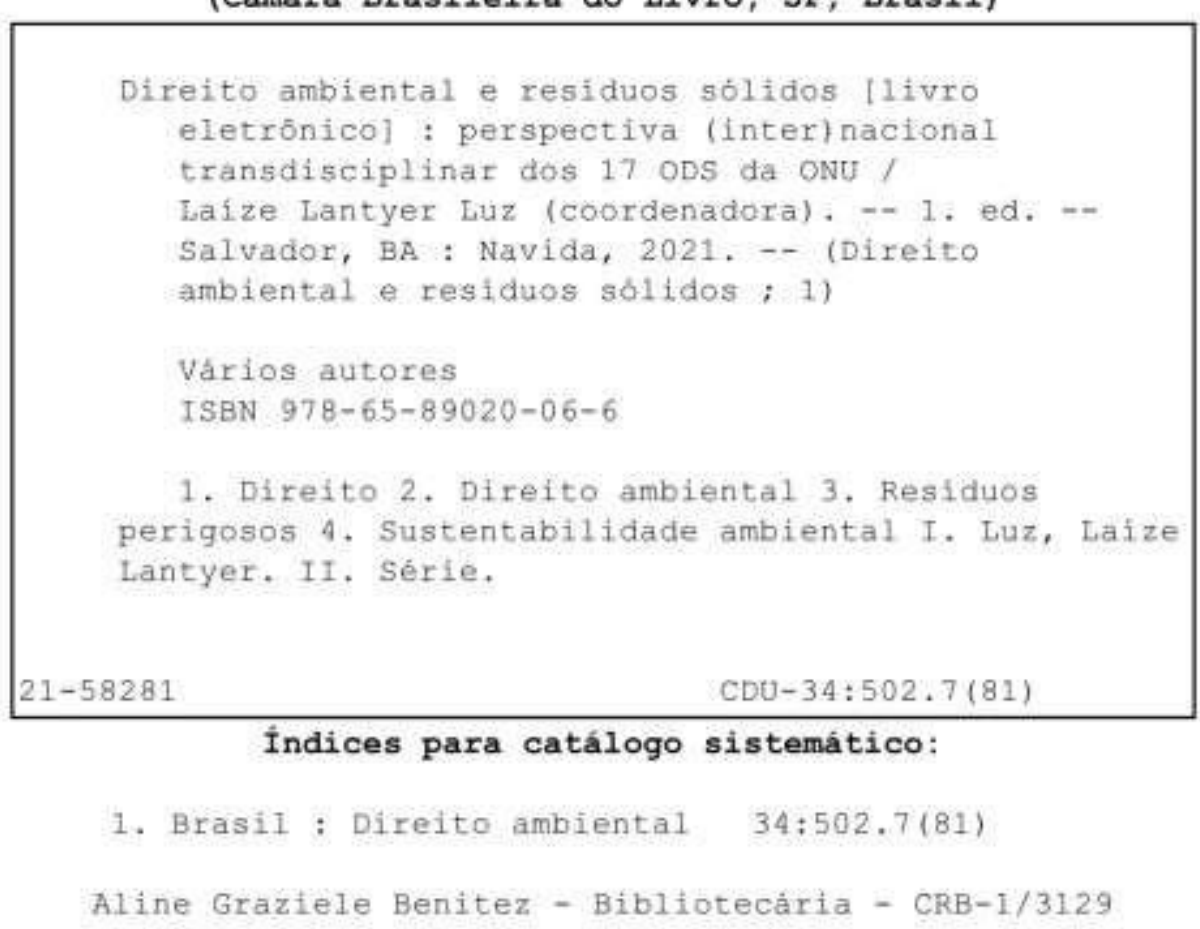




\section{SUMÁRIO}

PREFÁCIO

I...

A INCLUSÃO LABORAL DOS CATADORES DE MATERIAIS RECICLÁVEIS E REUTILIZÁVEIS

II 20

O DESCARTE INCORRETO DE RESÍDUOS SÓLIDOS E SUA INFLUÊNCIA NA SAÚDE PÚBLICA

III 29

O CONSUMO E A SOCIEDADE CONTEMPORÂNEA:

DESAFIOS DA ADMINISTRAÇÃO PÚBLICA NA GESTÃO DO CONSUMO CONSCIENTE...29

IV 40

RESÍDUOS SÓLIDOS EM UMA SOCIEDADE DE CONSUMO .. .40

$\mathrm{V}$

PEGADA ECOLÓGICA, ODS 12 E GESTÃo DE RESÍDUOS

VI53

O PRINCÍPIO DA EQUIDADE INTERGERACIONAL NA LOGÍSTICA REVERSA DOS RESÍDUOS SÓLIDOS

VII 65

RESÍDUOS SÓLIDOS E MUDANÇAS CLIMÁTICAS SOB A PERSPECTIVA DOS OBJETIVOS DE DESENVOLVIMENTO SUSTENTÁVEL

VIII 77

A FANTÁSTICA FÁBRICA DE BRINQUEDOS:

O (DES)CUMPRIMENTO DAS METAS PARA O DESENVOLVIMENTO SUSTENTÁVEL DA

AGENDA 2030.

IX92

A EDUCAÇÃo AMBIENTAL E GESTÃo EFICIENTE DAS POLÍTICAS PÚBLICAS DE RESÍDUOS MUNICIPAIS: OS EXEMPLOS DE SALVADOR E FLORIANÓPOLIS......................92

$\mathbf{X}$

O IPTU VERDE DE SALVADOR NA GESTÃo DE RESÍDUOS SÓLIDOS.. .105

XI 105

DIREITO À CIDADE SUSTENTÁVEL EM UMA SOCIEDADE LIXO ZERO

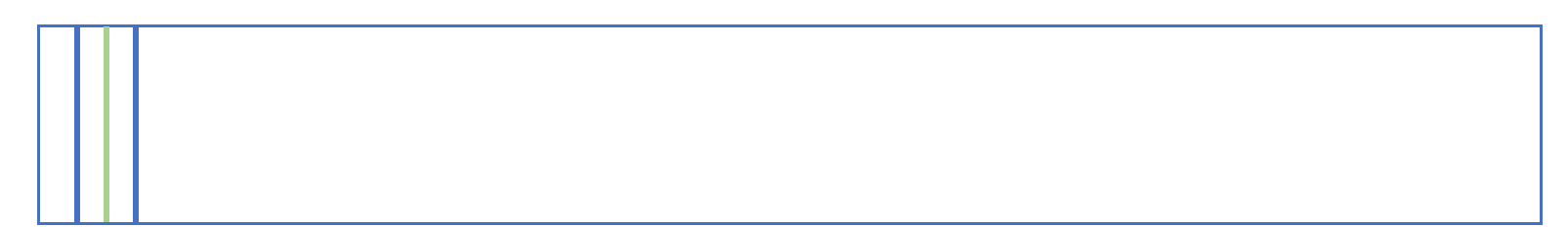




\section{PREFÁCIO}

Temos presenciado sujeitos sociais enclausurados, diariamente, e por muito tempo, o vírus da cegueira coletiva. As vivências com as múltiplas degradações e a lavagem de mãos contra o meio ambiente. O resíduo, ou popular lixo, é uma produção humana. Quer individualmente, quer por meio de coletivos de empresas públicas e/ou privadas nacionais ou transnacionais, todo o ser humano deixa um rastro de resíduo do berço ao túmulo.

Em desprezo a todos os alertas aparentemente (in)visíveis nos lixões ainda presentes em todo o mundo, relatórios científicos, recomendações, tratados, decretos, portarias e leis atualizadas como a Política Nacional de Resíduos Sólidos (PNRS), têm esvaído no ar como fumaça gasosa. O Brasil é a ponta do iceberg de uma montanha de lixo oriunda do consumo de analfabetos ambientais, e conectados ao wifi, são tão desligados da ancestralidade do Ser e da natureza, que nos cerca e nutre do ar, da água e alimento, todos os dias.

Em meio a essas e outras realidades desalinhadas e legislações ineficientes, os pesquisadores aqui reunidos, neste livro, propõem-se a tratar de um tema desafiador, de interesse mundial e ainda pouco explorado. Partindo do direito ambiental, gestão e engenharia, áreas de atuação de seus autores, sob o título "Direito Ambiental e Resíduos Sólidos: perspectiva (inter)nacional transdisciplinar dos 17 objetivos do desenvolvimento sustentável (ODS)".

Direito Ambiental e Resíduos Sólidos busca contemplar uma abordagem desafiadora que exige soluções sistêmicas respaldadas nos 17 (dezessete) objetivos do desenvolvimento sustentável, a saber: a inclusão laboral dos catadores de materiais recicláveis e reutilizáveis, o descarte incorreto de resíduos e sua influência na saúde, o consumo e a sociedade contemporânea, o princípio da equidade intergeracional na logística reversa, a pegada ecológica, IPTU Verde, o direito à cidade sustentável, cidades lixo zero, o demonizado plástico, consumo infantil de brinquedos e a educação ambiental como ferramenta de gestão das políticas públicas. 
Em cada estudo apresentado nesta obra, seus autores favorecem a leitura crítica e reflexiva por parte dos leitores para a cura do vírus da ignorância, o alinhamento entre pensamentos, palavras e atos ambientalmente corretos. Tais aspectos permitirão que seja possível alcançarmos as metas estabelecidas pela ONU, em 2015, quando foi aprovada a Agenda 2030, na qual elencou os 17 Objetivos de Desenvolvimento Sustentável (ODS), a serem perseguidos por todos os cidadãos do mundo, em cooperação até o ano 2030.

Salvador, 26 de janeiro de 2021.

Laíze Lantyer Luz

Advogada. Integrante da Comissão de Meio Ambiente da OAB-BA Doutoranda e Mestra em Políticas Sociais e Cidadania (UCSAL) Especialista em Direito Ambiental e Pós-graduanda em Gestão de Resíduos Sólidos Socialmente Integrados (GERSI/UFBA).

Aída Cristina do Nascimento Silva Engenheira Sanitarista (UFBA) Especialista em Regulação/ANS/Ministério da Saúde e Professora da UFBA Doutora em Saúde Coletiva/Instituto de Saúde Coletiva/UFBA 


\title{
A INCLUSÃO LABORAL DOS CATADORES DE MATERIAIS RECICLÁVEIS E REUTILIZÁVEIS
}

\author{
Agenor Calazans da Silva Neto ${ }^{1}$
}

Nesse momento a humanidade vivencia uma das mais graves emergências de saúde pública das últimas décadas. E para o enfrentamento desta emergência decorrente da pandemia do coronavírus (COVID-19), abruptamente a sociedade teve que adotar medidas de distanciamento e isolamento social que afetaram a produção econômica, ocasionando a perda do emprego e da renda de milhares de trabalhadores e trabalhadoras.

Segundo estudo realizado pela Organização das Nações Unidas (ONU), apenas no primeiro mês da crise econômica decorrente da pandemia de COVID-19, centenas de milhões de empregos foram perdidos. O mesmo estudo aponta que, no mesmo período, houve também uma perda de $60 \%$ dos rendimentos por parte das trabalhadoras e trabalhadores informais (ONU, 2020).

Os trabalhadores que atuam na área de resíduos sólidos, mais especificamente as mulheres e homens que atuam na essencial tarefa de coleta e seleção de materiais recicláveis, enfrentam justamente esta realidade descrita. Parte dos que possuíam vínculo formal de emprego agora estão desempregados. Já os autônomos, maior parte da categoria, enfrentam a perda drástica da renda e se submetem ao risco grande de contaminação para manter a própria subsistência e da família.

Conforme informa o Movimento Nacional dos Catadores de Materiais Recicláveis (MNCMR), no Brasil existem atualmente cerca de 800 mil catadores e catadoras (MNCMR, 2020). A situação rotineira de trabalho da grande maioria destes profissionais já é deveras precária, degradante e estigmatizada, apesar do

\footnotetext{
${ }_{1}^{1}$ Advogado. Especialista em Direito Urbanístico e Ambiental pela Pontifícia Universidade Católica de Minas Gerais (PUC Minas). Bacharel em Direito pela Universidade Federal da Bahia (UFBA). Membro do grupo de pesquisa Direito Ambiental e Resíduos Sólidos em uma perspectiva local e internacional (LAEJU).
} 
reconhecimento formal nas leis e políticas ambientais da natureza fundamental da atividade que desenvolvem (PASQUALETO, 2020).

Estes profissionais convivem com o preconceito e a discriminação da sociedade, que, por um processo histórico e cultural fomentado pelo vigente modelo de produção e consumo, não reconhece no catador a imagem de um verdadeiro trabalhador, já que a visão equivocada do senso comum é de que ele vive do lixo e nada produz (LUZ, 2019).

A ONU, em 2015, aprovou a Agenda 2030 na qual elencou 17 Objetivos de Desenvolvimento Sustentável (ODS) a serem alcançados por todos os países até o ano 2030, tendo como mote a ideia de "não deixar ninguém para trás" (ONU, 2020).

Um desses objetivos (ODS 8) é "promover o crescimento econômico sustentado, inclusivo e sustentável, emprego pleno e produtivo e trabalho decente para todas e todos", fixando como metas, por exemplo, a promoção de políticas orientadas para a geração de emprego decente, proteger os direitos trabalhistas e promover ambientes de trabalho seguros e protegidos para todos os trabalhadores, e até 2030 alcançar o emprego pleno e produtivo e trabalho decente para todas as mulheres e homens (ONU, 2020).

Tendo como vetor o mencionado ODS 8 da Agenda 2030 da ONU, o presente estudo analisa quais são os direitos trabalhistas assegurados na legislação brasileira aos catadores de materiais recicláveis. Para tanto, verificará se a legislação vigente assegura a esta categoria a garantia do emprego pleno e do trabalho decente. Em seguida, analisará ainda em que medida as políticas públicas que vêm sendo adotadas pelo governo federal estão direcionadas à meta de desenvolvimento sustentável baseada na geração de emprego decente, proteção de direitos trabalhistas e promoção de ambientes de trabalho seguros e protegidos para essa categoria de trabalhadores.

O estudo foi realizado por meio de pesquisa bibliográfica e documental, primeiramente analisando o tratamento do tema nas leis e doutrinas trabalhistas nacionais. Em seguida foi feita a análise do tratamento conferido nas leis e doutrina jurídica ambiental brasileira. Foram também coletadas e analisadas informações constantes de notícias e artigos publicados em site e jornais de organizações governamentais e não governamentais dirigidos ao público em geral, bem como requisitadas informações à Secretaria de Trabalho do Ministério da Economia por meio do serviço de informação ao cidadão.

Deste modo, em um primeiro momento, o presente trabalho apresenta as principais formas de trabalho dos catadores de materiais recicláveis e suas 
características, e analisa os direitos destes profissionais na perspectiva da relação de emprego, do trabalho em cooperativas e do trabalho avulso. Em seguida, interpreta as leis e políticas públicas que vêm sendo aprovadas no Brasil, em especial a Política Nacional de Resíduos Sólidos (PNRS) e o Plano Nacional de Resíduos Sólidos (PLANARES). Por fim, identifica perspectivas futuras para o trabalho e os direitos dos catadores de materiais recicláveis, analisando a (ex)inclusão social destes profissionais à luz dos 17 ODS da ONU.

\section{A TUTELA JURÍDICA DO TRABALHO DOS CATADORES DE MATERIAIS RECICLÁVEIS: EMPREGADO(A), COOPERADO(A) E AVULSO(A)}

Na sociedade contemporânea, o trabalho é um direito humano reconhecido na Declaração Universal dos Direitos Humanos da ONU, sendo consagrado também na Constituição da República Federativa do Brasil (CRFB) como fundamento da república (art. $1^{\circ}$, IV), direito social (art. $6^{\circ}$ ) e princípio da ordem econômica (art. 170, VIII).

A concepção contemporânea do trabalho evidencia que não é qualquer atividade laboral que concretiza o direito em questão. É essencial que o trabalho dignifique aquele que o exerce, de modo que o trabalho reconhecido como direito humano e fundamental é o trabalho digno e decente. (LEITE, 2016).

Segundo estudo apresentado pelo Instituto de Pesquisa Econômica Aplicada (IPEA), é do século XIX os primeiros indícios da realização da atividade da catação de materiais recicláveis como um meio de trabalho (IPEA, 2013). Desde então, o contingente de catadores e catadoras cresceu de forma exponencial, atrelado ao processo de urbanização, e já representa uma categoria com cerca de 800 mil profissionais conforme a estimativa do MNCMR. (MNCMR, 2020).

A Lei 12.305, de 2 de agosto de 2010, que instituiu a PNRS, no art. $6^{\circ}$, VIII, reconhece o resíduo sólido reutilizável e reciclável como um bem econômico e de valor social, gerador de trabalho e renda e promotor de cidadania, sendo esse reconhecimento um princípio da própria política estabelecida.

Antes da referida lei, a atividade profissional dos catadores e separadores de materiais reutilizáveis e recicláveis foi reconhecida formalmente pelo Ministério do Trabalho e Emprego em 2002, estando previsto na Classificação Brasileira de Ocupações (CBO). Conforme descrição na $\mathrm{CBO}$, a atividade: 
indústrias recicladoras para reinserção dos resíduos em suas ou em outras cadeias produtivas, em substituição ao uso de matérias-primas virgem (MMA, 2020).

Atualmente, identificam-se catadores trabalhando de três principais formas: empregado, prestando serviço subordinado a um empregador e regido pela CLT, ou autônomo, prestando serviço por conta e risco próprio, este podendo se dar coletivamente, por meio de cooperativas, ou individualmente, sendo neste último caso conhecido como catador avulso.

Dados fornecidos pela Secretaria de Trabalho do Ministério da Economia informam que em junho de 2020 havia apenas 11.468 vínculos de empregos formais ativos relativos às ocupações de catação e separação de materiais reutilizáveis e recicláveis no Brasil (CBO 5192-05 e 5192-10), o que revela que pouco mais de 1\% (um por cento) do total de catadores e separadores possuem emprego protegido pela Consolidação das Leis do Trabalho (CLT).

$\mathrm{O}$ art. $3^{\circ}$ da CLT dispõe que "considera-se empregado toda pessoa física que prestar serviços de natureza não eventual a empregador, sob a dependência deste e mediante salário". Diante do conceito legal, Carlos Henrique Bezerra Leite apresenta um conceito doutrinário compreendendo ser o empregado:

espécie de trabalhador subordinado que, com tal ânimo, de forma não eventual e mediante remuneração, coloca pessoalmente a sua força de trabalho à disposição de uma outra pessoa física ou jurídica, em decorrência de um contrato de trabalho (LEITE, 2016, p. 164).

Conforme já dito, a existência de uma relação de emprego confere ao empregado a proteção da CLT, assegurando direitos trabalhistas mínimos. Nesse contexto, o(a) catador(a) empregado(a) goza de uma situação muito mais segura do que o(a) catador(a) autônomo(a).

$\mathrm{O}$ (A) catador(a) empregado(a) possui, dentre outros direitos, a garantia do salário mínimo (art. $7^{\circ}, \mathrm{IV}$, da CRFB e art. 76 da CLT); a limitação da jornada a 8 horas diárias e 44 horas semanais (art. $7^{\circ}$, XIII, da CRFB e art. 58 da CLT); intervalo intrajornada mínimo de 15 minutos para jornadas superiores a 4 horas e mínimo de 1 hora para jornadas superiores a 6 horas; intervalo interjornadas mínimo de 11 horas (art. $7^{\circ}$, XIII, da CRFB e art. 58 da CLT); repouso semanal remunerado e feriados (art. $7^{\circ}$, XV e XXXIV, da CRFB e Lei no 605/49), além de férias (art. 129 da CLT) e fundo de garantia por tempo de serviço (art. $7^{\circ}$, III, da CRFB e Lei n ${ }^{\circ} 8.036 / 90$ ) 
Além de todo esse rol de direitos, os catadores empregados gozam ainda de tutela em relação à segurança e medicina do trabalho, contando com direitos específicos voltados à proteção do meio ambiente do trabalho (art. 225 da CRFB), a redução dos riscos inerentes do trabalho (art. $7^{\circ}$ da CRFB) e a proteção de sua saúde, sendo estes os mais graves problemas relacionados à atividade dos catadores de materiais recicláveis e reutilizáveis.

Nesse contexto, o empregador deve assegurar ao catador(a) empregado(a), por exemplo, equipamentos de proteção individual (luva, máscara, bota etc.), locais adequados para refeição e utilização de banheiros, além de pagar adicional de insalubridade e/ou periculosidade (art. 192 e 193 da CLT). É importante pontuar que a Norma Regulamentadora $\mathrm{n}^{\mathrm{o}} 15$, do antes denominado Ministério do Trabalho e Emprego (MTE), considera como insalubre em grau máximo a atividade em contato permanente com lixo urbano.

Esses são apenas alguns dos direitos básicos que catadores com vínculo formal de emprego possuem e que conferem um patamar mínimo e essencial de dignidade ao trabalhador(a). Além desses, poderiam ser citados ainda com grande relevância normas de proteção laboral à gestante, à maternidade/paternidade, à infância e ainda reflexos em direito previdenciários que garantem proteção contra riscos sociais (doença, invalidez etc.) e aposentadoria.

Noutro giro, o(a) catador(a) autônomo(a) não possui relação de emprego, não estando sob a tutela do direito do trabalho, não sendo, portanto, destinatário(a) das normas da CLT. Vólia Bomfim Cassar ensina que autônomo é "o trabalhador que explora seu ofício ou profissão com habitualidade, por conta e risco próprio" (CASSAR, 2017, p. 282). Leite, ademais, acrescenta que “o autônomo não transfere para terceiro o poder de organização de sua atividade, pois desenvolve com discricionariedade, iniciativa e organização próprias, escolhendo o lugar, o modo, o tempo e a forma de execução dos serviços" (LEITE, 2016, p. 165).

Conforme mencionado, grande parte dos catadores no Brasil atuam coletivamente através de cooperativas de trabalho. A Lei 12.605/2012 ("Lei das Cooperativas") estabelece normas de organização e o funcionamento das Cooperativas de Trabalho, constando no seu art. $2^{\circ}$ o seu conceito legal como sendo: condições gerais de trabalho. (BRASIL, 2012) 
Não existe relação de emprego entre a cooperativa e os seus cooperados. A organização em cooperativa pressupõe a adesão voluntária e livre, gestão democrática, além de autonomia e independência de seus membros (art. $3^{\circ}$, I, II, IV, da Lei 12.605/2012). A ausência desses requisitos evidencia não tratar-se de verdadeira cooperativa, mas de mera fraude, na tentativa de ocultar verdadeira relação de emprego e sonegar ao trabalhador a proteção prevista na CLT.

As verdadeiras cooperativas, então, possuem escopo de prestar serviços e auxiliar os seus cooperados em suas atividades. Nesse sentido, a organização em cooperativa de trabalho oferece (ou deveria oferecer) ao catador(a) autônomo(a), por exemplo, maior poder de negociação dos materiais catados, maior poder de negociação de demandas juntos ao Poder Público, suporte no desenvolvimento das atividades, com disponibilização de galpão, banheiro, refeitório e equipamentos de proteção individual (luva, máscara, bota etc.) etc.

As cooperativas, conforme o art. $8^{\circ}$ da Lei $n^{\circ} 12.690 / 2012$, possuem o dever de “observar as normas de saúde e segurança do trabalho previstas na legislação em vigor e em atos normativos expedidos pelas autoridades competentes". (BRASIL, 2012).

A atuação através de cooperativa de trabalho confere ao catador ainda uma proteção um pouco melhor de direitos previdenciários, já que, para fins de contribuição previdenciária, a Lei 8.212/91 equipara as obrigações das cooperativas àquelas previstas para as empresas.

Apesar do papel relevante que as cooperativas apresentam, sua efetividade se revela mais destacada quanto ao desenvolvimento da solidariedade e ajuda mútua entre os associados. No viés da proteção efetiva de direitos trabalhistas, a vulnerabilidade apresentada por catadores cooperados é ainda muito grande.

$\mathrm{O}$ ingresso em cooperativas de trabalho é medida paliativa que possibilita ao catador o acesso a um patamar mínimo de direitos, mas não assegura o desejado emprego decente, com proteção de direitos trabalhistas e ambientes de trabalho seguros. Conforme elucida Laíze Luz, a inclusão do catador em uma cooperativa serve mais à finalidade de incluir o catador de rua e em situação de rua no radar do mercado consumidor do que propriamente para a proteção de seus direitos (LUZ, 2020).

O avulso, por sua vez, também não goza de proteção da CLT e tampouco das normas que regulamentam cooperativas de trabalho, enfrentando os desafios da profissão inteiramente à sua própria sorte. Assim, o catador(a) avulso(a), muitos(as) em 
situação de rua, em regra, não têm acesso a equipamentos de proteção individual adequados, ficando expostos(as) aos riscos constante de cortes e quedas, contaminação por materiais químicos e biológicos descartados inadequadamente, contato direto com animais, como ratos e moscas, além do mau cheiro e da inalação de gases decorrente da decomposição do lixo.

$\mathrm{O}(\mathrm{A})$ avulso(a) não goza, assim como o(a) cooperado(a), de garantia de renda básica mínima e costumam atuar em jornadas extensas, sem descansos. Além disso, apesar da lei previdenciária permitir o recolhimento de contribuição direta pelo trabalhador(a), diante da necessária escolha entre ter o que comer ou contribuir para a previdência, os(as) trabalhadores(as) avulsos(as) em geral não gozam de proteção da Previdência Social ${ }^{2}$, ficando sem proteção trabalhista ou previdenciária em caso de doença ou acidente, bem ainda sem gozar de aposentadoria quando idosos.

O trabalho do(a) catador(a) avulso(a) fica, portanto, à margem da tutela jurídica estatal efetiva, sendo praticamente inexistentes medidas legais de proteção ao trabalho desses profissionais.

\section{A INCLUSÃO DO CATADOR NAS LEIS E POLÍTICAS PÚBLICAS}

Conforme referido anteriormente, as leis e políticas ambientais nacionais reconhecem a natureza fundamental da atividade que desenvolvem os catadores de materiais recicláveis. Nesse sentido, a Lei 12.305/2010 estabelece como um dos objetivos da PNRS a integração dos catadores de materiais reutilizáveis e recicláveis nas ações que envolvam a responsabilidade compartilhada pelo ciclo de vida dos produtos.

A mesma lei, já no inciso IV do art. $8^{\circ}$, fixa como instrumento da PNRS o incentivo à criação e ao desenvolvimento de cooperativas ou de outras formas de associação de catadores de materiais reutilizáveis e recicláveis.

Diversas outras passagens na Lei 12.305/2010 fazem referência a essa necessidade de inclusão de cooperativas e associação de catadores nas questões relacionadas ao tratamento dos resíduos sólidos, inclusive atribuindo preferência no

\footnotetext{
${ }^{2}$ Tramita no Congresso Nacional, desde 2013, a proposta de emenda à constituição (PEC) no 309, que pretende incluir o(a) catador(a) de material reciclável no rol de segurado especial da Previdência Social, bem como assegurar o benefício de aposentadoria especial para esta categoria com tempo de contribuição reduzido.
} 
repasse de verbas da União aos municípios que implantarem a coleta seletiva com a participação destas organizações (art. 18, §2, II).

A Lei 12.305/2010, nos art. $8^{\circ}$, I e art. 14, fixou como outro instrumento da PNRS a criação de Planos de Resíduos Sólidos em âmbito municipal, intermunicipal, microrregional, estadual e nacional. Nessa linha, o Governo Federal recentemente divulgou e submeteu à consulta pública o PLANARES (MMA, 2020).

O PLANARES proposto apresenta entre as diretrizes para a gestão dos resíduos sólidos urbanos a promoção da inclusão social, emancipação econômica e geração de renda, elencando estratégias voltadas a qualificar, fortalecer e formalizar a prestação de serviços por associações e cooperativas de catadores e aumentar a participação de cooperativas e associações de catadores no manejo de resíduos sólidos urbanos (MMA, 2020).

Como se vê, as leis e políticas públicas nacionais tratam a inclusão do catador na única perspectiva do trabalho cooperado ou em outras formas de associação, não havendo indicação de estratégias de incentivo ao aumento de vagas de emprego formal no setor.

O que se constata, portanto, é a priorização de um modelo de trabalho que, como visto, não confere plena proteção trabalhista e se afasta do objetivo sustentável (ODS 8) de geração de emprego decente, proteção de direitos trabalhistas e promoção de ambientes de trabalho seguros e protegidos.

$\mathrm{Na}$ realidade, a priorização e incentivo a que os catadores se organizem para trabalhar prioritariamente no modelo de cooperativas e associações é sustentado no sedutor discurso do empreendedorismo (LUZ, 2020), mas efetivamente acarreta a precarização do trabalho, notadamente diante do desabrigo de direitos trabalhistas e previdenciários.

Os argumentos de independência e autogestão que tentam justificar a priorização da inclusão do trabalho dos catadores por meio de cooperativas e associações se revelam como uma mera ilusão, na medida em que esses trabalhadores permanecem completamente dependentes das imposições feitas pela indústria da reciclagem, além de exercerem atividades que integram a cadeia produtiva das empresas, representando uma mão de obra barata e sem vínculos (LUZ, 2019).

Essa relação desequilibrada é brilhantemente descrita por Laíze Luz:

O capital extrai do meio ambiente sua matéria prima sem nenhum retorno benéfico, pois o seu principal foco é a produção de mais dinheiro. Desta 
forma, a reciclagem surge para o capital com a nítida finalidade de lucro: a mercadoria que é consumida e descartada é reutilizada ao retonar à industria como matéria-prima reciclável que será transformada em nova mercadoria em um ciclo extremamente lucrativo. Neste ciclo, o uso da força de trabalho do catador matem ganhos ao sistema capitalista e o legitima (LUZ, 2019, p. 107-108).

. Essa situação é denominada por Birbeck de "self-employed proletarians", expressão que em português corresponderia a "empregado autônomo" (BIRBECK apud MEDEIROS; MACÊDO, 2006). O trabalho do(a) catador(a) nesse modelo proporciona muito mais vantagens para as empresas do que a(o) próprio(a) trabalhador(a), já que apesar de subordinado(a), exercendo o trabalho pelo modo, no tempo e na forma estabelecida pelo tomador, fica ao desabrigo da legislação trabalhista, por conta e risco próprio, com jornadas extensas, sem remuneração fixa e justa, sem garantias de condições de trabalho dignas.

A inclusão social prevista pelas leis e políticas públicas retira dos catadores, portanto, a perspectiva do emprego formal como prioridade, o que permite realizar questionamentos acerca da qualidade e da própria veracidade da inclusão pretendida.

Luiza Medeiros e Kátia Macedo, de forma precisa, fazem a seguinte reflexão:

Mas qual a qualidade dessa inclusão? Seria o fato de estar trabalhando, não importa em quê e como, garantia de inclusão social? O fato de conseguirem garantir meios para a sua sobrevivência e a de seus familiares seria sinônimo de inclusão? Seria de fato uma inclusão ou mais uma forma de exclusão transmutada em inclusão? (MEDEIROS; MACÊDO, 2006).

É curioso que a própria Lei 12.305/2010, trouxe instrumentos, como a coleta seletiva e o sistema de logística reversa que tornaram jurídica a obrigação das empresas de procederem a destinação final ambientalmente adequada aos resíduos gerados por sua atividade, o que representaria a oportunidade de abertura de vagas de emprego justamente para catadores e selecionadores de materiais recicláveis.

Nessa perspectiva, o catador que recebe, separa e destina adequadamente resíduos produzidos por empresas, shoppings e demais geradores de resíduos ou que coleta e devolve os resíduos no sistema de logística reversa está, na verdade, exercendo uma tarefa inerente ao ciclo de produção destas atividades, cumprindo uma obrigação imposta por lei ao empreendimento, ficando clara a subordinação estrutural ${ }^{3}$ existente.

\footnotetext{
${ }^{3}$ Carlos Henrique Bezerra Leite explica que subordinação estrutural ou integrativa é a que se verifica quando o trabalhador está inserido na dinâmica e organização da atividade econômica do tomador de seus serviços. A atividade realizada pelo trabalhador integra-se aos objetivos essenciais do empreendimento. (LEITE, p. 159, 2016).
} 
Percebe-se, portanto, que os principais instrumentos da PNRS revelam oportunidades para a geração de empregos plenos aos catadores de materiais recicláveis, com proteção dos direitos trabalhistas e ambientes de trabalho seguros, mas, de forma contraditória, as políticas públicas nacionais priorizam a inclusão destes trabalhadores por meio do trabalho autônomo em cooperativas e associações.

Não se está negando a importância do cooperativismo e associativismo para o desenvolvimento das condições de trabalho dos catadores de materiais recicláveis. No entanto, diante do objetivo de promover "o crescimento econômico sustentado, inclusivo e sustentável, emprego pleno e produtivo e trabalho decente para todas e todos" (ODS 8), as políticas deveriam ser orientadas prioritariamente para a geração de emprego decente para a categoria, verdadeira condição de dignidade do trabalhador.

\section{PERSPECTIVAS FUTURAS PARA O TRABALHO E OS DIREITOS DOS CATADORES DE MATERIAIS RECICLÁVEIS}

Os catadores ingressaram na atividade em um momento que a catação e separação de materiais recicláveis destacavam-se essencialmente na perspectiva ambiental, porém, na medida em que a atividade se revelou economicamente lucrativa, os catadores foram sendo excluídos e substituídos por grandes empresas de gestão de resíduos, que muitas vezes preferem que não haja coleta e separação adequadas por ganharem pela quantidade bruta recebida e manejada (MIURA, 2004).

Além da crescente e desleal concorrência com grandes empresas de gestão de resíduos, a lucratividade colocou ainda intermediários no caminho dos catadores, que compram do(a) catador(a) o material coletado e separado a um preço irrisório e vendem a preços maiores para a indústria, retirando o lucro que deveria ser do catador (LUZ, 2020).

Nesse sentido, Luiza Medeiros e Kátia Macedo alertam que é cada vez maior a quantidade de pessoas que não retiram seu sustento da reciclagem, ou seja, que não são catadores, mas que passaram a realizar tal atividade em vista da lucratividade na venda dos materiais, o que reduz cada vez mais a renda dos catadores (MEDEIROS; MACÊDO, 2006).

Além da existência do intermediário, a própria facilitação do contato direto entre o consumidor e a indústria, possibilitando a recolocação do material reciclável ou 
reutilizável no ciclo de produção sem a participação dos catadores têm aumentado as dificuldades enfrentadas por essa categoria.

Um exemplo desta facilitação citada é a disponibilização de máquinas em que o consumidor pode depositar latas e garrafas recicláveis e imediatamente receber por elas um valor em dinheiro ou ainda acumular pontos que podem posteriormente ser trocados por descontos em impostos, conta de energia, de água, transporte público, supermercado etc (PEGN TV, 2016).

Além desse cenário, a cada dia mais se fala em Sociedade Lixo Zero, que no conceito apresentado pelo Instituto Lixo Zero Brasil "consiste no máximo aproveitamento e correto encaminhamento dos resíduos recicláveis e orgânicos e a redução - ou mesmo o fim - do encaminhamento destes materiais para os aterros sanitários elou para a incineração"(INSTITUTO LIXO ZERO BRASIL, 2020).

A ideia de máximo aproveitamento e correto encaminhamento dos resíduos neste conceito de sociedade normalmente é observada apenas do ponto de vista do consumidor e da indústria, ignorando a existência dos catadores.

Conforme aponta Laíze Luz, as políticas a serem adotadas na concretização das metas "lixo zero", se não considerarem a inclusão dos catadores de materiais recicláveis na gestão dos resíduos, como, aliás, vem sendo tratado pela maioria dos órgãos e institutos que tratam do tema, conduzirão ao absoluto abandono destes profissionais, caminhando para o aumento do desemprego e exclusão social, indo na contramão dos Objetivos do Desenvolvimento Sustentável da Agenda 2030 das Nações Unidas (LUZ, 2020).

Não bastasse, a Quarta Revolução Industrial trouxe uma revolução tecnológica, apresentando a robótica, a inteligência artificial e popularizando eficazes meios telemáticos de comunicação, possibilitando o estabelecimento de negócios inteiramente virtuais, digitais ou on-line. Essa realidade revela o risco cada vez mais concreto de catadores de materiais recicláveis serem substituídos por máquinas ou por sistemas online, como aplicativos ${ }^{4}$, sendo excluídos definitivamente do processo de gestão de resíduo, ocorrendo o que Laíze Luz denominou de Darwinismo Profissional 4.0 (LUZ, 2020).

\footnotetext{
${ }^{4}$ Um aplicativo que tenta incluir o catador nessa realidade tecnológica é o Cataki (https://cataki.org/pt/)
} 
Nesse ponto o Estado deve agir no sentido de concretizar o compromisso fundamental de proteção do trabalhador em face da automação, conforme estabelecido no art. $7^{\circ}$ da Constituição da República.

Todas as circunstâncias relatadas representam grandes desafios a serem enfrentados pelos catadores de materiais recicláveis e revelam riscos concretos à continuidade da atividade laboral exercida por estes profissionais.

Por outro lado, um fator novo que representa uma esperança de melhores condições para o futuro da categoria é a publicação da Lei 14.119, de 13 de janeiro de 2021, que institui a Política Nacional de Pagamento por Serviços Ambientais.

Trata-se de uma política pública voltada a reconhecer o direito ao pagamento para serviços que contribuam na conservação ambiental. Assim, são considerados serviços ambientais atividades individuais ou coletivas de manutenção, recuperação ou melhoria de ecossistemas (SENADO, 2020).

O pagamento por serviços ambientais é uma das principais reivindicações das organizações de catadores, uma vez que a coleta de material deve ser remunerada pelo trabalho em si, que representa uma efetiva atividade de manutenção, recuperação e melhoria do ambiente urbano, não sendo justo que ainda hoje o(a) catador(a) receba apenas o baixo valor decorrente da venda do material catado.

\section{CONSIDERAÇÕES FINAIS}

Como visto, o(a) catador(a) empregado(a) possui direitos que lhe confere uma patamar de dignidade e proteção muito superior ao gozado pelo(a) autônomo(a), seja ele(a) cooperativado(a), seja ele(a) avulso(a), sendo que a garantia do emprego pleno a todos(as) é o objetivo de desenvolvimento sustentável (ODS 8) a ser alcançado na diretriz da agenda 2030 da ONU.

Nesse sentido, políticas públicas que vêm sendo adotadas e debatidas no Brasil, em vez de buscar ampliar a oferta de empregos formais e decentes, aumentar a proteção de direitos trabalhistas e promover ambientes de trabalho seguros e protegidos para os catadores e catadores, institucionalizam a informalidade elegendo a criação e contratação de cooperativas como forma prioritária de atuação destes profissionais na cadeia de gerenciamento de resíduos.

Essa perspectiva caminha em direção contrária ao ideal de Desenvolvimento Sustentável pautado pela ONU por meio da Agenda 2030 e dos 17 Objetivos de 
Desenvolvimento Sustentável, especialmente quando se percebe que, em vez de "promover o crescimento econômico sustentado, inclusivo e sustentável, emprego pleno e produtivo e trabalho decente para todas e todos" (ODS 8) $)^{5}$, se normaliza e institucionaliza o trabalho precário e a exclusão dos catadores e catadoras do processo de desenvolvimento socioeconômico e ambiental.

A qualidade da inclusão social dos catadores de materiais recicláveis prevista nas leis e políticas públicas, ao deixar de priorizar o vínculo formal e seguro de emprego e estabelecer a atividade como meramente acessória a ser desempenhada de forma autônoma, deixando os trabalhadores por sua própria conta, coloca esta categoria historicamente hipossuficiente e vulnerável em risco ainda maior quando analisada as perspectivas futuras.

A verdade é que as leis e políticas públicas precisam rever a forma e a qualidade da inclusão socioeconômica e ambiental direcionada a categoria dos catadores e selecionadores de materiais recicláveis e reutilizáveis, reconhecendo na prática e de forma efetiva a essencialidade da tarefa desenvolvida, promovendo a proteção trabalhista destes trabalhadores.

Para se garantir o crescimento econômico sustentado, inclusivo e sustentável, "sem deixar ninguém para trás", é necessário priorizar a geração de empregos formais aos catadores, ampliar a proteção de direitos trabalhistas, com ambientes de trabalho seguro, assegurando a inclusão socioeconômica e ambiental verdadeira, concreta e perene, sendo necessário o ajuste de rumos nas políticas adotadas.

\footnotetext{
${ }^{5}$ https://nacoesunidas.org/pos2015/ods8/
} 


\section{REFERÊNCIAS}

CASSAR, Vólia Bomfim. Direito do Trabalho. 14. ed. São Paulo; Método, 2017.

INSTITUTO LIXO ZERO BRASIL. Conceito Lixo Zero [2020]. Disponível em: https://ilzb.org/conceito-lixo-zero. Acesso em: 08 de janeiro de 2020.

LEITE, Carlos Henrique Bezerra. Curso de direito do trabalho. 7. ed. São Paulo: Saraiva, 2016.

LUZ, Laíze Lantyer. Darwinismo profissional 4.0. 2020. Disponível em: http://www.justificando.com/2020/05/27/darwinismo-profissional-4-0/

LUZ, Laíze Lantyer. Direito à emancipação sustentável ou obsolescência humana? As catadoras de luxo em uma sociedade lixo zero. Salvador: PG Editorial, 2020.

LUZ, Laíze Lantyer. Direito à emancipação sustentável ou obsolescência humana? As catadoras de luxo em uma sociedade lixo zero. Salvador: PG Editorial, 2020.

LUZ, Laíze Lantyer. O direito à cidad(e)(ania) das catadoras de luxo: O acesso à justiça ambiental em uma sociedade lixo zero. Direito Ambiental: Velhos Problemas, Novos Desafios. VAZ JÚNIOR, Rubens Sérgio S. Vaz; FIGUEIREDO NETO, Pedro Camilo De (coords.). Salvador: Editora Mente Aberta, p. 103-114, 2019

MEDEIROS, Luiza Ferreira Rezende de; MACÊDO, Kátia Barbosa. Catador de material reciclável: uma profissão para além da sobrevivência? Psicologia \& Sociedade, v. 18, n. 2, Porto Alegre, 2006. Disponível em:

https://www.scielo.br/scielo.php?script=sci_arttext\&pid=S0102-71822006000200009. Acesso em: 30 de agosto de 2020.

MINISTÉRIO DO MEIO AMBIENTE (MMA). Catadores de Materiais Recicláveis. Brasília, DF. [2020]. Disponível em: https://www.mma.gov.br/cidadessustentaveis/residuos-solidos/catadores-de-materiais-reciclaveis. Acesso em: 30 de agosto de 2020.

MINISTÉRIO DO MEIO AMBIENTE (MMA). Plano Nacional de Resíduos Sólidos. Brasília, DF. [2020]. Disponível em: http://consultaspublicas.mma.gov.br/planares/wpcontent/uploads/2020/07/Plano-Nacional-de-Res\%C3\%ADduos-S\%C3\%B3lidosConsulta-P\%C3\%BAblica.pdf Acesso em: 08 de novembro de 2020.

MIURA, Paula Orchiucci Cerantola.Tornar-se catador: uma análise psicossocial. Dissertação apresentada a Pontifícia Universidade Católica de São Paulo no mestrado em Psicologia Social, orientadora Dra. Bader Sawaia. São Paulo, SP, 2004. Disponível em: https://tede2.pucsp.br/bitstream/handle/17373/1/Paula\%20Miura\%20completa.pdf. Acesso em: 10 de novembro de 2020

MOVIMENTO NACIONAL DOS CATADORES DE MATERIAIS RECICLÁVEIS (MNCMR). Quantos Catadores existem em atividade no Brasil? [2020]. Disponível em: http://mncr.org.br/sobre-o-mncr/duvidas-frequentes/quantos-catadores-existem-ematividade-no-brasil. Acesso em: 05 de outubro de 2020. 
ORGANIZAÇÃO DAS NAÇÕES UNIDAS (ONU). ONU: informais perderam 60\% dos rendimentos no $1^{\circ}$ mês da pandemia [2020]. Disponível em:

https://nacoesunidas.org/onu-informais-perderam-60-dos-rendimentos-no-1o-mes-dapandemia/. Acesso em: 30 de agosto de 2020.

ORGANIZAÇÃO DAS NAÇÕES UNIDAS (ONU). ONU: Não deixar ninguém para trás": como adaptar para sua realidade local? [2020]. Disponível em:

https://www.estrategiaods.org.br/nao-deixar-ninguem-para-tras-como-adaptar-para-suarealidade-local/. Acesso em: 08 de janeiro de 2021.

ORGANIZAÇÃO DAS NAÇÕES UNIDAS (ONU). ONU: Objetivo de

Desenvolvimento Sustentável 8. Trabalho decente e crescimento econômico [2020].

Disponível em: https://brasil.un.org/pt-br/sdgs/8. Acesso em: 08 de janeiro de 2021.

ORGANIZAÇÃO DAS NAÇÕES UNIDAS (ONU). Transformando Nosso Mundo: A Agenda 2030 para o Desenvolvimento Sustentável [2015]. Disponível em:

https://nacoesunidas.org/pos2015/agenda2030/. Acesso em: 30 de agosto de 2020.

PASQUALETO, Olívia de Quintana Figueiredo. O trabalho achado no lixo:

marginalidade e dignidade - reflexões sobre o trabalho dos catadores de material reciclável. Disponível em:

http://www.lex.com.br/doutrina_27690391_O_TRABALHO_ACHADO_NO_LIXO_M ARGINALIDADE_E_DIGNIDADE_REFLEXOES_SOBRE_O_TRABALHO_DOS_ CATADORES_DE_MATERIAL_RECICLAVEL.aspx. Acesso em: 30 de agosto de 2020.

PEQUENAS EMPRESAS GRANDES NEGÓCIOS TV (PEGN TV). Máquina troca embalagens vazias por créditos ou descontos ao consumidor [2016]. Disponível em: http://g1.globo.com/economia/pme/pequenas-empresas-grandesnegocios/noticia/2016/10/maquina-troca-embalagens-vazias-por-creditos-ou-descontosao-consumidor.html. Acesso em: 08 de janeiro de 2020.

SENADO FEDERAL (SENADO). Modificado no Senado, projeto sobre pagamento por serviços ambientais volta à Câmara. Brasília, DF. [2020]. Disponível em: https://www12.senado.leg.br/noticias/materias/2020/12/16/modificado-no-senadoprojeto-sobre-pagamento-por-servicos-ambientais-volta-acamara\#: :text=O\%20Plen\%C3\%A1rio\%20do\%20Senado\%20aprovou,de\%20Pagame nto $\% 20$ por $\% 20$ Servi\%C3\%A7os\%20Ambientais.\&text=A\%20mat\%C3\%A9ria\%20inst itui $\% 20$ pagamento $\% 2 \mathrm{C} \% 20$ monet $\% \mathrm{C} 3 \% \mathrm{~A} 1$ rio,a $\% 20$ conservar\%20\%C3\%A1reas $\% 20 \mathrm{~d}$ e\%20preserva\%C3\%A7\%C3\%A3o. Acesso em: 08 de janeiro de 2020. 


\title{
O DESCARTE INCORRETO DE RESÍDUOS SÓLIDOS E SUA INFLUÊNCIA NA SAÚDE PÚBLICA
}

\author{
Laila Machado Borba ${ }^{6}$ \\ Aída Cristina do Nascimento Silva ${ }^{7}$
}

A Agenda 2030, organizada pela Organização das Nações Unidas (ONU), em 2015, buscou identificar problemas e superar desafios sociais que ainda se encontram no mundo contemplados dentre os 17 (dezessete) objetivos de Desenvolvimento Sustentável e 169 metas pactuados entre os países. O terceiro objetivo visa o fornecimento de uma saúde de qualidade e uma vida sadia para todos (ONU, 2015). Ainda em 1948, a mesma organização, já preocupada com o tema, definiu a saúde como um estado de completo bem-estar físico, mental e social e não somente ausência de afecções e enfermidades (ONU, 1948), mas posteriormente, acrescentou ainda, que a saúde é uma fonte para a vida cotidiana. É um conceito embasado em questões sociais e pessoais. Trata-se de um direito fundamental que deve ser visto de forma coletiva a ser assegurado a todos, independentemente de raça, religião, condição socioeconômica e ideológica. Nessa convenção de 1986, foram estabelecidas as condições básicas e recursos para garantir a saúde: paz, abrigo, educação, alimentação, renda, ecossistema estável, recursos sustentáveis, justiça social e equidade (The 1st International Conference on Health Promotion, 1986).

A existência de um ecossistema estável e recursos sustentáveis são pré-requisitos para uma saúde digna. Porém, no Brasil, os estudos são escassos quanto aos riscos à saúde da população relacionados ao descarte de resíduos, assim não culminando em mudanças eficazes (Souza et al., 2013). Nesse sentido, é fundamental compreender e

\footnotetext{
${ }^{6}$ Graduanda em Direito (UCSal), integrante do grupo de pesquisa Direito Ambiental e Resíduos Sólidos em uma perspectiva local e internacional (LAEJU) e do grupo de pesquisa Gestão Ambiental e Desenvolvimento de Empreendimentos Sociais (GamDes/UCSAL). É pesquisadora voluntária de iniciação científica (PROVIC/UCSAL).

${ }^{7}$ Doutora em Saúde Coletiva do Instituto de Saúde Coletiva (ISC/UFBA) e Professora Convidada da Universidade Federal da Bahia. e-mail: aidanasci@ hotmail.com.
} 
analisar como esse descarte incorreto de resíduos sólidos impacta negativamente na saúde dos indivíduos, e Silva (2014) evidencia a importância da análise dos fatores de riscos à saúde e ao ambiente associados a presença de agentes patogênicos na massa de resíduos sólidos urbanos. Historicamente, o manejo de resíduos, sempre refletiu uma desigualdade, pois como é uma profissão desvalorizada, indigna e associada à formação de doenças, o seu descarte sempre foi tarefa destinada a pessoas de menor escala social. As notícias de viajantes e documentos disponíveis mostram essa realidade presente no Rio de Janeiro no século XIX:

\begin{abstract}
A repugnante tarefa de carregar lixo e os dejetos da casa para as praças e praias era geralmente destinada ao único escravo da família ou ao de menor status ou valor. Todas as noites, depois das dez horas, os escravos conhecidos popularmente como "tigres" levavam tubos ou barris de excremento e lixo sobre a cabeça pelas ruas do Rio. Os prisioneiros realizavam esse serviço para as instituições públicas. (EIGENHEER, 2009, p. 95).
\end{abstract}

Além do direito à saúde ser estabelecido nos 17 Objetivos da ONU, também é presente na Constituição Brasileira de 1988, como direito social (Art 6º , Brasil) e como garantidor da vida (Art 5\% , Brasil). A saúde é um direito de todos e deve ser garantida pelo Estado "mediante políticas sociais e econômicas que visem à redução do risco de doença e de outros agravos e ao acesso universal e igualitário às ações e serviços para sua promoção, proteção e recuperação" (Art 196, Brasil). Assim, é dever do Estado brasileiro promover as ações de serviços de saúde, cabendo ao poder público dispor, nos termos da lei, sobre sua regulamentação, fiscalização e controle, devendo sua execução ser feita diretamente ou através de terceiros e, também, por pessoa física ou jurídica de direito privado (Art 197, Brasil). A Política Nacional de Resíduos Sólidos (Brasil, 2010) após anos no Congresso Nacional, foi elaborada tendo como um dos seus princípios e objetivos uma saúde pública mais digna e universal. A temática é reiteradamente citada na Lei, conforme determina que "Cabe ao poder público atuar, subsidiariamente com vistas a minimizar ou cessar o dano, logo que tome conhecimento de evento lesivo ao meio ambiente ou à saúde pública relacionado ao gerenciamento de resíduos sólidos” (Brasil, 2010). No entanto, é importante declarar que embora existam legislações voltadas ao manejo de resíduos e a saúde no Brasil, ainda não há políticas públicas suficientes para que essas normas passem a ter eficácia.

Os resíduos sólidos são elementos que devem ser bem tratados e destinados corretamente para que haja um bom saneamento básico, em razão de serem conceitos indissociáveis. A má gestão de saneamento, ou seja, um serviço de disponibilidade de 
água potável e esgotamento sanitário deficitário é um grande problema, principalmente para países subdesenvolvidos e em desenvolvimento. $O$ controle desses fatores é essencial para que o meio físico não exerça potenciais efeitos nocivos sobre o bem-estar físico, mental e social das pessoas (World Health Organization, 2004). Para se ter uma ideia, acredita-se que cerca de dez por cento do volume total de doenças poderia ter sido prevenido pela melhoria das condições de saneamento (World Health Organization; 2008). Estima-se também, que o custo médio de tratamento de doenças relacionadas ao descarte inadequado dos resíduos pode custa US\$ 370 milhões por ano ao sistema de saúde pública do Brasil. (International Solid Waste Association - ISWA, 2015).

Como já supracitado, o descarte inadequado de resíduos representa um impacto na saúde de todos. Todavia, são aqueles que possuem contato direto, os mais afetados, mesmo nos dias atuais. Os garis, catadores e moradores das proximidades dos lixões, apresentam-se como os indivíduos mais vulneráveis, tendo-se em vista a exposição a riscos gravíssimos e irreversíveis, diariamente. O artigo "Catadores de Materiais Recicláveis: Desenvolvimento Tecnológico e Social por Meio de Parcerias" divulga dados coletados pelo grupo de Gestão Ambiental e Desenvolvimento de Empreendimentos Sociais em uma pesquisa realizada para levantar e apontar quais são os maiores problemas operacionais enfrentados por catadores de materiais recicláveis no município de Salvador, e concluiu, que faltam números estatísticos que possam medir a gravidade dos impactos na saúde dessa classe. O artigo ainda contextualiza com alguns outros autores, como Arantes \& Borges (2013) que defende que a saúde dos catadores não é um assunto discutido na literatura hodierna e, destaca ainda, que o excesso do uso da força física, o contato com o lixo e a rotina de tarefas como atividades que influenciam no surgimento de doenças ocupacionais como dores corporais, problemas osteoarticulares e hipertensão. A autora do artigo também cita Hoefel et al. (2013) e afirma que apesar da atividade de catação de resíduos fornecer algum sustento, “...certamente trarão doenças e agravaram as condições de vida dessa população" (p.775). (apud MARCHI e SANTANA, 2018).

Não obstante as influências econômicas, as diferenças de gênero afetam diretamente esse cenário, já que são as mulheres, aquelas inseridas em atividades de menores condições laborais, qualificação e dignidade. Segundo os indicadores sociais, a grande maioria das famílias brasileiras com renda inferior à linha da pobreza é chefiada por mulheres. Para muitas, não há meios de ascensão social por conta das altas taxas de desemprego e machismo, que as obriga, muitas vezes, a cuidarem dos filhos e do lar, 
sozinhas. Desse modo, não há tempo livre e renda para autocuidado e atenção às necessidades do corpo, como se já não bastassem as dificuldades durante as jornadas de trabalho, como idas ao banheiro e para a higiene pessoal, sobretudo quando estão no ciclo menstrual. Por conta dessa subalternização, MATOS (2005) define a pobreza como "essencialmente feminina".

Outra problemática, é a crise mundial do Coronavírus (denominado SARSCOV-2), iniciada em 2019, que obriga os indivíduos a mudarem seus hábitos. A mídia e os órgão públicos divulgam, constantemente, cuidados que os cidadãos devem tomar para evitar contaminação da doença, por meio de medidas de higiene, uso de máscaras, álcool gel, etc. Porém, pouco se fala sobre o descarte adequado dos resíduos domiciliares potencialmente contaminados, nem mesmo quando se trata de indivíduos expostos ao risco, apesar de ser um dos meios mais vulneráveis à propagação do vírus. Essa falta de informação faz com que a desigualdade e a vulnerabilidade dos catadores de resíduos sejam ainda mais intensificadas, nesse momento desafiador, isto é, esses catadores, assim como os médicos, estão na linha de frente, expondo-se, diariamente, a um vírus que pode ser fatal, mas como os catadores são considerados como "invisíveis", no caso de uma possível contaminação, não serão amparados da mesma forma e, possivelmente, não terão um serviço de saúde adequado.

O descarte de resíduos sólidos sempre foi negligenciado no país, devido à falta de consciência da maioria da população quanto a sua separação. Durante a pandemia, consequentemente, não está sendo diferente, na verdade, é um agravante. Silva (2020) salienta a periculosidade associada ao Gerenciamento de Resíduos de Serviços de Saúde nas cidades brasileiras, e exemplifica o descarte inadequado de materiais perfurocortantes e até contaminados, fazendo a reflexão sobre o risco de exposição em comunidades pobres e vulneráveis. E outras pesquisas apontam que as medidas de distanciamento social e a quarentena geraram no país, um aumento de $15 \%$ a $25 \%$ na quantidade de resíduos residenciais (Abrelpe, 2020). A situação, portanto, apresenta-se caótica, devido ao total descaso por parte dos órgãos públicos quanto a esse importante meio de contaminação, colocando a vida da população, sobretudo dos mais vulneráveis, em risco. O presidente da associação do bairro Buritis de Belo Horizonte, Braulio Lara, relata que:

É sempre importante que todas as pessoas tenham cuidados com o condicionamento do lixo doméstico, e principalmente materiais que, eventualmente, podem ter algum tipo de contaminação. Então o correto 
descarte de máscaras, lenços, ou quaisquer outros itens de higiene que, porventura, possam vir a carregar bactérias, vírus, ou qualquer coisa nesse sentido, tem que ser bem condicionado antes de descartado no lixo comum, [...] (JORNAL DAQUI BH, 2020).

O descarte de máscaras, utensílio obrigatório, por se tratar de uma das maneiras mais eficazes na prevenção do vírus, também está sendo negligenciado pelo Poder Público e a sociedade civil. O plástico, matéria prima de boa parte dessas máscaras, é um dos resíduos que mais ameaçam à vida humana, os habitats dos animais e a marinha. O ideal seria que as máscaras fossem descartadas no lixo reciclável e que as cooperativas adotassem medidas preventivas como, por exemplo, deixar os resíduos em isolados e intocáveis por alguns dias. Apesar do cumprimento por muitas empresas, mesmo com todas essas atitudes de precaução e equipamentos de segurança, caso os coletores ou catadores tiverem qualquer tipo de contato com o resíduo contaminado, mesmo que mínimo, com a máscara contaminada e levarem a mão ao rosto, podem ser infectados pelo Covid-19, colocando sua vida e de sua família em risco.

É inegável a enorme influência direta do descarte incorreto de resíduos sólidos na saúde pública por conta da crise do Coronavírus, contudo, esse é um problema crônico no Brasil e no mundo. Os lixões, por exemplo, deveriam ter sido extintos até 2014, de acordo com a PNRS (Brasil, 2010) mas, apesar da diminuição significativa da existência desses ambientes, o objetivo ainda não foi totalmente alcançado. A deposição incorreta dos resíduos, sem nenhuma proteção ao meio ambiente, pode ocasionar danos graves e irreversíveis à saúde da população, e os mais afetados são as famílias que vivem ao redor desse ambiente carente, em condições insalubres e de vulnerabilidade social, por possuírem contato direto com as substâncias tóxicas nocivas ao corpo.

Os lixões são responsáveis pela contaminação do solo pelo chorume (líquido de cor escura proveniente da decomposição da matéria orgânica presente no lixo), mau cheiro e contaminação das águas subterrâneas influenciando, inclusive, na cadeia alimentar e, consequentemente na refeição dos animais e dos seres humanos. Os lixões a céu aberto são de alto risco e também estão relacionados ao aumento de casos de doenças como Dengue, Zika e Chikungunya, como mostra estudos realizados em Minas Gerais:

A incidência de dengue associou-se à gestão de resíduos sólidos e apresentou relação inversa significativa com o percentual de vulneráveis à pobreza. Houve também associação direta o índice de Gini, sugerindo que quanto maiores os registros de incidência de dengue de 2007 a 2016, maiores os valores de Gini dos municípios - ou seja, maior a desigualdade social. A 
cobertura da coleta seletiva apresentou relação inversa e significativa com os casos de dengue, sugerindo que quanto menor a cobertura da coleta de seletiva, maiores foram os casos registrados de dengue. (Mol MPG, Queiroz JTM, Gomes J, Heller L, 2020, p. 3).

O Japão é o país com a maior expectativa de vida no mundo (WHO, 2012) e também é referência no descarte de resíduos. Esses dados evidenciam, justamente, a relação entre uma população saudável, com altos índices de longevidade, sustentabilidade e preocupação com o meio ambiente. Desde muito jovens, ainda no período escolar, as crianças são ensinadas a fazer a separação do próprio resíduo, tendose em vista que não há funcionários nas escolas destinados para essa função. Não obstante, o cuidado quanto à destinação adequada, a sociedade japonesa é igualmente preocupada com a não produção excessiva de resíduos, uma vez que, seu território é um arquipélago pequeno, existe a preocupação quanto à não produção excessiva desses descartes.

O empenho pessoal da população é inquestionável, mas o poder público também faz a sua parte com competência. Os resíduos são recolhidos e levados para os centros de reciclagem e, aqueles que infelizmente são inaproveitáveis, são incinerados. Apesar das inúmeras críticas, trata-se de uma pequena quantidade e é a fonte de energia para residências e área de lazer para a população. A energia gerada é responsável pelo funcionamento de ambientes de lazer, com lojas, centro de ginástica e restaurantes que funcionam com a energia gerada pela queima por esses resíduos, que ainda não são capazes de serem recicláveis. É uma excelente e inovadora iniciativa, já que é um ambiente frequentado principalmente por idosos, assim, aproveita-se o que foi descartado e não pode ser aproveitado, a fim de mantê-los saudáveis.

Nesse sentido, diante de todos os dados e argumentações expostas nesse artigo, evidencia-se a inegável importância em uma melhor gestão dos resíduos sólidos, com o objetivo de garantir uma saúde digna e uma vida longeva com qualidade. O ativismo, a integração e a cooperação entre países, já apresenta resultados positivos, pois são registradas melhorias significativas quanto à redução da mortalidade infantil, na melhoria da saúde materna e na luta contra o HIV/Aids, a tuberculose, a malária e outras doenças. Nos últimos quinze anos, o número de pessoas infectadas pelo HIV anualmente caiu de 3,1 milhões para 2 milhões e mais de 6,2 milhões de vidas foram salvas da malária (ONU, 2015).

Ainda assim, há desafios a serem quebrados visto que, apesar da melhora na saúde e aumento da expectativa de vida da população brasileira, a desigualdade social 
associada a evidente má-gestão ambiental, incluindo o manejo incorreto de resíduos sólidos, pode acarretar danos irreversíveis. Apesar da criação da PNRS (Brasil, 2010), o país ainda deixa muito a desejar em relação a coleta seletiva, destinação correta dos resíduos e, principalmente, amparo aos catadores e garis, heróis invisíveis, os quais são responsáveis pelo gerenciamento dos resíduos e não são reconhecidos ou não existem políticas públicas de inclusão socioeconômica dessa categoria profissional que expõem sua vida e sua saúde, diariamente, contribuindo para a limpeza das cidades.

A legislação, por si só, não é suficiente, é necessária a conscientização da população acerca dos danos que uma má gestão dos resíduos traz à sociedade. A mídia assume papel relevante tanto na formação da opinião pública quanto na funcionalidade do aparelho psíquico e da mentalidade social (Camurra \& Teruya, 2008). Dessa forma, os meios de comunicação devem ser um meio atuante para a proliferação de informação e de incentivo, a fim que a população contribua para um meio ambiente sustentável e destinação correta dos resíduos.

Além disso, os órgãos públicos devem implantar medidas educacionais, ainda no período escolar, para que as crianças aprendam, não apenas a maneira correta de descartar os resíduos, mas também, de como evitar sua produção. As atividades devem ser desenvolvidas de forma prática, como por exemplo, manejo correto dos próprios resíduos, respeitando a coleta seletiva, como também, estratégias da não produção excessiva e desnecessária dos mesmos, além de atividades de artesanato com materiais recicláveis.

É evidente a falta de estudos e artigos sobre o tema, assim é necessária a implantação de atividades de incentivo à pesquisa e extensão nas Universidades que sejam capazes de analisar quais são as grandes problemáticas capazes de afetar a saúde da sociedade, além de compreender os déficits e as demandas daqueles que lidam com os resíduos, como os garis e catadores. Não obstante, é fundamental elencar as condições de trabalho desses brasileiros, a fim que sejam elaboradas soluções eficazes para a violação desses direitos fundamentais. Tudo isso, associado a uma melhor fiscalização para punir aqueles que descumprem a lei, provavelmente, ocasionará numa geração de indivíduos com uma melhor saúde pública e qualidade de vida. 


\section{REFERÊNCIAS}

BRASIL. Constituição (1988). Constituição da República Federativa do Brasil. Brasília, DF: Senado Federal: Centro Gráfico, 1988.

BRASIL, Lei $\mathbf{N}^{\circ} 12.305$ de 02 de agosto de 2010 - Política Nacional de Resíduos Sólidos (PNRS). Disponível em: http://www.planalto.gov.br/ccivil_03/_ato20072010/2010/lei/112305.htm. Acesso em 08 janeiro de 2020.

CAMURRA, L., \& TERUYA,T.K (2008). Televisão, Indústria Cultural e os Desejos infantis: obstáculos à formação do sujeito autonômo. Disponível em: http://www.ppe.uem.br/publicacoes/seminario_ppe_2008/pdf/c010.pdf. Acesso em: 15 de dezembro de 2020.

DAQUI. Os Riscos De Contaminação Por Meio Do Lixo Doméstico. Disponível em:https://www.daquibh.com.br/alerta-os-riscos-de-contaminacao-por-meio-do-lixodomestico/. Acesso em: 9 de novembro de 2020.

EIGENHEER, Vide. A Cidade na História. Belo Horizonte. Niteroi: WMF Martins. 1965.

ESTADÃO. Lixões geram lixo anual de 370 mi para o sistema de saúde. Disponível em: https://ciencia.estadao.com.br/noticias/geral,lixoes-geram-custo-anual-de-us-370milhoes-para-sistema-de-saude,1771302. Acesso em: 9 de novembro de 2020.

ESTADÃO. Quarentena faz Aumentar Coleta de Lixo. Disponível em:https://sustentabilidade.estadao.com.br/noticias/geral,quarentena-faz-aumentarcoleta-delixo,70003345246?fbclid=IwAR30vHYDdyubyIB71dZWDEZG2V9ny_6u8AnM8oNFj qTpZsH2rtCxHeNXyCA. Acesso em: 9 de novembro de 2020.

MARCHI, Cristina Maria Dacach Fernandez \& SANTANA, Joilson. Projetos Sociais e Ambientais para o Fortalecimento dos Empreendimentos Econômicos Solidários de Catadores de Materiais Recicláveis. In: MARCHI, Cristina M. Dacach Fernandez. Gestão dos Resíduos Sólidos: conceitos e perspectivas de atuação. 1. ed., Curitiba: Appris Ltda, 2018. P. 185-198.

MOL, MARCOS PAULO GOMES ET AL. Gestão adequada de resíduos sólidos como fator de proteção na ocorrência da dengue. Disponível em:

$<$ https://doi.org/10.26633/RPSP.2020.22>. Acesso em:10 Novembro 2020.

ORGANIZAÇÃO DAS NAÇÕES UNIDAS. COMMITEE ON ECONOMIC, SOCIAL AND CULTURAL RIGHTS. Disponível em :https://apps.who.int/disasters/repo/13849_files/o/UN_human_rights.htm. Acesso em: 15 de dezembro de 2020.

PLATAFORMA AGENDA 3030. A Agenda 2030 para Desenvolvimento

Sustentável. http://www.agenda2030.org.br/sobre/. Acesso em:9 de novembro de 2020. 
PRUSS-USTUN A, GORE F, BARTRAM J. Safer water, better health: costs, benefits and sustainability of interventions to protect and promote health. Genebra: World Health Organization ; 2008.

SILVA, A, C, N. 2014. Resíduos de serviços de saúde \& saúde pública - conceitos, regulamentação e tratamento prévio. Salvador: Editora EDUFBA, 2014 (modo de acesso: https://repositorio.ufba.br/ri/handle/ri/17157).

Silva, A, C, N. (2020). Lava e fica bom: catadores reaproveitam material durante pandemia. In Correio da Bahia, 2020. Disponível em:

https://www.correio24horas.com.br/noticia/nid/lava-e-fica-bom-catadoresreaproveitam-materiais-contaminados-durante-pandemia/\#>. Acesso em: 27 junho 2020.

SOUZA, GISELE FERREIRA ET AL. Prevalência e fatores associados a doenças respiratórias e diarreia em trabalhadores de cooperativas de materiais recicláveis da cidade de São Paulo. Disponível em: <https://doi.org/10.5123/S167949742020000300022>.Acesso em: 5 Dezembro 2020.

WORLD HEALTH ORGANIZATION. Constituição da Organização Mundial da Saúde. Disponível em:http://www.direitoshumanos.usp.br/index.php/OMSOrganiza\%C3\%A7\%C3\%A3o-Mundial-da-Sa\%C3\%BAde/constituicao-daorganizacao-mundial-da-saude-omswho.html. Acesso em: 9 de novembro de 2020.

WORLD HEALTH ORGANIZATION. Ottawa Charter Health Promotion First International Conference Health Promotion. Disponível em: https://www.afro.who.int/publications/ottawa-charter-health-promotion-firstinternational-conference-health-promotion. Acesso em: 9 de novembro de 2020.

WORLD HEALTH ORGANIZATION. Life expectancy data by country. Disponível em: https://apps.who.int/gho/data/node.main.688?lang=en. Acesso em: 9 de novembro de 2020. 


\section{III}

\section{O CONSUMO E A SOCIEDADE CONTEMPORÂNEA: DESAFIOS DA ADMINISTRAÇÃO PÚBLICA NA GESTÃO DO CONSUMO CONSCIENTE}

As buscas incansáveis por desenvolvimento de novas tecnologias são frutos de uma sociedade que tem como base o consumo excessivo e com novas exigências de mercados.

Sendo assim, novos produtos são criados, fato que leva as empresas a usar de mecanismos e de expedientes que nem sempre são parceiros do meio ambiente, no entanto é uma realidade que pode ser modificada com a inserção e com o uso de critérios ambientais impostos pelo poder público.

Diante do novo contexto ambiental e, em outro ponto, a sustentabilidade, a educação ambiental e o marketing verde ganharam relevo no cenário nacional, tendo em vista o acesso à informação e à preocupação social em se fazer campanhas publicitárias de caráter preventivo e, por vezes, de caráter repressivo ao mau uso do meio ambiente.

Em decorrência da sua capacidade de suporte (ANTUNES, 2012), o meio ambiente vem dando sinais evidentes de resposta à degradação. Isso por força de um capitalismo agregado a uma revolução industrial sem limites onde o meio ambiente foi o maior prejudicado, tendo em vista que, naquele momento, não eram levadas em consideração as questões ambientais, sendo relevante àquela época o desenvolvimento econômico, e o meio ambiente não tinha espaço pois as pessoas não tinham qualquer tipo de preocupação ambiental.

\footnotetext{
${ }^{8}$ Advogado especialista em Direito Ambiental Corporativo. Sócio do Escritório André Medeiros. Mestre em Planejamento Ambiental pela Universidade Católica de Salvador. Especialista em Processo Civil pela Unifacs. Especialista em Direito Público do Estado pela Unyahna Professor titular da Unijorge na graduação de Direito. Professor da Escola de Magistratura do Estado da Bahia - EMAB. Professor de Direito Ambiental do Centro de Estudos José Aras. Professor de Direito Ambiental do Brasil Jurídico e do CP Iuris. Autor de diversas obras jurídicas. E-mail: rssvaz@gmail.com
} 
Ideais de utilização de produtos ambientalmente corretos são evidentes na sociedade. Contudo, o poder público precisa fazer uma mutação na exigência de produtos e de serviços no momento de sua aquisição, tendo como auge o meio ambiente, evitando assim o consumo de produtos que causem degradação ambiental, mudando, consequentemente, o estereótipo do consumidor, que passa a se preocupar com questõescomo a da industrialização do produto.

\section{SUSTENTABILIDADE E A CONSTITUIÇÃO FEDERAL DE 1988}

Tamanha é a preocupação do legislador constitucional com o meio ambiente que, em 1988, tratou de inserir no rol dos seus artigos a proteção ambiental, materializada no artigo 225. No entanto, palavras como sustentabilidade e desenvolvimento sustentável foram inseridas na Constituição Federal com o intuito de garantir um bem maior que não vemos, mas de que precisamos, que é a proteção ambiental e, indiretamente, um direito à vida, princípio este garantido, de forma expressa, no seu artigo $5^{\circ 9}$.

Por força da importância da temática em garantir a qualidade ambiental assim como o direito à vida, é que meios de proteção ambiental são de total importância tendo em vista o destaque de garantia do meio ambiente ecologicamente equilibrado, inclusive dos seres que ainda não nasceram. Assim sendo, faz-se um apanhado histórico de degradação ambiental e, dada a importância da garantia fundamental à vida e da proteção ambiental, têm-se, como via de consequência, as tomadas de decisão feitas pelos gestores de políticas públicas, que precisam ser amparadas levando em consideração o meio ambiente, e tendo, como instrumento para a efetivação dessas políticas públicas, ambientais a inserção de critérios ambientais nas licitações públicas.

A ideia central deste estudo é fazer uma revisão teórica na Lei Federal notadamente, no tocante, o comportamento da sociedade consumir, tendo como marco ensejador dessa modificação a Administração Pública e, posteriormente, o consumidor final, conforme afirma Portilho:

Isto exige uma revisão teórica de mão-dupla, ou seja, uma revisão das

Teorias de Consumo e da Sociedade de Consumo à luz da questão ambiental

\footnotetext{
${ }^{9}$ Art. $5^{\circ}$ Todos são iguais perante a lei, sem distinção de qualquer natureza, garantindo-se aos brasileiros e aos estrangeiros residentes no País a inviolabilidade do direito à vida(...). (BRASIL, Constituição Federal, 1988) (Destaque Nossos).
} 
e uma revisão da questão ambiental à luz das teorias da Sociedade de Consumo. (PORTILHO, 2010, p. 37/38)

Por conseguinte, após uma breve explanação dos pontos importantes para uma evolução dos direito relativos ao direito ambiental, o primeiro passo para implementação de uma sociedade sustentável deverá ser uma mudança na forma de se pensar quando se está tratando do meio ambiente. A evolução da sociedade vem alterando a forma de consumir, especialmente que os produtos eram comprados e rotulados como "bens duráveis", enquanto que nos dias atuais tais produtos são bens descartáveis (adquiridos com prazo de validade).

\section{O CONSUMO SUSTENTÁVEL NA SOCIEDADE CONTEMPORÂNEA}

O conceito doutrinário de consumo sustentável passa por algumas modificações a depender da legislação pátria de cada país, devendo seguir a ideia central extraída do guia $^{10}$ internacional que foi elaborado pela Organizações das Nações Unidas (ONU), o qual salienta a importância do meio ambiente que se torna o centro da questão, tendo o conceito de consumo sustentável de grande valia social, necessitando, contudo, ser observados alguns pontos importantes no ciclo da vida do produto, sempre pautado na preocupação de não comprometer o meio ambiente para as futuras gerações.

Ao direcionar o tema e ao conceituar o consumo sustentável, o guia coloca em evidência a melhoria da qualidade ambiental, que tem como ideia central a necessidade básica de valer-se do uso de produtos que sejam ambientalmente corretos visando uma melhor qualidade de vida, através de meios idôneos, para a sua inserção na comunidade $^{11}$, e via de consequência atendendo os preceitos constitucionais de manutenção do meio ambiente equilibrado para as presentes e futuras gerações.

No mesmo passo que se chega ao conceito geral de consumo sustentável, quando iniciou-se uma interação entre o desenvolvimento sustentável e uma nova forma de se consumir, na qual estaria pautadas questões ligadas ao direito a informação do

\footnotetext{
10 "Hands-on Sustainable Consumption: A training guide for implementing the United Nations Guidelines for Consumer Protection"

${ }^{11}$ Consumo sustentável é "o uso de serviços e produtos relacionados que respondem às necessidades básicas e trazem uma melhor qualidade de vida, enquanto minimiza o uso de recursos naturais e materiais tóxicos, bem como a emissão de resíduos e poluentes ao longo do ciclo de vida de modo a não comprometer as necessidades das futuras gerações. (Hands-on Sustainable Consumption: A training guide for implementing the United Nations Guidelines for Consumer Protection, 2013). (Tradução nossa)
} 
ciclo do produto e ao chamado marketing verde. ${ }^{12}$ A sociedade atual busca as informações inerentes ao produtos e/ou serviços que são consumidos, forçando os fornecedores a terem nos seus fluxos de produção uma melhor adequação as questões ambientais.

\subsection{CONSUMO SUSTENTÁVEL E APLICAÇÃO DO DIREITO DO CONSUMIDOR FRENTE A ADMINISTRAÇÃO PÚBLICA}

Estabelecidas as primeiras premissas inerentes ao conceito de consumidor, acrescente-se, também, a contribuição na sobredita definição sob o prisma mundial, apresentando as seguintes definições:

Defesa do Consumidor é:

- lutar contra as irregularidades do mercado que impactaram negativamente nos mercados e ao consumidor;

- responsabilizar o consumidor a fazer escolhas informadas e selecionar bens de valor para o dinheiro;

- proporcionar o acesso justo a bens e serviços básicos;

- abrir caminhos para resolver os interesses do consumidor e preocupações.

(Hands-on Sustainable Consumption: A training guide for implementing the United Nations Guidelines for Consumer Protection, 2013) (Tradução do autor)

Aspecto de extrema relevância é conceituar o consumidor, pois com a evolução social esse conceito vem ganhando novas diretrizes. Ou seja, o primeiro critério a ser observado pela sociedade são as irregularidades do mercado, quando o mercado não trata de forma igual ou desigual, aqueles que atendem e os que não atendem as questões ambientais.

Deve ser destacado que por força constitucional o poder público pode intervir nas relações consumeristas e ambientais, especialmente na imposição de regras que visem trazer uma melhor condição social.

\footnotetext{
${ }^{12}$ Consumo sustentável é um passo fundamental para alcançar o desenvolvimento sustentável. A relação intrínseca entre o consumo sustentável e do paradigma do desenvolvimento sustentável foi sublinhado na Declaração de Joanesburgo sobre Desenvolvimento Sustentável, que afirma que: "a pobreza erradicação, mudando padrões de consumo e produção e a proteção e gestão do natural base de recursos para o desenvolvimento econômico e social são objetivos fundamentais e essenciais requisitos para o desenvolvimento sustentável". Desde a Conferência de 1972 das Nações Unidas sobre o Meio Ambiente Humano, em Estocolmo, a comunidade internacional junta-se para desenvolver acordos centrados em questões ambientais e de desenvolvimento. A ONU estabeleceu diretrizes para a Proteção do Consumidor em um desses acordos. (Hands-on Sustainable Consumption: A training guide for implementing the United Nations Guidelines for Consumer Protection, 2013) (Tradução nossa)
} 
Sob o prisma do poder público, a Administração Pública é a detentora do dinheiro público, devendo justificar o emprego do dinheiro público, isto significa dizer que é obrigação da Administração pública impor regras e procedimentos para um consumo mais sustentável, especialmente na imposição de regras que contemplem o uso de produtos que estejam realmente em consonância com os critérios ambientais.

Assim como novos instrumentos, devem ser implementados tais como: consumo sustentável ${ }^{13}$, educação ambiental e o marketing verde. Nota-se, então, uma evidente mudança na forma de comportamento do consumidor frente ao cenário ambiental.Devese considerar, além dos aspectos financeiros, a produção e a imagem do produto ligadas ao meio ambiente, ao mesmo tempo em que essa nova consideração também seja aderida pelos empresários, no momento da produção e elaboração dos seus produtos, afastando ideais basilares do marketing que é a busca somente do lucro.

Sob essa mesma perspectiva deverá se ter como ponto forte no que se refere à nova forma de consumir Estatal, a qual deverá ser imposta pelos entes públicos, tendo em vista a sua compra em "Atacado"14 modificando a forma para a das compras em "Varejo"15 feitas pelos consumidores finais, fomentando o Estado a uma nova mudança na sua forma de consumir.

Assim, o Governo busca mudanças seja nas suas políticas ambientais como também na sua forma de consumir, não obstante tal direcionamento Estatal em que foi criado o Plano de Ação para a Produção e Consumo Sustentável ditando diretrizes gerais para a mudança de padrões de consumo, conforme veremos:

O Plano articula as principais políticas ambientais e de desenvolvimento do País, em especial as Políticas Nacionais de Mudança do Clima e de Resíduos

\footnotetext{
${ }^{13}$ Consumo Sustentável é: - Atender às crescentes necessidades das pessoas com melhores resultados ambientais e mais consumo sustentável utilizando menos recursos e causando menos poluição para permitir o desenvolvimento humano em todas as partes do mundo; • Ajudar os consumidores a estimular os fornecedores a ser inovadores, melhorar a competitividade e promover a crescimento econômico e o desenvolvimento. (Hands-on Sustainable Consumption: A training guide for implementing the United Nations Guidelines for Consumer Protection, 2013) (Tradução nossa Tradução do autor. (Destaque do mesmo).

14 Significado da palavra no dicionário Michaeles disponível no site: http://michaelis.uol.com.br/moderno/portugues/index.php?lingua=portugues-portugues\&palavra=atacado 1 Apertado, preso ou unido com ataca ou atacador. 2 Cheio até em cima; abarrotado, carregado. sm Com Forma de venda em grosso. $3 \mathrm{sm}$ Econ Comércio em grande escala, realizado entre produtores e revendedores, que se encarregam de fazer chegar o produto aos consumidores finais. Antôn: varejo. Acesso em 21.abr.2014.

15 Significado da palavra no dicionário Michaeles disponível no site < http://michaelis.uol.com.br/moderno/portugues/index.php?lingua=portugues-portugues\&palavra=varejo > (ê) $\mathrm{sm}$ (der regressiva de varejar) 1 Ato ou efeito de varejar; varejadura, varejamento. $2 \mathrm{~V}$ varejamento. 3 Fogo de fuzilaria ou de artilharia; surriada. 4 Censura, correção, repreensão áspera, reprimenda. 5 Venda a retalho ou por miúdo. A varejo: a retalho, por miúdo. Acesso em 21.abr.2014.
} 
Sólidos e o plano Brasil Maior, auxiliando no alcance de suas metas por meio de práticas produtivas sustentáveis e da adesão do consumidor a este movimento. (MINISTÉRIO DO MEIO AMBIENTE, 2014, p.1).

Na mesma senda, o Hands-on Sustainable Consumption também estabelece critérios ambientais e mudanças nos padrões de consumo, o qual informa que o Governo tem um papel de extrema importância ao desempenhar o desenvolvimento nos padrões de consumo, sendo um interventor de relevo no ordenamento. Inicialmente, ao informar o consumidor sobre as suas compras e também por poder implementar nas suas compras serviços e produtos que sejam ambientalmente corretos, preservando recursos como ar e água de uma degradação efetiva. ${ }^{16}$

Outro pilar é que o poder público tem que fundamentar as suas escolhas ao trazer a informação de forma clara à sociedade, fazendo com que seja efetivado o estado democrático de direito e fazendo com que a Administração Pública tenha uma nova forma de consumir sem levar críticas.

Interessante frisar a importância do consumo feito pela Administração Pública, quando atrelado ao consumo sustentável e, quanto à defesa do consumidor, o que deverá ser observado sob uma lente ambiental, mudando, de forma evidente, os conceitos usados pelo marketing tradicional, levando em consideração ainda o Plano de Ação para a produção e Consumo Sustentável (PPCS), o mesmo elenca como princípio básico de que a mudança deverá ser gradativa, conforme veremos:

O PPCS é um plano dinâmico, vivo, e que deve ser apropriado pela sociedade em geral. Sua implementação será progressiva, refletindo os avanços em

\footnotetext{
${ }^{16}$ Os governos têm um papel fundamental a desempenhar na iniciação, desenvolvimento e avaliação de uma mudança no consumo padrão. Eles são responsáveis por fornecer aos consumidores de bens de consumo e serviços com as ferramentas necessárias para fazer escolhas conscientes e sustentáveis. $\mathrm{O}$ impacto total do consumo das famílias é um contribuinte importante para um certo número de problemas ambientais, incluindo a poluição do ar e da água, e mudanças climáticas. Há pouca informação disponível sobre o custo-efetividade dos instrumentos de informação para ajudar as famílias a reduzir seus impactos ambientais. Garantir informações precisas e confiáveis no mercado e priorização de estratégias públicas de informação ambiental será importante na redução do dispêndio de tempo e recursos exigidos das famílias para adotar um consumo mais sustentável patterns. Fornecendo informações precisas ao consumidor é também uma questão de valores democráticos. Especificamente "é um direito fundamental dos cidadãos numa democracia que funcione bem para saber o que os funcionários públicos estão fazendo. Quando ao público é permitido para compreender o desenvolvimento de uma política, então é mais fácil para governo construir o apoio para a sua aplicação e concretização dos objetivos subjacentes." (Destaque do tradutor) Para este fim, altamente desenvolvidos programas de informação do consumidor focados pode ajudar os governos a adotar políticas e métodos que irão promover o consumo sustentável. Há um certo número de estratégias de sucesso responder a crescente ceticismo do consumidor ter percebido "sobrecarga de informação" e para a escolha e concepção de instrumentos para a sua entrega. (Hands-on Sustainable Consumption: A training guide for implementing the United Nations Guidelines for Consumer Protection, 2013) (Tradução nossa Tradução do autor. (Destaque do mesmo)
} 
outras políticas públicas e o amadurecimento da sociedade brasileira. (MINISTÉRIO DO MEIO AMBIENTE, 2014, p.1).

A proposta então encartada no programa não são ações de cunho radical e sim de cunho paulatino em que se deverá observar as necessidades da sociedade e as políticas ambientais impostas para a referida sociedade gerando um impacto direto na forma de se consumir.

O Supremo Tribunal Federal (STF) já firmou entendimento sobre o consumo de produtos que não sejam nas diretrizes traçadas pela Constituição Federal e pelas leis que visam a promoção da proteção ambiental ao julgar a Arguição Descumprimento de Preceito Fundamental (ADPF), número $101^{17}$, proveniente do Distrito Federal, quanto enfrentou aspectos constitucionais sobre o licenciamento ambiental.

Doravante o entendimento do STF, a situação revela-se como paradigma para justificar a importância do atendimento ao Desenvolvimento Sustentável e da garantia dos direitos ao meio ambiente ecologicamente equilibrado para as presentes e futuras gerações. Em suma, a necessidade de imposição de normas e procedimento para a busca de um consumo sustentável que atenda as exigências da sociedade atual.

Do resultado do julgamento cabem algumas conclusões importantes, tais como a preocupação do STF em delimitar e conceituar, de forma cristalina, o desenvolvimento

\footnotetext{
${ }^{17}$ ADPF $101 /$ DF

1. Adequação da arguição pela correta indicação de preceitos fundamentais atingidos, a saber, o direito à saúde, direito ao meio ambiente ecologicamente equilibrado (arts. 196 e 225 da Constituição Brasileira) e a busca de desenvolvimento econômico sustentável. (...) Crescente aumento da frota de veículos no mundo a acarretar também aumento de pneus novos e, consequentemente, necessidade de sua substituição em decorrência do seu desgaste. Necessidade de destinação ecologicamente correta dos pneus usados para submissão dos procedimentos às normas constitucionais e legais vigentes. Ausência de eliminação total dos efeitos nocivos da destinação dos pneus usados, com malefícios ao meio ambiente: demonstração pelos dados. 4. Princípios constitucionais (art. 225) a) do desenvolvimento sustentável e b) da equidade e responsabilidade intergeracional. Meio ambiente ecologicamente equilibrado: preservação para a geração atual e para as gerações futuras. Desenvolvimento sustentável: crescimento econômico com garantia paralela e superiormente respeitada da saúde da populacão, cujos direitos devem ser observados em face das necessidades atuais e daquelas previsíveis e a serem prevenidas para garantia e respeito às geracõos futuras. Atendimento ao princípio da precaucão, acolhido constitucionalmente, harmonizado com os demais princípios da ordem social e econômica. (...) Ponderação dos princípios constitucionais: demonstracão de que a importação de pneus usados ou remoldados afronta os preceitos constitucionais de saúde e do meio ambiente ecologicamente equilibrado (arts. 170, inc. I e VI e seu parágrafo único, 196 e 225 da Constituição do Brasil). (...) Vistos, relatados e discutidos estes autos, acordam os Ministros do Supremo Tribunal Federal, em Sessão Plenária, sob a Presidência do Ministro Gilmar Mendes, na conformidade da ata de julgamento e das notas taquigráficas, preliminarmente, por maioria, em conhecer a argüição de descumprimento de preceito fundamental, e, no mérito, por maioria, em dar parcial provimento à argüição de descumprimento de preceito fundamental, nos termos do voto da Relatora. Ausentes, neste julgamento, o Senhor Ministro Cezar Peluso e, licenciado, o Senhor Ministro Menezes. Direito. Brasília, 24 de junho de 2009. Ministra CÁRMEN LÚCIA - Relatora (Grifos deste mestrando) (IDEM)
} 
sustentável. Outro ponto, a preocupação em harmonizar o sobredito desenvolvimento sustentável com a ordem social e a ordem econômica e tendo como pano de fundo a efetivação do princípio da precaução, buscando, assim, a efetividade do comando constitucional expresso no artigo 225.

Por fim, a mudança de paradigmas com o julgamento do STF faz crescer a corrente de que os princípios ambientais devem estar no centro das questões, assim como se deve mudar a forma de consumo, quando se deverá buscar uma ordem social ambiental e não somente o crescimento econômico.

\subsection{A VIDA EM SOCIEDADE, O CONSUMO SUSTENTÁVEL E A PROTEÇÃO AMBIENTAL}

A preocupação do homem se direciona ao seu redor ao ver a vida em sociedade, e procurando meios para uma sociedade sustentável sendo uma condição sine qua non para a manutenção da vida na terra. Assim, o que deve ser reestruturado é o pensamento e, por consequência, sua forma de agir na vida em sociedade, em vista de momentos marcantes e importantes para o reflexo ambiental, a saber, a busca do desenvolvimento e crescimento econômico, fruto da essência do que é preconizado pelo capitalismo, sem levar em consideração os aspectos ambientais.

Nesse mesmo sentido e debruçando-se nos ensinamentos de Portilho, devem ser destacadas:

\footnotetext{
As ações individuais no campo das escolhas de consumo têm sido vistas, por uma série de autores, instituições governamentais, não governamentais e empresariais, principalmente dos países centrais, como uma boa estratégia de mudanças em direção a uma sociedade sustentável. (PORTILHO, 2010, p. 56)
}

A proposta de consumo novamente passou por uma evolução de um modelo que era voltado para um contrato social, situação proposta por Rousseau na sua obra Contrato Social, em que o homem vive em sociedade e deriva as suas relações por meio de um contrato, ou melhor, as regras de convivência decorrem de anseios e de vontade da própria sociedade que imputa a cada indivíduo contratos "tácitos".

Não são observados os aspectos ambientais, ao se analisar o mundo hoje, em decorrência de que o homem continua a fazer "contratos", porém estes de "consumo", e levando a sociedade a uma degradação ambiental maior. 
DEMOCRACIA AMBIENTAL E SOCIEDADE AMBIENTAL

Para se tentar mudar a sociedade atual, faz-se necessário analisar duas questões preambulares: a democracia ambiental e a educação ambiental. A primeira deve ser entendida como uma forma de acesso ao meio ambiente equilibrado a todas as pessoas, inclusive sendo lastro do caput do artigo 225 da Constituição Federal de 1988, que trata da questão como sendo "Todos" ${ }^{18}$, ou seja, sem fazer qualquer distinção, seja ela qual for. E, quanto à Educação, Ambiental, é um mecanismo importante na nova concepção ambiental com a entrada de elementos que conscientizam a população.

Cabe olvidar os ensinamentos de José Afonso da Silva, ao tratar das questões de qualidade ambiental, quando prescreve:

A qualidade do meio ambiente transforma-se, assim, num bem ou patrimônio, cuja preservação, recuperação ou revitalização se tornaram um imperativo do Poder Público, para assegurar a boa qualidade de vida, que implica em boas condições de trabalho, lazer, educação, saúde, segurança enfim boas condições de bem-estar do Homem e de seu desenvolvimento. (SILVA, 2013, p. 25)

Além da previsão constitucional, o Conselho Nacional de Justiça (CNJ), por intermédio da sua recomendação $\mathrm{n}^{\circ} 11$, recomenda que os Tribunais adotem políticas públicas para a manutenção do meio ambiente ecologicamente equilibrado. Traz, no seu bojo, a implementação de produtos que sejam de acordo com o meio ambiente, a exemplo da utilização de papel reciclado e não clorado nos impressos do Poder Judiciário, sejam de natureza administrativa ou processual; outro ponto que é bastante salutar é a instituição da coleta seletiva de resíduos, destinando recipientes individuais para plástico, papel, metal e vidro, e a ulterior doação do material coletado a entidades assistenciais que se responsabilizem pela correta utilização do material para a devida reciclagem.

Outros bons exemplos implementados são a aquisição de impressoras que imprimam, automaticamente, em frente e verso, assim como a aquisição de bens e materiais de consumo que levem em consideração o tripé básico da sustentabilidade: ambientalmente correto, socialmente justo e economicamente viável.

18 BRASIL. Constituição da Republica Federativa do Brasil. Disponível em: http://www.planalto.gov.br/ccivil_03/constituicao/constituicao.htm. Acesso em: 10 out 2013. 
Notória é a preocupação também do órgão que fiscaliza o Poder Judiciário em preocupa-se com as questões ambientais, tecendo a fundo nas suas recomendações meios que tenham como objetivo reduzir ou minimizar os impactos ambientais.

Portanto, a população para ter um novo pensamento requer como eixo primordial uma boa informação e uma boa gestão ambiental, notadamente em razão de implementações de normas e diretrizes que visem uma diminuição nos impactos ambientais.

\section{CONSIDERAÇÕES FINAIS}

A concepção da vida ambiental e a busca da vida sustentável vêm ganhando novos adeptos a cada dia, seja com a inserção de novos produtos ou de novas práticas esportivas. Inicialmente, o pensamento que predominava no mundo era aquele voltado ao crescimento econômico a qualquer custo. Atualmente, o cenário muda de figura e passa a levar em consideração os aspectos ambientais, resultando em uma nova forma de consumir, e, em consequência, a busca do desenvolvimento sustentável.

A percepção atual necessita de uma quebra de paradigmas e de conceitos antes impostos como regras que limitavam o ordenamento, em razão de uma nova concepção do meio ambiente, passando por uma 'mutação' ambiental.

A repactuação deve ser entendida com a inserção de critérios ambientais nas licitações públicas, gerando uma nova forma de se consumir e, consequentemente, uma nova forma de se utilizar o meio ambiente efetivando direitos e garantias já expostos. Dessa forma, o poder público tem o dever de inserir novos critérios e de derrubar paradigmas para a construção de uma nova sociedade.

Uma nova ordem ambiental deve ser implementada trazendo uma nova recomposição por meio do meio ambiente como mais um elemento nas condições de vida em sociedade, dito de outras palavras, o poder público necessita incluir produtos que preservem o meio ambiente.

A partir dessa ideia de mudança e de sobreposição da esfera privada pela pública, é ocasionada uma cultura política direcionada para o enfoque ambiental, em que a sociedade se volta ao meio ambiente, e este se torna o tema central por força de aspectos de consciência e de proteção que vêm evoluindo ano após ano. 
É a partir de mudanças de pensamento e de atitudes que se faz com que essa nova consciência ambiental seja imposta para uma nova reorganização ambiental e sejam levados em consideração alguns aspectos, sofrendo, assim, uma mutação para um mundo verde.

\section{REFERÊNCIAS}

ANTUNES, Paulo de Bessa. Direito ambiental. 14. ed. Rio de Janeiro: Atlas, 2012.

ANTUNES, Paulo de Bessa. Política Nacional do Meio Ambiente - PNMA:

Comentários à Lei 6.938, de 31 de agosto de 1981. Rio de Janeiro: Lumen Juris, 2005.

Hands-on Sustainable Consumption: A training guide for implementing the United Nations Guidelines for Consumer Protection. Disponível em: http://www.consumersinternational.org/media/316122/handson $\% 20$ sustainable $\% 20$ consumption-

$\% 20$ implementing\%20sustainable\%20consumption\%20policies.pdf. Acesso em: 01 out. 2020.

FIORILlO, Celso Antônio Pacheco. Curso de Direito Ambiental Brasileiro. 14. ed. ver. Ampl. em face da Rio +20 e do novo "Código Florestal”. São Paulo: Saraiva, 2013 6. ed. São Paulo: Saraiva, 2005.

FREITAS, Juarez. Sustentabilidade: Direito ao Futuro. Belo Horizonte: Fórum, 2011.

FRANCIOLI, Priscila Alves Pereira. O Direito Ambiental na Sociedade de Risco. Disponível em: www.revistagrupointegrado.br. Acesso em: 20 dez. 2006.

MACHADO, Paulo Affonso de Leme. Direito Ambiental Brasileiro. 11. ed. São Paulo: Malheiros, 2003.

MEIRELLES, Hely Lopes. Direito Administrativo. 26a ed. Atual., São Paulo. Malheiros Editores, 2001.

MINISTÉRIO DO MEIO AMBIENTE. Disponível em: http://www.mma.gov.br/responsabilidade-socioambiental/producao-e-consumosustentavel/plano-nacional. Acesso em: 22 jun. 2014.

ORGANIZAÇÃO DAS NAÇÕES UNIDAS. Declaração de Estocolmo sobre o Ambiente Humano (Declaração de Estocolmo), adotada de 5 a 16 de junho de 1972. Disponível em: http://www.onu.org.br/rio20/img/2012/01/rio92.pdf. Acesso em: 24 abr. 2013.

PORTILHO, Fátima. Sustentabilidade Ambiental, consumo e cidadania. $2^{\text {a }}$ ed.. São Paulo: Cortez, 2010. 


\title{
RESÍDUOS SÓLIDOS EM UMA SOCIEDADE DECONSUMO
}

À luz da máxima que vivemos numa sociedade consumista, percebe-se que vivemos também numa sociedade de desperdícios uma vez que consumo não é o que se compra, mas o que se gasta na busca para satisfazer as necessidades, sem pensar nos impactos gerados pelo processo produtivo dessa satisfação.

Bauman (2001) afirma que, anteriormente, o consumo tinha o propósito de satisfazer as necessidades biológicas e sociais de sobrevivência dos indivíduos e deixava de ser relevante no momento em que as necessidades eram satisfeitas. Mas na atualidade o consumo é automotor, sendo o propósito da sociedade, que proclama a impossibilidade de satisfação das necessidades e a continuidade do estado de tensão, na busca de satisfazê-las.

O consumo se faz presente no decorrer da história da sociedade humana, mostrando-se como base de crescimento, como exemplifica Vargas (2015, p. 3):

\begin{abstract}
Primeiramente era consumo de sobrevivência, colhendo, caçando, pescando, apenas aquilo que era necessário para a manutenção da vida. Com os avanços tecnológicos, a invenção da moeda como ordenação do mercado, a Revolução Industrial, o consumo foi se modificando até se tornar mandatário do crescimento econômico, sendo baseado em necessidades utópicas, na busca pela felicidade universal.
\end{abstract}

Ao fim da Segunda Guerra Mundial, os Estados Unidos possuíam uma enorme capacidade industrial que necessitava ser mantida em funcionamento, então, no ano de 1955, o economista e analista de vendas norte-americano Victor Lebow redigiu o enunciado que rege a sociedade de consumo até os dias de hoje:

\footnotetext{
${ }^{19}$ Engenheira Ambiental e Sanitarista, pós-graduanda em Gestão de Resíduos Sólidos Socialmente Integrados (UFBA). E-mail: lari.medasi@gmail.com
} 
Nossa economia enormemente produtiva exige que façamos do consumo o nosso modo de vida, que transformemos a compra e uso de bens em rituais, que busquemos a nossa satisfação espiritual e do nosso ego no consumo. Nós precisamos que as coisas sejam consumidas, gastas, substituídas e descartadas em um ritmo cada vez mais acelerado. (LEBOW, 1955, p. 3)

Corrêa (2011) destaca que somos o reflexo de um modelo que foi alegremente adotado por uma sociedade feliz, com o tempo de paz e prosperidade que estavam vivendo após segunda guerra e que foi amplamente difundido, para o restante do mundo através da indústria cultural.

\section{PROBLEMÁTICA DE RESÍDUOS SÓLIDOS NA SOCIEDADE DE CONSUMO}

Sabemos que estamos inseridos em um sistema econômico capitalista, cuja finalidade é o lucro independente dos setores de atuação. Desse modo, caminhamos sobre uma tríade indissociável, pautada, essencialmente, nos processos de produção, comércio e consumo, que, desde os primórdios da humanidade, vem estabelecendo estreitas relações (SOUZA, 2019).

Severiano (2017) aponta que a sociedade e a cultura do consumo estão além dos produtos ou serviços produzidos pelo capitalismo. De fato, o consumo estende-se para a produção de signos marcadores de subjetividades, que prescrevem modos de ser, de pensar e de sentir. Nele, são operados mecanismos de socialização, de exclusão e de inclusão social, tendo em vista o lugar de reconhecimento intersubjetivo que ele promove.

Com os adventos tecnológicos, passaram a ocorrer rápidas transformações de valores e de costumes que implicam em mudanças sociais. Aspectos culturais tiveram suas validades encurtadas de modo que as mudanças processuais em gerações diferentes, agora acontecem rapidamente dentro de uma mesma geração, exigindo atualizações constantes das pessoas inseridas neste contexto (ROSA, 2003).

No famoso documentário sobre a história das coisas, LEONARD (2007) ilustra o sistema linear de produção adotado pela sociedade consumista como: extração > produção > distribuição > consumo > descarte. Esse sistema de produção linear interage com culturas, ambientes, sociedades e economias, além de pessoas. Entende-se que cada indivíduo social influencia o sistema conforme seus interesses, e estes podem ser diversos. 
Para manter este sistema linear em crescimento constante, além da expansão do formato para novos mercados, era preciso um incremento de vendas já existentes, o que gerou o desenvolvimento de técnicas de incentivo ao consumo, com bases tanto na própria concepção dos produtos (obsolescência técnica e programada) quanto nos hábitos dos consumidores (obsolescência percebida). (CORRÊA, 2011; LEONARD, 2007).

Assim, durante as etapas produtivas, esse sistema choca-se com limites: a) $\mathrm{Na}$ etapa de extração, tem-se a esgotabilidade dos recursos naturais em função da exploração massiva dos mesmos; b) Durante a produção, tem-se a geração de resíduos sólidos e efluentes líquidos, além da liberação de poluentes, provenientes dos produtos químicos e reagentes adicionados aos recursos naturais na cadeia produtiva; c) A distribuição apresenta limitações logísticas no transporte e comércio dos produtos e precarização da mão de obra; d) $\mathrm{O}$ descarte dos produtos pela necessidade de substituição contínua dos mesmos implica em poluição do ar, do solo e da água, produção de poluentes e a velocidade com que acontece afeta a capacidade do planeta em decompor e reincorporar esses materiais. Logo, não se pode gerir um sistema linear indefinidamente num planeta finito (LEONARD, 2007).

Até a década de 1970 a crise ambiental era atribuída ao crescimento demográfico, principalmente nas nações em desenvolvimento. Durante a Conferência de Estocolmo de 1972, explicitou-se que o ritmo de produção dos países industrializados provocava grande pressão sobre os recursos naturais do planeta; enquanto que a Conferência Rio-92 marcou a mudança de perspectiva acerca da crise, vinculando produção e consumo. (SOUZA, 2019)

Em 2015, os países-membros da ONU (Organização das Nações Unidas) aprovaram o documento "Transformando o Nosso Mundo: A Agenda 2030 para o Desenvolvimento Sustentável", que trazem 169 metas dos 17 Objetivos de Desenvolvimento Sustentável. Sendo de natureza global e universalmente aplicáveis, essas metas são integradas e indivisíveis tendo em conta diferentes realidades, capacidades e níveis de desenvolvimento nacional. Reconhece-se que cada país enfrenta desafios específicos mas todos os atores envolvidos na implementação das metas são encorajados a ultrapassar o mínimo exigido para a realização de uma meta. (PNUD, 2019) 
O Objetivo de Desenvolvimento Sustentável 12 é "Consumo e produção responsáveis", então mudança nos padrões de consumo e produção são indispensáveis, uma vez que (LIMA, 2015, p. 04):

A intensificação do consumo e da descartabilidade produz efeitos inequívocos sobre a geração de resíduos sólidos e sobre a degradação dos recursos naturais, razões que tornam sua consideração indispensável no debate ambiental e no planejamento da gestão dos resíduos sólidos.

Visando a promoção da eficiência do uso de recursos energéticos e naturais, da infraestrutura sustentável e do acesso a serviços básicos, as metas do objetivo 12 priorizam como ferramentas principais ao seu alcance: a informação, a gestão coordenada, a transparência e a responsabilização dos atores consumidores de recursos naturais. (PNUD, 2019)

Pode-se destacar algumas metas ligadas à temática de gestão de resíduos sólidos, dentre elas o uso eficiente dos recursos naturais; a redução pela metade do desperdício de alimentos per capita mundial, em nível de varejo e do consumidor, e reduzir as perdas de alimentos ao longo das cadeias de produção e abastecimento, incluindo as perdas pós-colheita; o alcance ao manejo ambientalmente adequado dos produtos químicos e de todos os resíduos, ao longo de todo o ciclo de vida destes, e a redução substancial na geração de resíduos por meio da prevenção, redução, reciclagem e reúso;

Em 2010 a Lei Federal 12.305 institui a Política Nacional de Resíduos Sólidos (PNRS), dentre os objetivos desta lei estão o estímulo à adoção de padrões sustentáveis de produção e consumo de bens e serviços, e a Gestão integrada de resíduos sólidos. Então verifica-se uma consonância nacional às tendências mundiais e aos objetivos do desenvolvimento sustentável (ODS). (BRASIL, 2010; PNUD, 2019)

Por definição dada na PNRS, a gestão integrada de resíduos sólidos é o conjunto de ações voltadas para a busca de soluções para os resíduos sólidos, de forma a considerar as dimensões: política, econômica, ambiental, cultural e social, com controle social e sob a premissa do desenvolvimento sustentável e na gestão e gerenciamento de resíduos sólidos, deve ser observada a seguinte ordem de prioridade: não geração, redução, reutilização, reciclagem, tratamento dos resíduos sólidos e disposição final ambientalmente adequada dos rejeitos. (BRASIL, 2010)

A produção e disposição inadequada de resíduos sólidos constitui um problema ambiental de grande magnitude, pois ocasiona contaminação dos solos e dos mananciais de água, problemas na drenagem pluvial e favorecimento a enchentes, poluição do ar, proliferação de vetores de doenças, dentre outros prejuízos à saúde da população direta 
ou indiretamente envolvida no manejo, além de ocupar áreas que poderiam ter outras finalidades.

Sabe-se que em áreas urbanizadas essa problemática é mais agravada que em áreas rurais, porém à medida que a população rural passa a demandar por outros bens e serviços, a geração de resíduos sofre aumento, implicando em problemas ambientais ainda mais difusos e difíceis de solucionar.

Lima (2015, p. 07) apresenta um panorama de dados e estimativas a cerca dos resíduos sólidos urbanos no Brasil e considera que:

\begin{abstract}
Esse conjunto de dados sobre geração, coleta domiciliar, destinação final, coleta seletiva, resíduos orgânicos, compostagem e reciclagem, ainda que geral, representa o lado mais visível e objetivo da gestão dos resíduos sólidos domiciliares no Brasil e são eles que centralizam a maior parte dos debates e das análises. É com base nesses grandes números que os analistas do tema têm construído os diagnósticos atuais, os prognósticos futuros e as recomendações de políticas e de gestão para o setor, estimativas que, em grande medida, coincidem com as metas da recente PNRS.
\end{abstract}

A PNRS incumbe ao Distrito Federal e aos Municípios a responsabilidade pela gestão integrada dos resíduos sólidos gerados nos respectivos territórios. A política traz também o princípio da Responsabilidade Compartilhada, que coobriga todos os geradores de resíduos sólidos a gerenciar seus resíduos de forma adequada. (BRASIL, 2010).

Lima (2015) fez uma análise cuidadosa da geração de resíduos e constatou que "o equacionamento desse conjunto de metas objetivas depende de uma complexa estrutura de gestão e de políticas que articulem múltiplos atores e fatores políticoinstitucionais, culturais, educacionais, sociais e econômicos de difícil coordenação.”

O autor cita desafios a serem enfrentados através de gestão compartilhada e a necessidade da mudança de cultura nas relações entre governo, empresas e movimentos de catadores de resíduos. Ele ainda enfatiza a importância dos catadores na prestação de serviço que realizam com escasso reconhecimento e valorização, remuneração, segurança sanitária e apoio institucional. Entretanto não se pode alimentar a crença de que a reciclagem seria solução suficiente para o problema ambiental proveniente da geração de resíduos. (LIMA, 2015)

Teoricamente todo produto pode ser reciclado, porém a viabilidade da reciclagem só acontece quando existe um mercado interessado no processamento desse material e tecnologia capaz de tornar seus custos aceitáveis. Logo, a reciclagem tem 
limites que merecem ser considerados na construção de uma estratégia complexa de gestão dos resíduos sólidos.

\section{CONSIDERAÇÕES FINAIS}

Os debates recentes sobre consumo levam à conclusão lógica de que a única maneira de evitar o colapso de recursos naturais é adotando uma postura responsável, de forma que possamos viver de acordo com a capacidade produtiva do Planeta. Essa expectativa parece uma meta inatingível, dada a centralidade que o consumo assumiu na vida econômica e sociocultural contemporânea, mas acredita-se que seremos capazes de substituir o atual modelo social por um mais sustentável.

O uso de metodologias como "Produção mais limpa" e "Melhoria contínua", assim como a aplicação de conceitos como ecologia industrial, circularidade e fortalecimento da produção local podem ser o caminho de redução do consumo de insumos produtivos e matérias-primas, ajudando a mitigar a geração de resíduos sólidos.

Torna-se essencial a adoção da economia circular, centrada na redução, reutilização, restauração e regeneração de materiais e energia em circuitos fechados, como novo valor na sociedade, gerando oportunidades e benefícios econômicos e socioambientais. (DA SILVA, 2019)

No Brasil, faz-se necessária a aplicação da gestão integrada de resíduos sólidos instituída pela PNRS e o fortalecimento das relações entre os responsáveis coobrigados na geração de resíduos, assim como a destinação de recursos para que municípios possam atender à legislação.

\section{REFERÊNCIAS}

BAUMAN, Z. Consuming Life. Journal of Consumer Culture, Oxford, v. 1, 2001.

BRASIL. Lei n. 12.305 de 02 de agosto de 2010. Institui a Politica Nacional de Resíduos Sólidos; altera a lei n.9.605, de 12 de fevereiro de 1998; e dá outras providencias. Diário Oficial da República Federativa do Brasil, Poder Executivo, Brasília DF.

DA SILVA, Valdenildo Pedro. Economia circular: Um novo valor para negócios sustentáveis. RAE-Revista de Administração de Empresas, v. 59, 2019. ISSN 2178 938X. Disponível em:

<http://bibliotecadigital.fgv.br/ojs/index.php/rae/article/view/79720/76249>. Acesso em: 01 Nov. 2020. 
CORRÊA, Leonardo Morais. A Sociedade do Desperdício Absoluto. Pensador Mercadológico, 2011. Disponível em:

<https://www.pensadormercadologico.com.br/blog_arquivos/4096>. Acesso em: 09 Nov. 2020.

LEBOW, Victor. The Real Meaning of Consumer Demand. Journal of Reatiling, 1955. Disponível em: <http://hundredgoals.files.wordpress.com/2009/05/journal-ofretailing.pdf >. Acesso em 05 Nov. 2020.

LEONARD, Anne. A História das coisas (The story of stuff). Versão online, 2007.

LIMA, Gustavo Ferreira da Costa Lima. Consumo e resíduos sólidos no Brasil: As contribuições da Educação Ambiental. RBCiamb - Revista Brasileira de Ciências Ambientais, n. 37, 2015. ISSN 2176-9478.

PNUD Brasil. Programa das Nações Unidas para o desenvolvimento:

Implementação das metas da Agenda 2030 garante o cumprimento dos ODS. 2019. Disponível em:

<https://www.br.undp.org/content/brazil/pt/home/presscenter/articles/2019/implementa cao-das-metas-da-agenda-2030-garante-o-cumprimento-dos.html>. Acesso em 05 Nov. 2020.

ROSA, H. Social Acceleration: Ethical and Political Consequences of a Desynchronized High-Speed Society. Constellations, v. 10, 2003.

SEVERIANO, M. F. V. Aceleração Social e Cultura Digital: novas formas de dominação. Revista Comunicações, Piracicaba, v. 24, 2017.

SOUZA, Jéssica Silva; MIYAZAKI, Vitor Koiti; ENOQUE, Alessandro Gomes. Reflexões acerca do consumo verde e sustentável na sociedade contemporânea. Cadernos EBAPE.BR, Rio de Janeiro, v. 17, 2019. ISSN 1679-3951. Disponível em: <http://bibliotecadigital.fgv.br/ojs/index.php/cadernosebape/article/view/67434>. Acesso em: 01 Nov. 2020.

VARGAS, C. B. Sustentabilidade e consumo consciente: a percepção da evolução do modo de consumir e como isso pode afetar a gestão nos próximos anos. In: AMOSTRA DE INICIAÇÃO CIENTIFICA, PÓS-GRADUAÇÃO, PESQUISA E EXTENSÃO, 15., 2015, Caxias do Sul. Anais. Caxias do Sul, RS: Universidade de Caxias do Sul, 2015. 


\section{$\mathbf{V}$ \\ PEGADA ECOLÓGICA, ODS 12 E GESTÃO DERESÍDUOS}

Flávia Mendes Magalhães ${ }^{20}$

Desenvolvimento sustentável consiste em descobrir como o planeta pode proporcionar recursos suficientes para assegurar o bem estar das pessoas que nele habitam, onde quer que estejam. Neste contexto, as pegadas ecológica, hídrica e de carbono demonstram que a humanidade está vivendo, atualmente, além da capacidade da Terra (Galli et al., 2012).

No início de 1990, o conceito de pegada ecológica (PE) foi introduzido por William Rees e Mathis Wackernagel, como uma medida da apropriação humana de áreas produtivas biologicamente (Rees, 1992; 1996; Wackernagel et al., 2004). A pegada ecológica se baseia na possibilidade de que a demanda da humanidade por recursos naturais seja maior do que o planeta pode ofertar de forma sustentável. O excesso de consumo é significativo por conta da rápida expansão econômica, urbanização, mudanças de estilo de vida e outras transições sociais.

Em outras palavras, demonstra se o consumo feito de determinada população em certa região é viável, ou seja, se há recursos suficientes para produzir bens e serviços que serão consumidos. Três atributos principais são levados em consideração, são eles: i) eficiência material e energética; ii) tamanho do consumo de bens e serviços por pessoa e iii) tamanho da população. A página da Global Footprint Network (GFN), organização sem fins lucrativos criada em 2003, disponibiliza esses resultados de diversos países e regiões.

Este trabalho visa correlacionar o conceito de Pegada Ecológica com os Objetivos de Desenvolvimento Sustentável e os Resíduos Sólidos, chegando à conclusão de que uma economia verde, com baixa emissão de carbono, pode ser muito benéfica e mitigar impactos da população no meio ambiente e no planeta.

\footnotetext{
${ }^{20}$ pós-graduanda em Gestão de Resíduos Sólidos Socialmente Integrados (UFBA). Integrante do grupo de pesquisa Gestão Ambiental e Desenvolvimento de Empreendimentos Sociais (GamDes/UCSAL). E-mail: flaviamendesmagalhaes@gmail.com
} 


\section{PEGADA ECOLÓGICA E DESENVOLVIMENTO SUSTENTÁVEL}

O conceito de pegada ecológica é a ideia por trás do Dia de Sobrecarga da Terra (Earth Overshoot Day) Calculado pela Global Footprint Network, mensura o dia a partir do qual a demanda por recursos e serviços dos ecossistemas alcança seu limite anual, sem que haja regeneração. Desde 1970 este dia é calculado, e em 2019, foi alcançado em 31 de julho. Isto mostra o contínuo aumento da demanda humana por bens e serviços do meio ambiente e a crescente incapacidade de recuperação natural dos ecossistemas.

Os efeitos desse modelo de desenvolvimento acarretaram no aquecimento global, aumento no buraco na camada de ozônio, poluição, contaminação do solo, poluição do ar, escassez de recursos naturais, na extinção de espécies, entre outros, ratificando a insustentabilidade deste modelo e ameaçando a vida no planeta.

Segundo a WWF (2010), a pegada ecológica da humanidade vem dobrando de tamanho desde 1966 e, em 2007, a biocapacidade utilizada do planeta foi 50\% maior que sua recuperação. $\mathrm{O}$ modo de produção e consumo da população, a partir da década de 80 tem gerado uma dívida ecológica enorme e preocupante. Continuando com esse padrão econômico, até 2030, projeções da WWF (2010), sugerem que a humanidade precisará da biocapacidade de dois planetas Terra para absorver os resíduos de $\mathrm{CO} 2 \mathrm{e}$ manter o consumo de recursos naturais.

Para efetuar a medição do uso da terra, divide-se em: cultura agrícola, pastos, florestas, áreas de pesca, área construída e áreas de sequestro de carbono, que evitam que rejeitos da combustão fóssil impactem o meio ambiente (EWING et al., 2010). Para simplificar a coleta de dados estatísticos sobre o consumo humano, o método da Pegada Ecológica adota uma classificação de cinco categorias: alimentação, habitação, transporte, bens de consumo e serviços. A pegada ecológica é medida em gha (hectares globais)

O cálculo é feito com base no consumo realizado dentro de seus limites geográficos. O processo é representado pela equação:

$$
P E_{C}=P E_{p}+P E_{i}-P E_{e}
$$

Em que $P E_{c}$ é a pegada ecológica do consumo, $P E_{p}$ é a demanda por bens da região fornecidos pelo ecossistema, como alimentos e produtos florestais, pela biocapacidade das áreas urbanas e pela biocapacidade necessária para sequestrar o carbono emitido pela população dessa região. $P E_{i}$ compartilha da 
mesma demanda, porém se relaciona à produção de bens de fora da região considerada (importações), e $P E_{e}$ é a parcela da $P E_{p}$ que corresponde à produção da região visando as exportações (EWING et al., 2010).

O conceito de pegada ecológica se relaciona diretamente com os Objetivos de Desenvolvimento Sustentáveis, criados pela Organização das Nações Unidas (ONU). Adotada em setembro de 2015 por 193 Estados Membros da ONU, a Agenda 2030 para o Desenvolvimento Sustentável, teve a sua implementação em 2016, dando continuidade à Agenda de Desenvolvimento do Milênio (2000-2015), e ampliando seu escopo para 17 objetivos e 169 metas. Essa iniciativa abrange o desenvolvimento econômico, a erradicação da pobreza, da miséria e da fome, a inclusão social, a sustentabilidade ambiental e a boa governança em todos os níveis, incluindo paz e segurança. (ONU ODS Brasil, 2020).

O objetivo 12, especificamente, Consumo e Produção Sustentável, expõe a mudança nos padrões de consumo e produção visando o desenvolvimento econômico e social sustentável. Metas como eficiência do uso de recursos energéticos e naturais, da infraestrutura sustentável, do acesso a serviços básicos são prioridades para a redução da pegada ecológica sobre o meio ambiente.

- A meta 12.5 visa, até 2030, reduzir substancialmente a geração de resíduos por meio da prevenção, redução, reciclagem e reuso;

- A meta 12.4 visa, até 2020, alcançar o manejo ambientalmente adequado dos produtos químicos e de todos os resíduos, ao longo de todo o ciclo de vida destes, de acordo com os marcos internacionalmente acordados;

- A meta 12.3 visa, até 2030, reduzir pela metade o desperdício de alimentos per capita mundial, em nível de varejo e do consumidor, e reduzir as perdas de alimentos ao longo das cadeias de produção e abastecimento, incluindo as perdas pós-colheita.

De acordo com a meta 12, um dos grandes problemas atuais são os resíduos sólidos, pois também deixam uma marca negativa no ecossistema. O descarte atual, desenfreado, em locais pouco apropriados (como lixões e aterros sanitários) desperdiça matéria-prima, polui solo, água, ar e põe em risco a saúde da população a curto e longo prazo. Diversas ações foram criadas para mitigar essa situação, mas ainda são poucas e ineficientes diante da demanda. Uma das recentes foi a criação, há 10 anos, da Lei 
12.305/2010, a Política Nacional de Resíduos Sólidos (PNRS), que trata das diretrizes da gestão integrada dos mesmos, gerenciamento, responsabilidades dos geradores e do poder público. (BRASIL, 2010). O ciclo de vida de um produto até o seu descarte tem uma pegada ecológica que também precisa ser mitigada.

No entanto, 38 anos antes da Política Nacional de Resíduos Sólidos ser criada, os problemas ambientais já estavam sendo discutidos, exemplo disso foi a Conferência de Estocolmo, em 1972. Ela identificou desafios importantes no campo da sustentabilidade, influenciando de maneira decisiva o debate sobre os problemas ambientais e as necessidades de desenvolvimento. Nesta conferência se produziu um documento que alarmava a necessidade da criação de uma gestão planetária dos problemas ambientais, que se tornou o Programa das Nações Unidas para o Meio Ambiente (PNUMA).

Buscando responder a todos esses questionamentos, houve um conjunto de iniciativas da ONU, como a Eco 92 - Cúpula da Terra, Johannesburg 2002 - Rio+10, a Conferência Nacional de Saúde Ambiental, a 10ª Conferência Internacional de Saúde Urbana, e as diversas COP - Painel de da ONU para Mudanças Climáticas. A importância da agenda da sustentabilidade para a sobrevivência do planeta foi consolidada e hoje é agenda prioritária do ponto de vista global.

\footnotetext{
As ameaças da atual crise econômica e ambiental estão plantadas no modelo de desenvolvimento ainda hoje aceito, caracterizado por uma economia de opulência e desperdício no norte, e de pobreza, desigualdades e necessidades prementes de sobrevivência em curto prazo no sul" (AGENDA 21, p.10).
}

O relatório de 2011 do PNUMA demonstra que a transição para uma economia verde de alta eficiência de recursos de baixo carbono seria possível se fossem investidos 2\% do PIB global por ano em dez setores estratégicos: resíduos e reciclagem; construção civil; energia; pesca; silvicultura; indústria; transporte; turismo; água e saneamento básico.

O documento prevê que o desenvolvimento econômico deve estar vinculado à melhoria do Índice de Desenvolvimento Humano (IDH), reduzindo ou mantendo sua pegada ecológica baixa. A economia verde valoriza e incentiva atividades com baixa emissão de carbono, racionalização dos recursos, integração social, proteção da biodiversidade e reforço dos serviços fornecidos pelos ecossistemas. 


\section{CONSIDERAÇÕES FINAIS}

As metodologias de políticas públicas para uma economia verde serão diferentes em cada país, afinal há condições socioeconômicas e institucionais específicas, seus recursos naturais e dificuldades ambientais. Teoricamente, todos os países teriam ganhos econômicos diretos com a transição para uma economia verde, maior produtividade, otimização de recursos, ampliação de empregos pela inovação e pelo surgimento de mercados verdes. Se forem alcançados esses objetivos, há projeções pela Network Global Footprint de que a pegada ecológica global poderia diminuir para menos de 1,2 gha (hectares globais) até 2050, reduzindo 33\% das emissões de dióxido de carbono, consequentemente limitando assim o aquecimento global. Os resultados da uma economia verde seriam benéficos para uma saúde e bem-estar populacional e ambiental com menor poluição.

\section{REFERÊNCIAS}

\section{AGENDA 21. Conferência das Nações Unidas sobre Meio Ambiente e}

Desenvolvimento. O caso do Brasil: perguntas e respostas. Brasília: MMA, 1998. Acesso em: 06/11/2020

BARROS, Cristiane Kleba Lisboa e Mirian Vizintim Fernandes. A pegada ecológica como instrumento de avaliação ambiental para a cidade de Londrina. Disponível em: http://confins.revues.org/index6395.html Acesso em: 08/10/2020

BRASIL. Lei 12.305 - Política Nacional de Resíduos Sólidos. Disponível em: http://www.planalto.gov.br/ccivil_03/_ato2007-2010/2010/lei/112305.htm Acesso em: $10 / 11 / 2020$

EWING, B.; REED, A.; GALLI, A.; KITZES, J.; WACKERNAGEL, M. Calculation methodology for the National Footprints Account, 2010 Edition. Oakland, CA:

Global Footprint Network, 2010. Acesso em: 08/10/2020

FOOTPRINT NETWORK. Index. Disponível

em: http://www.footprintnetwork.org/en/index.php/GFN/ Acesso em: 09/10/2020

FUNDO MUNDIAL PARA A NATUREZA (WWF-Brasil). Planeta Vivo. Relatório 2010: Biodiversidade, biocapacidade e desenvolvimento. Suíça:

WWF;2010. Acesso em: 08/10/2020

GALLI, A.; WIEDMANN, T.; ERCIN, E.; KNOBLAUCH, D.; EWING, B.; GILJUM, S. Integrating Ecological, Carbon and Water footprint into a "Footprint Family" of indicators: Definition and role in tracking human pressure on the planet. Ecological Indicators, v.16, p.100-112, 2012. Acesso em: 09/10/2020 
GONZALEZ, Marcos Henrique GODOI; Andrade, Daniel Caixeta. A sustentabilidade ecológica do consumo em Minas Gerais: uma aplicação do método da pegada ecológica. Belo Horizonte, v. 25, n. 2, p. 421-446, Aug. 2015. Disponível em: http://www.scielo.br/scielo.php?script=sci_arttext\&pid=S0103-

$63512015000200421 \& \operatorname{lng}=e n \& n r m=$ iso acesso em:

06/10/2020. https://doi.org/10.1590/0103-6351/2214

MATTOON, S.; KINGSLAND, H. S. Ausgust $\mathbf{2 0}^{\text {th }}$ is Earth overshoot day: The date this year our ecological footprint exceed our planet's budget. Global Footprint Network, 2013. Acesso em: 07/11/2020

MORAN, D. D.; WACKERNAGEL, M.; KITZES, J. A.; GOLDFINGER, S. H.; BOUTAUD, A. Measuring sustainable development - nation by nation., Ecological Economics v. 64, p. 470-4, 2008. Acesso em: 07/10/2020

OBJETIVOS DE DESENVOLVIMENTO SUSTENTÁVEL. Disponível em: https://odsbrasil.gov.br/ Acesso em: 09/11/2020

ORGANIZAÇÃO PARA A COOPERAÇÃO E DESENVOLVIMENTO ECONÓMICO (OCDE). Towards green growth: A summary for policy makers. OECD Meeting of the Council at Ministerial Level. Paris: OECD; 2011. Acesso em: $06 / 11 / 2020$

PROGRAMA DAS NAÇÕES UNIDAS PARA O MEIO AMBIENTE (PNUMA). Rumo a uma economia verde: caminhos para o desenvolvimento sustentável e a erradicação da pobreza. 2011. Disponível em: http://www.unep.org/greeneconomy Acesso em: 08/11/2020

REES, W. E. Ecological footprints and appropriated carrying capacity: What urban economics leaves out. Environment and Urbanization, v.4, p.121-130, 1992. Acesso em: 08/10/2020

STERN N. Stern Review: The Economics of Climate Change; 2006. Acesso em: $09 / 11 / 2020$

WACKERNAGEL, M.; MONFREDA, C.; ERB, K. H.; HABERL, H.; SCHULZ, N. B. Ecological footprint time series of Austria, the Philippines, and South Korea for 1961-1999: Comparing the conventional approach to an actual land area approach. Land Use Policy, v.21, p.261-269, 200. 


\title{
O PRINCÍPIO DA EQUIDADE INTERGERACIONAL NA LOGÍSTICA REVERSA DOS RESÍDUOS SÓLIDOS
}

\author{
Heather Rose Freeman ${ }^{21}$
}

O que os vivos devem aos que os seguem? É uma pergunta sem sentido para alguns e sem resposta para outros, mas tentadora em sua persistência, especialmente entre ambientalistas. Devido à crescente preocupação com a deterioração das condições ambientais, sistemas ao redor do mundo têm reconhecido cada vez mais os interesses de futuras gerações e as responsabilidades correspondentes das gerações presentes. Em reconhecimento aos vínculos intrínsecos entre mudança climática e direitos humanos, muitos argumentaram que os direitos humanos devem desempenhar um papel de liderança na orientação das respostas do Estado às mudanças climáticas. Um grupo cujos direitos humanos serão inevitavelmente afetados pela ação (ou inação) climática hoje são os membros das gerações futuras. No entanto, apesar de sua vulnerabilidade particular, as gerações futuras até agora passam despercebidas em grande parte nas análises de direitos humanos.

Em breve síntese, o presente estudo devota-se a analisar o ciclo de produção, por meio de canais de distribuição reversa de resíduos sólidos à luz do princípio da equidade intergeracional. Analisa também o papel de uma modelo de descarte sustentável de resíduos na garantia do direito ao meio ambiente ecologicamente equilibrado às futuras gerações. Destarte, realizou-se estudo através de um recorte da legislação internacional que destaca os direitos das futuras gerações aliado ao estudo da presença do princípio do desenvolvimento sustentável e os 17 Objetivos do Desenvolvimento Sustentável (ODS) da Organização das Nações Unidas (ONU).

\footnotetext{
${ }^{21}$ Advogada. Pós-graduanda em Direito Internacional pelo Centro de Direito e Negócios (CEDIN), Graduada em Direito pela Universidade Católica do Salvador (UCSAL). Integrante do grupo de pesquisa Direito Ambiental e Resíduos Sólidos em uma perspectiva local e internacional (LAEJU). Email: heatherrosefreeman@gmail.com
} 


\section{PRINCÍPIO DA EQUIDADE INTERGERACIONAL}

$\mathrm{Na}$ doutrina do direito internacional, é recorrente a discussão acerca da responsabilidade da tutela e garantia dos direitos humanos. Evidentemente, cada vertente é fortemente influenciada por doutrina de outras disciplinas filosóficas e éticas. Como uma questão que invoca a linguagem da justiça, muitos filósofos seguem o pensador do século XVIII David Hume em seu desdém pelos contratualistas sociais que defendem a garantia de circunstâncias de justiça a uma geração que ainda não existia.

Sua lógica, à primeira vista, parece inquestionável: sempre foi difícil imaginar obrigações reais devidas a pessoas ainda inexistentes, o que tornaria suas reivindicações irrelevantes tanto na lei quanto na lógica. No entanto, as preocupações entre o final do século XX e início do século XXI em torno da degradação ambiental reavivam a necessidade de um argumento convincente para proteger as gerações futuras. A partir desses novos desafios que tornam necessária uma estratégia compatível com a manutenção das futuras gerações surge a teoria da equidade intergeracional.

A equidade intergeracional tem timidamente conquistado espaço na legislação internacional. A Carta da Organização das Nações Unidas, documento fundador da ONU, pouco aborda sobre as obrigações de igualdade entre gerações. Na doutrina acerca da equidade intergeracional, uma referência é feita à primeira frase do Preâmbulo da Carta, que afirma que "nós, os povos das Nações Unidas, estamos determinados a salvar as gerações seguintes do flagelo da guerra" (1945). Esta denota uma promessa e um dever às gerações futuras, mas pouco se consegue extrair desse trecho algo que fundamente um equilíbrio entre os interesses das gerações presentes e futuras e a tutela do meio ambiente.

A declaração mais importante sobre desenvolvimento sustentável anterior aos Objetivos do Desenvolvimento Sustentável, é a Declaração sobre Meio Ambiente e Desenvolvimento, adotada ao final da Conferência das Nações Unidas sobre Meio Ambiente e Desenvolvimento, realizada no Rio de Janeiro em 1992. O primeiro princípio enfatizou a abordagem centrada no ser humano. Afirmou que "o ser humano está no centro das preocupações com o desenvolvimento sustentável” (1992). O segundo princípio reafirmou o princípio 21 da Declaração de Estocolmo de 1972 sobre o Meio Ambiente Humano sobre soberania de exploração de recursos naturais. O terceiro princípio da mesma declaração alinha o direito ao desenvolvimento com a 
equidade intergeracional, o qual afirma que "o direito ao desenvolvimento deve ser cumprido de forma a atender de forma equitativamente as necessidades de desenvolvimento e ambientais das gerações presentes e futuras."

Muito embora a legislação internacional aponte ser imprescindível que o direito ao desenvolvimento sustentável esteja vinculado à equidade intergeracional, não há uma referência explícita nos ODS, adotados pela Assembleia Geral da ONU em 2015. Existem algumas referências a "gerações futuras" nos ODS, quando por exemplo no preâmbulo sobre o planeta da Agenda 2030 está estabelecido que os Estados expressaram sua determinação "em proteger o planeta da degradação (...) para que possa atender às necessidades das gerações presentes e futuras" (2015). Ainda que o título desta seção sugira o que está em risco, a partir do texto fica evidente que a proteção do planeta contra a degradação é feita no interesse das pessoas de hoje e de amanhã. Em outros parágrafos, os ODS referem-se mais explicitamente às gerações presentes e futuras - e não à própria natureza - como beneficiários: "Implementaremos a Agenda do Desenvolvimento Sustentável para o benefício de todos, para a geração de hoje e para as gerações futuras" (parágrafo 18).

A parte mais relevante é a seção intitulada "Um apelo à ação para mudar o nosso mundo". Esta seção se refere a todas as diferentes gerações e como elas se relacionam entre si. "Setenta anos atrás", assim começa, "uma geração anterior de líderes mundiais se uniu para criar as Nações Unidas” (parágrafo 49). E agora, a geração atual, assume o controle, e "podemos ser a primeira geração a ter sucesso em acabar com a pobreza; assim como podemos ser os últimos a ter a chance de salvar o planeta" (parágrafo 50).

É possível verificar nessas observações os traços da teoria da "confiança intergeracional": a ideia de que a geração presente passa o mundo que herdou das passadas para as que virão. É muito mais difícil identificar nos ODS quaisquer vestígios da abordagem dos "direitos intergeracionais". É evidente que existem referências aos direitos humanos internacionais, mas essas se referem apenas aos direitos pertencentes aos indivíduos da geração atual.

A teoria mais influente de equidade intergeracional na doutrina de direito internacional é a desenvolvida por Brown Weiss. A autora defende que os recursos naturais são passados pela geração anterior, e que estes então deverão ser passados para as gerações futuras.

Brown Weiss, reitera o tema: 
(...) nós, a espécie humana, temos o ambiente natural e cultural de nosso planeta em comum com todos os membros de nossa espécie: as gerações passadas, a geração presente e as gerações futuras. Como membros da geração atual, temos a confiança da terra para as gerações futuras. Ao mesmo tempo, somos beneficiários do direito de usá-lo e nos beneficiar dele (tradução nossa) (WEISS, 1996,p.72) ${ }^{22}$

Trabalhos mais recentes de Edith Brown Weiss (1989) argumentam que as preocupações ambientais oferecem um papel para os direitos humanos na justiça intergeracional apresentando os direitos planetários como direitos humanos ambientais que trabalham para proteger os interesses do futuro. Esses argumentos representam tentativas iniciais de reunir os conceitos de direitos humanos e justiça, junto com o desenvolvimento sustentável.

A equidade intergeracional possui três princípios básicos que fundamentam a tutela diacrônica do direito ao meio ambiente. Primeiramente a cada geração deve ser exigida a conservação da diversidade da base de recursos naturais e culturais, de modo que não restrinja indevidamente as opções disponíveis para as gerações futuras na solução dos seus próprios problemas e permita a satisfação de seus próprios valores, devendo também ter direito à diversidade comparável ao desfrutado pelas gerações anteriores. Este princípio é denominado como “conservação de opções”. Em segundo lugar, cada geração deve ser obrigada a manter a qualidade do planeta para que seja transmitido em condições não piores do que aquelas em que foi recebido, e também deve ter direito a uma qualidade planetária comparável àquela apreciado pelas gerações anteriores. Este é o princípio da "conservação da qualidade". Terceiro, cada geração deve fornecer aos seus membros direitos equitativos de acesso ao legado das gerações passadas e deve conservar esse acesso para as gerações futuras. Este é o princípio da “conservação do acesso" (WEISS, 1989)

Assim, a tutela das gerações futuras no direito internacional deverá ser fundamentada nos direitos humanos. Isso requer uma releitura extremamente imaginativa dos direitos humanos, já que esses são normalmente vistos como direitos pertencentes a indivíduos ou grupos, e esses da geração futura ainda não existem. A sugestão é tratar dos direitos pertencentes à geração futura como um direito coletivo. Mesmo sendo desafiador essa revisão do escopo dos direitos humanos, já fala-se em direitos de coletivo no direito internacional, como por exemplo o direito à

\footnotetext{
${ }^{22}$ No original “...the human species, hold the natural environment of our planet in common with all members of aurs species:past generations, the present generation, and the future generations. As members of the present generation, we hold the Earth in trust for future generations. At the same time, we are beneficiaries entitled to use and benefit from it."
} 
autodeterminação dos povos. Brown Weiss se referiu a esses direitos como "direitos intergeracionais", direitos que as gerações detêm e que devem às gerações futuras. (WEISS, 1996).

O direito ao meio ambiente possui uma dimensão coletiva pautada no interesse universal e intergeracional, o que nos obriga a buscar a preservação do seu equilíbrio. Ademais, além desta coletividade, há também uma dimensão individual, uma vez que ele impacta diretamente na saúde e integridade das pessoas. Tudo isso torna o meio ambiente ecologicamente equilibrado um direito humano, devendo ser reconhecido como condição necessária para uma vida digna e sadia. Nas palavras de Édis Milaré:

o reconhecimento do direito ao meio ambiente sadio configura-se, na verdade, como extensão do direito à vida, quer sob o enfoque da própria existência física e saúde dos seres humanos, quer quanto ao aspecto da dignidade desta existência - a qualidade de vida - que faz com que valha a pena viver (MILARÉ, 2004, p.762)

Em uma frase, cada geração é "ao mesmo tempo um depositário do planeta com obrigações de cuidar dele e uma beneficiária com direito de usá-lo" (WEISS, 1998). Isso significa que o objetivo da humanidade dever ser a proteção e o bem-estar de cada geração. Neste sentido a manutenção dos sistemas de suporte à vida do planeta, processos ecológicos e condições ambientais são cruciais para uma vida saudável e meio ambiente equilibrado.

\section{LOGÍSTICA REVERSA DOS RESÍDUOS SÓLIDOS E A EFETIVIDADE DA JUSTIÇA GERACIONAL}

\subsection{Logística reversa dos resíduos sólidos}

Um dos grandes desafios enfrentados atualmente quando se trata de justiça geracional é a criação de políticas que forneçam às gerações atuais a possibilidade de explorar os recursos naturais de maneira sustentável para satisfazer suas necessidades, mas garantindo também esse mesmo acesso às gerações futuras. É necessário destacar que os princípios propostos da equidade intergeracional reconhecem o direito de cada geração de usar os recursos para seu próprio benefício, mas não apresenta roteiro de como a presente geração deve agir. Os princípios não ditam como cada geração deve gerenciar seus recursos, e no sentido de conservação do meio ambiente há o melhor interesse para o meio ambiente mesmo que seja o menos cômodo para o ser humano. O 
paradigma da humanidade em termos ambientais é a concepção eurocêntrica e visão antropocêntrica de solução dos problemas do mundo.

A crescente industrialização e modelo de desenvolvimento guiado por um sistema capitalista que tem como finalidade principal o crescimento econômico fez surgir novas demandas para gestão ambiental. Nesse cenário, como consequência, cresceu também a produção de resíduos sólidos urbanos. A emersão das questões derivadas da produção de lixo e a ausência de políticas públicas na geração dos resíduos sólidos na sociedade têm crescido significativamente como consequência do aumento do nível de consumo, bem como pelo crescimento populacional vivenciados na atualidade. Corroborando com essa ideia, Silva (2007) afirma que:

\begin{abstract}
Os resíduos sólidos estão sendo produzidos pelos seres humanos numa proporção muito maior do que deveriam produzir, desarmonizando o equilíbrio ecológico, indicando que consumimos mais do que necessitamos, acelerando assim o índice de poluição do planeta (SILVA, 2007, p.13).
\end{abstract}

Surge então a necessidade de um modelo de desenvolvimento que permita que a sociedade não apenas cresça como também que se desenvolva sustentavelmente. Para melhor compreensão do tema, torna-se necessário abordar conceitos sobre o que vem a ser desenvolvimento sustentável. Uma das mais elaboradas definições surgiu do relatório de Brundtland (1987) que o define como sendo o desenvolvimento que procura satisfazer as necessidades da geração atual, sem comprometer a capacidade das gerações futuras de satisfazerem as suas próprias necessidades. A partir da busca por um modelo de gestão de resíduos, emerge a logística reversa de resíduos sólidos que se apresenta como uma forma de efetivamente assegurar o direito ao meio ambiente ecologicamente equilibrado, preservando o direito a opções, qualidade e acessos das gerações que ainda estão por vir através do gerenciamento e da gestão de resíduos, garantindo uma base segura e flexível de recursos naturais-para as futuras gerações.

A logística reversa estende-se ao reúso e pós-uso de produtos e materiais. Algumas dessas atividades são, de certo modo, similares àquelas que ocorrem no caso de retorno interno de produtos com defeito de fabricação. Tradicionalmente, os fabricantes não se sentem responsáveis por seus produtos após o consumo. A maioria dos produtos usados é jogada fora, desperdiçada, ou incinerados com consideráveis danos ao meio ambiente. Atualmente, as empresas estão sendo forçadas a reavaliar a utilidade dos seus produtos através de legislações mais severas e por conta de maior consciência do consumidor. Na Europa, destaca-se a Alemanha por ser pioneira na 
legislação que versa sobre o descarte de produtos consumidos (Rogers e TibbenLembke, 1999).

A logística reversa se tornou um serviço importante na atividade de gerenciamento (gestão e gerenciamento são conceitos distintos, a logística reversa aqui mencionada é gerenciamento de resíduos) envolvendo a retomada de produtos e as operações envolvidas que são mais complexas do que a cadeia logística tradicional. O tradicional fluxo de mercadorias para frente envolve fluxo de mercadoria dos fabricantes aos consumidores finais. Entretanto, a logística reversa move as mercadorias no sentido oposto, isto é, dos clientes ao ponto de origem ou fabricação. Logística reversa, portanto, relaciona-se a todas as atividades logísticas de coletar, desmontar e processar produtos, usando parte de produtos e/ou materiais, de modo a assegurar uma recuperação sustentável do ponto de vista ambiental (Rogers e Tibben-Lembke, 1999).

O sistema ainda não recebe o seu destaque devido, embora seja realizada pelo setor não organizado de materiais recicláveis, como plásticos e papel (BEDER, 2012). O público de consumidores acaba se preocupado apenas com as consequências e impactos ambientais dos produtos no fim da vida útil. Estes normalmente encontram seu caminho de países desenvolvidos para países em desenvolvimento.

A logística reversa comumente tem sido usada pela indústria automobilística, fabricantes de veículos motorizados e de fotocopiadoras (KRIKKE, 1999). O sistema difere do mero gerenciamento de resíduos em que se concentra na adição de valor a um produto para ser recuperado, resultado numa nova cadeia de abastecimento, contrapondo a gestão de resíduos que envolve a coleta e o tratamentos destes que não possuem nova utilidade. A cadeia reversa é uma rede de atividades envolvidas na reutilização, reciclagem e destinação final de produtos e seus componentes e materiais associados.

\subsection{Implementação da equidade intergeracional através da logística reversa}

Como pano de fundo, é útil resumir os diferentes tipos de questões de equidade intergeracional que surgem em um contexto amplo que inclui, mas não se restringe às mudanças climáticas. Desenvolvimento e uso de recursos naturais e culturais faz surgir pelo menos três tipos de problemas de equidade entre gerações: esgotamento de recursos para gerações futuras, degradação na qualidade dos recursos e acesso discriminatório para uso e benefício de recursos recebidos de gerações anteriores. 
Em alguns casos, a geração atual pode exaurir certos recursos naturais, inclusive por meio da destruição de áreas de alta diversidade biológica. Novas espécies se desenvolvem enquanto que outras entram em extinção, mas a região em que as espécies estão desaparecendo aumentou. A diversidade biológica é importante para medicamentos, produtos industriais e outros para a robustez da terra como um sistema natural, e um direito das futuras gerações. Reduzir a diversidade de recursos para as gerações futuras levanta vários problemas, entre eles a redução da gama de recursos não renováveis disponíveis para resolver problemas no futuro e potencialmente o aumento dos preços reais dos recursos para as gerações futuras.

O modo atual de exploração dos recursos naturais esgota de várias maneiras e conflitam com os interesses das gerações futuras, levando a necessidade de consumir cada vez mais recursos que requerem processo de extração complexa, custosa e agressiva. Isso pode não esgotar fisicamente todos os recursos naturais, mas leva a preços reais dos recursos muito mais altos para as gerações futuras. Os recursos disponíveis podem ser mais caros para extrair ou podem não ser tão úteis. Se o preço real líquido de um determinado recurso for mais alto no futuro, haverá uma questão equitativa de quais comunidades na geração futura deverão arcar com seus custos mais elevados.

A logística reversa se mostra como ferramenta essencial na garantia da justiça geracional não somente pela sua preservação dos recursos naturais, mas também pelo âmbito da viabilidade econômica para as futuras gerações de ter acesso a esses. "Um sistema eficiente de logística reversa pode vir a transformar um processo de retorno altamente custoso e complexo em uma vantagem competitiva" (CAMPOS, 2006). Assim, é possível visualizar através da logística reversa a vantagem da produção de novos produtos com menores custos através reutilização de materiais por meio da reciclagem, recondicionamento ou outro tipo de reaproveitamento.

A reciclagem é referida como a remoção de materiais de um produto ou pacote descartado para que eles possam ser utilizados como matéria-prima para um novo produto ou embalagem. Os programas de reciclagem agora são essenciais para o gerenciamento de resíduos. Sendo nesse sentido um método de fim de tubo para gerenciamento de resíduos, em contraponto ao que importa as gerações futuras cujo maior interesse é o freio do consumo. Isso, e os benefícios econômicos da reciclagem na logística reversa, são de longo prazo, preservando os recursos naturais para as futuras gerações e garantindo o seu acesso com mesmo custo ou até menor que a geração atual. 
Uma grande preocupação é que todo o produto ou embalagem será enviada a um aterro caso não haja reciclagem. Em particular isso se dá porque o valor de uma garrafa de refrigerante vazia ou jornal usado frequentemente não é óbvio para os consumidores ou fabricantes, sendo assim, o incentivo para reciclar pode ser bastante baixo. Para que os recicláveis tenham valor como uma potencial nova matéria-prima, tanto a oferta quanto a demanda pelo material devem ser desenvolvidas. É aqui que a ideia de logística reversa é de suma importância.

A logística reversa começa onde as cadeias de suprimentos tradicionais terminam. Exemplificativamente, reciclar sucata economiza dinheiro, reduzindo o custo de produção durante a fabricação. A construção de produtos usando metais existentes trazidos para centros de reciclagem oferece muitos benefícios de economia, incluindo a eliminação da necessidade de minerar ou fabricar novas matérias-primas. Custos de fabricação mais baixos ajudam a manter os preços mais baixos, o que é um enorme benefício para empresas que compram equipamentos de escritório em grandes quantidades e reduz o custo para o consumidor. Existem benefícios de custo claros para reciclar alumínio e metais, incluindo a economia na quantidade de energia necessária para fazer um novo produto do zero. Dessa forma, geraria menos resíduo sólido e permitiria a produção de novos produtos a custos mais baixos acessíveis para as futuras gerações.

O princípio da equidade intergeracional se faz presente na logística reversa de resíduos sólidos também por ser ferramenta de destinos finais do resíduo sólido de maneira sustentável. A logística reversa é uma prática organizacional de fundamental importância para a garantia do direito ao meio ambiente das gerações futuras, contribuindo para a preservação, e redução de poluição do solo, água e ar. Não há base normativa para preferência da geração presente em detrimento das gerações futuras. Seu corolário é o conceito de parceria entre a espécie humana e o sistema natural e entre as gerações passadas, presentes e futuras de pessoas em sua relação com o sistema natural. Segundo essa teoria, cada geração desejaria herdar a Terra em uma condição pelo menos tão boa quanto a de qualquer geração anterior e ter tanto acesso quanto as gerações anteriores. Isso exige que cada geração proporcione acesso equitativo aos seus recursos naturais e culturais para as futuras gerações.

Duas relações moldam a equidade intergeracional: a relação entre as gerações e a relação da espécie humana com o sistema natural. Em primeiro lugar, o ser humano é parte do sistema natural: as suas ações o afetam e vice-versa. Como os seres mais 
sencientes do sistema natural, há a responsabilidade especial de cuidar dele. Em segundo lugar, a existência humana pertence a uma comunidade de gerações. A âncora da estrutura legal que conecta as gerações é a noção de equidade, que conecta as gerações em seu uso e cuidado do sistema natural. Portanto, o sistema de logística reversa é também uma garantia de justiça geracional. Implementar um sistema sustentável será um patrimônio para as gerações futuras, passando a elas também a responsabilidade pela conservação do planeta.

\section{CONSIDERAÇÕES FINAIS}

A responsabilidade diacrônica do meio ambiente garante às gerações futuras e futuramente às gerações presentes as opções, a qualidade e o acesso ao meio ambiente. Caracterizada pela intergeracionalidade, o direito ao meio ambiente engloba uma série de obrigações não somente ao Poder Público ou Privado, mas a todas as gerações. Por ser um direito de titularidade que ultrapassa o indivíduo, cada geração deve ser obrigada a conservar a diversidade da base de recursos naturais e culturais, para que não restrinja indevidamente as opções disponíveis a futuras gerações na solução de seus problemas e na satisfação de seus próprios valores. Garante também o direito à diversidade comparável àquele apreciado pelas gerações anteriores (WEISS, 1990). Cada geração deve manter a qualidade do planeta para que seja transmitida em nenhuma condição inferior àquela em que foi recebida, garantindo a conservação da qualidade do meio ambiente. Além disso, cada geração deve fornecer a seus membros equidade de acesso ao legado das gerações passadas e deve conservar esse acesso para as gerações futuras.

Cada geração tem direito de acesso e uso do meio ambiente e dos seus resgates naturais. Muita atenção às necessidades da geração futura pode impedir que a geração atual possa se beneficiar do legado das gerações anteriores. Por outro lado, a geração atual não pode ter licença para consumir todos os frutos do meio ambiente e recursos naturais herdados de seus ancestrais, em detrimento das gerações futuras. O objetivo de programas eficazes de logística reversa é o desenvolvimento sustentável por meio da proteção ecológica e solidariedade e fraternidade às futuras gerações. O sistema de logística reversa de resíduos sólidos além de garantir o direito ao meio ambiente ecologicamente equilibrado, garante também para as gerações futuras a herança de um sistema de gestão e gerenciamento eficiente de resíduos sólidos de maneira sustentável. 


\section{REFERÊNCIAS}

BEDER, S. Responsibility and intergenerational equity. In Enough for All Forever: A Handbook for Learning about Sustainability. Illinois, EUA: Common Ground, 2012.Disponível em: https://cue.usc.edu/publications/articles-book-chapters/. Acessado em: 30 dez 2020

BROWN WEISS, E. In Fairness to Future Generations: International Law, Common Patrimony and Intergenerational Equity; Tokyo, Japão: United Nations University, p. 353-363, 1989.

BROWN WEISS, E. Intergenerational equity and rights of future generations. In The Modern World of Human Rights: Essays in Honour of Thomas Buergenthal. California, EUA. Eds.; Inter-American Institute of Human Rights: San José, 1996. Disponível em: https://www.corteidh.or.cr/tablas/31422.pdf,. Acessado em 01. Jan.2021

CAMPOS, Tatiane. Logística reversa: aplicação ao problema das embalagens da CEAGESP. São Paulo, São Paulo. Dissertação (Mestrado) - Escola Politécnica, Universidade de São Paulo, 2006. Disponível em https://pdfs.semanticscholar.org/7ca9/3f3c6e3f712390281eb52658382690311738.pdf? $\mathrm{ga}=2.9412150 .2094599328 .1610076182-1279000571.1610076182$. Acesso em $30 \mathrm{dez}$ 2020

MILARÉ, Edis. Direito do Ambiente. Revista dos Tribunais. 2004

ONU - Conferência Rio-92 sobre o meio ambiente do planeta;1992;Disponível em: https://www.senado.gov.br/noticias/Jornal/emdiscussao/rio20/a-rio20/rio-92-agenda-21e-objetivos-do-milenio-programas-para-o-meio-ambiente-e-desenvolvimento-dospaises-com-energia-limpa.aspx. Acessado em 20 out.2020.

ONU- Assembleia Geral Agenda 2030 para o Desenvolvimento Sustentável, Disponível em https://brasil.un.org/pt-br/91863-agenda-2030-para-o-desenvolvimentosustentavel. Acessado em 20 out 2020

ONU- Comissão Mundial sobre Meio Ambiente e Desenvolvimento. Reportagem transmitida a Assembleia Geral pela Secretaria Geral. Oxford, UK. 1987.Disponível em https://www.britannica.com/topic/Brundtland-Report. Acessado em: 01 nov 2020.

ROGERS, D S. e TIBBEN-LEMBKE, R S. Going Backwards: Reverse Logistics Trends and Practices. University of Nevada, EUA.. Center for Logistics Management, Disponível em: http://equinox.unr.edu/homepage/logis/reverse.pdf, Acessado em 30 out.2020

KRIKKLE, H.-HARTEN, A.- Shuur, P. Business case Oce' reverse logistics network re-design for copiers, Vol. 34, 1999. Disponível em:

https://doi.org/10.1007/s002910050095. Acessado em: 30 nov. 2020 
SILVA, I. J. da. Análise do plano de gerenciamento de resíduos sólidos implantado no hospital Getúlio Vargas em Recife -

PE. Monografia de Especialização em educação ambiental - Faculdade Frassinetti do Recife, Recife, 2007. 


\section{VII}

\section{RESÍDUOS SÓLIDOS E MUDANÇAS CLIMÁTICAS SOB A PERSPECTIVA DOS OBJETIVOS DE DESENVOLVIMENTO SUSTENTÁVEL}

Sophia Cezimbra Oliveira ${ }^{23}$

\section{INTRODUÇÃO}

Problemas ambientais como as mudanças climáticas são fontes materiais do Direito Ambiental, e isto se dá tendo em vista que as legislações ambientais surgem para normatizar situações advindas de ações antrópicas que causam problemas e danos ao meio ambiente.

Nesta perspectiva, é possível notar a vigência do antropocentrismo protecionista, que vê a natureza como um bem coletivo que deve ser preservado para garantir a sobrevivência e o bem-estar do homem, buscando um equilíbrio entre atividades humanas e os processos ecológicos.

Entretanto, apesar da vigência do antropocentrismo protecionista, diante de diversas tragédias ambientais, a atual conjuntura mundial observa a necessidade de caminhar para o dilema ético do biocentrismo, que é uma visão do mundo e do sistema jurídico em que o homem está lado a lado com a fauna, a flora e a biodiversidade, e por isso, todos merecem igual proteção.

Com isso, a atual crise ecológica, onde danos ambientais estão em evidência, demonstra que gestões políticas que não conferem a devida atenção ao meio ambiente são ultrapassadas, de forma que devem haver gestões político-ambientais com intensivos instrumentos de controle, já que a ameaça de um futuro insustentável é presente.

O crescimento econômico, a preservação do meio ambiente e a equidade social são três fatores que precisam estar intimamente ligados para que se possa alcançar um

${ }^{23}$ Graduanda em Direito (Faculdade Baiana de Direito e Gestão). Integrante do grupo de pesquisa Direito Ambiental e Resíduos Sólidos em uma perspectiva local e internacional (LAEJU-BA). E-mail: ambiental.cezimbra@outlook.com 
meio ambiente sadio para viver. Assim, há uma relevância na existência de normas jurídicas protecionistas como instrumentos de tutela dos recursos naturais disponíveis, até porque serão estas normas que irão implementar o necessário Estado Socioambiental de Direito.

A crise ambiental existente na sociedade contemporânea clama que sejam tomadas providências urgentes para a implantação deste Estado Socioambiental de Direito, até para proporcionar a manutenção do meio ambiente sadio, oferecendo a todo ser vivo o direito fundamental de se viver num clima estável.

Assim, se faz necessário enfatizar as questões referentes ao aquecimento global e às mudanças climáticas, tendo em vista que estes problemas ambientais são tão complexos que deles derivam diversos outros. Desta forma, iniciaram-se discussões ambientalistas no âmbito internacional, que culminaram na assinatura de diversos tratados que abordam o tema.

\section{A MUDANÇA CLIMÁTICA GLOBALIZADA}

A tendência do Direito Ambiental é instituir formas de evitar a concretização de danos ecológicos decorrentes de diversos problemas ambientais, dentre eles a mudança climática. Neste contexto, a Conferência das Nações Unidas sobre Meio Ambiente, também conhecida como a Conferência de Estocolmo (Suécia), trouxe grandes avanços para a adequada proteção dos ecossistemas terrestres.

No ano de 1972, a referida conferência teve como plano de fundo a ideia de globalização e proteção ao meio ambiente. Grande parte das discussões se deram em torno da necessidade de se estabelecer políticas conjuntas entre os diversos atores da proteção ao meio ambiente, tais como as nações, blocos regionais e organizações internacionais (AMADO, 2020).

Importa salientar, inclusive, que o princípio do Direito Internacional conhecido como "cooperação entre os povos" abarca a cooperação na acepção de repassar os conhecimentos tecnológicos e de proteção do meio ambiente, alcançados pelos países mais avançados e que possuem condições econômicas favoráveis de investimento e obtenção de resultados eficazes nas pesquisas ambientais (RANGEL, 2020).

É certo que o meio ambiente não conhece fronteiras meramente políticas. Assim, num sentido mais amplo, a Terra é um grande ecossistema natural que requer uma tutela 
em nível mundial, até porque os danos ambientais que são advindos das ações humanas poluidoras detêm a potencialidade de atingir todas as extremidades do planeta (AMADO, 2020).

Neste ínterim, a partir da década de oitenta do século XX, a agenda política internacional trouxe outros acordos multilaterais muito benéficos para o meio ambiente, a exemplo da Convenção-Quadro das Nações Unidas sobre Mudança do Clima, das Conferências das Partes, do Protocolo de Kyoto, dentre outros acordos que se tornaram as principais fontes formais internacionais do Direito Ambiental (THOMÉ, 2019).

Assim, é importante ressaltar que a legislação internacional, em matéria ambiental, traz como princípio fundamental a "responsabilidade comum, mas diferenciada" que se caracteriza por determinar que todos os países tenham responsabilidade pela redução da emissão de gases causadores do efeito estufa, sendo que as nações que são desenvolvidas e mais industrializadas irão assumir uma maior parcela deste compromisso.

Numa realidade mundial em que o aquecimento global e o processo acelerado de mudanças climáticas estão em vigor, a comunidade internacional se vê exponencialmente pressionada a tomar atitudes para conter tais problemas, sobretudo num contexto de previsões de alterações climáticas mais evidentes em decorrência de ações antrópicas.

Destarte, a mudança climática também entrou em debate no cenário global com o Programa Ambiental das Nações Unidas para o Meio Ambiente (PNUMA) ${ }^{24}$, a partir da Secretaria Meteorológica Mundial, que fundou o Painel Intergovernamental sobre Mudanças Climáticas (IPCC) ${ }^{25}$. Tal programa objetivava analisar e publicar, a cada cinco anos, um relatório com os aspectos científicos da alteração climática mundial, assim como os efeitos ocasionados no meio ambiente (GULARTE; OLIVEIRA, 2020).

Havia uma importância considerável no que diz respeito à relação entre o aquecimento global e a mudança do clima com os fatores sociais, ambientais, econômicos e, sobretudo, políticos. Com isso, alguns tratados internacionais trouxeram o propósito da formação de uma espécie de banco de dados globalizado acerca da mudança no clima.

\footnotetext{
${ }^{24}$ O PNUMA é a principal autoridade ambiental mundial que determina a agenda internacional sobre meio ambiente, promovendo a implementação do desenvolvimento sustentável no Sistema das Nações Unidas.

${ }^{25}$ O IPCC foi criado para sintetizar e divulgar informações científicas sobre as mudanças climáticas no mundo.
} 
Tal intercâmbio de informações ocasionou a promoção de uma conscientização acerca dos problemas ambientais decorrentes da ação antrópica, e assim, um estímulo à ampliação da participação e do engajamento das pessoas e dos países neste processo de melhoria ambiental generalizada (GULARTE; OLIVEIRA, 2020).

Imperioso destacar que a variação da temperatura terrestre é algo que ocorre naturalmente, até porque o efeito estufa, até certo ponto, é saudável para que a Terra não tenha uma temperatura muito baixa, o que acarretaria na impossibilidade de determinadas formas de vida. Entretanto, cientistas vêm atribuindo o aumento atípico da temperatura do planeta às atividades antrópicas resultantes, sobretudo, do crescimento econômico e demográfico, que estariam causando consequências irreversíveis e catastróficas ao clima (THOMÉ, 2019).

Neste sentido, é sabido que os países com as maiores emissões de gases causadores do efeito estufa são os desenvolvidos, até mesmo pelo fato de serem os que possuem maior atividade industrial. Atividades como a queima de combustíveis fósseis, processos industriais, disposição de resíduos e o desmatamento, por exemplo, possuem altas emissões de gases poluentes, e assim, com a manutenção dos modelos de produção e consumo como acontecem na atualidade, a temperatura terrestre poderá elevar-se de forma descontrolada (THOMÉ, 2019).

Com isso, pode-se depreender que mudança climática seria "toda alteração do clima que possa ser direta ou indiretamente atribuída à atividade humana que altere a composição da atmosfera mundial e que se some àquela provocada pela variabilidade climática natural observada ao longo de períodos comparáveis" (BRASIL, 2020).

\section{O DÉCIMO TERCEIRO OBJETIVO DE DESENVOLVIMENTO SUSTENTÁVEL}

Dentro da perspectiva de proteção globalizada do meio ambiente, foram firmados 17 objetivos, contendo 169 metas, no total, que visam alcançar os compromissos estabelecidos para a Agenda 2030, reforçando a necessária mobilização em prol da proteção ambiental.

É importante enaltecer que a Agenda 2030 é um compromisso assumido por 193 países coordenados pelas Nações Unidas. Tal documento abarca temáticas voltadas, inclusive, para os direitos humanos, e foi recepcionada pelo Poder Judiciário Brasileiro, 
por intermédio do Conselho Nacional de Justiça (CNJ), através do Comitê Interinstitucional da Agenda 2030 (CNJ, 2020).

Com isso, foram instituídos os 17 Objetivos de Desenvolvimento Sustentável, em que, por meio de suas 169 metas, deve-se alcançar a efetivação dos direitos humanos e a promoção do desenvolvimento sustentável, dentro do período do ano de 2016 ao ano de 2030. Ressalta-se, inclusive, que tais objetivos dão continuidade aos 8 Objetivos de Desenvolvimento do Milênio que foram construídos no Rio+20 ${ }^{26}$ (CNJ, 2020).

Posto isto, imperioso destacar quais são os 17 Objetivos de Desenvolvimento Sustentável (ODS):

1. Erradicação da pobreza. 2. Fome zero e agricultura sustentável. 3. Saúde e bem-estar. 4. Educação de qualidade. 5. Igualdade de gênero. 6. Água potável e saneamento. 7. Energia limpa e acessível. 8. Trabalho decente e crescimento econômico. 9. Indústria, inovação e infraestrutura. 10. Redução das desigualdades. 11. Cidades e comunidades sustentáveis. 12. Consumo e produção responsáveis. 13. Ação contra a mudança global do clima. 14. Vida na água. 15. Vida terrestre. 16. Paz, justiça e instituições eficazes. 17. Parcerias e meios de implementação (UNIDAS, 2020).

São 17 objetivos extremamente importantes, em que cada um, de forma individualizada, é responsável por uma determinada demanda em prol de uma melhoria mundial. No entanto, para o conhecimento que se pretende obter com esta pesquisa, é necessário realizar uma análise pormenorizada do $\operatorname{ODS}^{27} 13$, que versa sobre as ações contra a mudança global do clima.

Adotar medidas urgentes para combater as alterações climáticas e os seus impactos é o objetivo instituído no ODS 13, que se fará plenamente efetivo através das seguintes metas:

13.1. Reforçar a resiliência e a capacidade de adaptação a riscos relacionados ao clima e às catástrofes naturais em todos os países. 13.2. Integrar medidas da mudança do clima nas políticas, estratégias e planejamentos nacionais. 13.3. Melhorar a educação, aumentar a conscientização e a capacidade humana e institucional sobre mitigação, adaptação, redução de impacto e alerta precoce da mudança do clima. 13.a. Implementar o compromisso assumido pelos países desenvolvidos partes da Convenção Quadro das Nações Unidas sobre Mudança do Clima [UNFCCC] para a meta de mobilizar conjuntamente US\$ 100 bilhões por ano a partir de 2020, de todas

\footnotetext{
26 “A Conferência das Nações Unidas sobre Desenvolvimento Sustentável, a Rio+20, foi realizada de 13 a 22 de junho de 2012, na cidade do Rio de Janeiro. A Rio+20 foi assim conhecida porque marcou os vinte anos de realização da Conferência das Nações Unidas sobre Meio Ambiente e Desenvolvimento (Rio-92) e contribuiu para definir a agenda do desenvolvimento sustentável para as próximas décadas" (BRASIL, 2020).

${ }^{27}$ ODS: Objetivo de Desenvolvimento Sustentável.
} 
as fontes, para atender às necessidades dos países em desenvolvimento, no contexto das ações de mitigação significativas e transparência na implementação; e operacionalizar plenamente o Fundo Verde para o Clima por meio de sua capitalização o mais cedo possível. 13.b. Promover mecanismos para a criação de capacidades para o planejamento relacionado à mudança do clima e à gestão eficaz, nos países menos desenvolvidos, inclusive com foco em mulheres, jovens, comunidades locais e marginalizadas (UNIDAS, 2020).

Tais metas foram implementadas nas políticas públicas brasileiras, sobretudo com a Política Nacional sobre Mudança do Clima, por intermédio de políticas, estratégias e planejamentos nacionais. Entretanto, cabe destacar que a meta 13.a não é aplicável ao Brasil, tendo em vista que ele ainda não é um país desenvolvido (IPEA, 2020).

Os impactos que são causados pelo processo acelerado de mudanças climáticas afetam a integralidade do ecossistema terrestre, e é um evento transnacional que não respeita limites meramente geopolíticos. Sobre isto, é perceptível, inclusive, que quem mais sofre com tais problemas são as pessoas em estado de maior vulnerabilidade, principalmente as que são oriundas de países que ainda não são considerados desenvolvidos.

Assim, com a projeção de um aumento da temperatura terrestre superior a $3^{\circ} \mathrm{C}$ até o final do século XXI, o ODS 13 traz o intuito de mobilizar ajuda financeira, em periodicidade anual, para os países em desenvolvimento, sobretudo no que diz respeito ao plano de mitigação de desastres relacionados ao clima (PNUD; IPEA, 2020).

Desta forma, é possível notar que, ao se estabelecer um objetivo de desenvolvimento sustentável exclusivamente para tratar das questões climáticas, se torna plenamente viável e de extrema importância a manutenção de ações estratégicas, por parte dos governantes e da sociedade, para impedir um aumento sobremaneira acelerado da temperatura terrestre.

É essencial ver os 17 objetivos e suas 169 metas com um olhar coletivo totalmente desprovido de individualismos, tendo em vista que não se trata apenas de almejar uma sociedade justa na forma econômica, social e ambiental, mas também ter a plena consciência do impacto e da responsabilidade individual de cada sujeito no planeta (BARBOSA; VIEIRA, 2020). 


\section{A DESTINAÇÃO AMBIENTALMENTE ADEQUADA DOS RESÍDUOS SÓLIDOS}

Ao pensar e refletir sobre os impactos devastadores provenientes do aquecimento global, é importante se questionar sobre quais condutas estão colaborando para a aceleração deste processo. Assim, não há como não se indagar sobre a forma como a sociedade está gerindo os resíduos que produz, tendo em vista que a decomposição de resíduos e rejeitos libera demasiada quantidade de gases causadores do efeito estufa.

A existência de uma política pública destinada especificamente à regulagem do gerenciamento de resíduos sólidos é essencial para qualquer sociedade que se pretenda sustentável. Entretanto, antes de 2010 existia uma lacuna legislativa sobre este tema no Brasil, o que dava margem à distorções, por parte do Poder Público e das pessoas, na solução de problemas advindos da gestão de resíduos (SIQUEIRA, 2020).

Com isso, o Brasil publicou em 02 de agosto de 2010 a Lei ${ }^{\circ}$ 12.305/2010, que é a Lei da Política Nacional de Resíduos Sólidos (PNRS). Tal diploma normativo veio para preencher lacunas jurídicas e atender às demandas sociais acerca da correta disposição dos resíduos e rejeitos, dispondo de princípios, objetivos e instrumentos específicos para isto.

A referida lei foi publicada e regulamentada por meio do Decreto ${ }^{\circ} 7.404 / 2010$, instituindo princípios, objetivos e instrumentos importantes para a gestão integrada e o gerenciamento dos resíduos sólidos. Ela dispôs de forma ampla acerca daqueles sujeitos que estão vinculados ao seu regime, que seriam as pessoas físicas ou jurídicas, de direito público ou privado, que fossem responsáveis, direta ou indiretamente, pela geração de tais resíduos, bem como aquelas que desenvolvam ações relacionadas à gestão integrada e ao seu gerenciamento (SIQUEIRA, 2020).

Neste sentido, imperioso destacar o que dispõe Édis Milaré (2011): A Política Nacional de Resíduos Sólidos preencheu uma importante lacuna
no arcabouço regulatório nacional. Essa iniciativa é o reconhecimento, ainda
que tardio, de uma abrangente problemática ambiental que assola o País,
problemática esta de proporções desconhecidas, mas já com diversos
episódios registrados em vários pontos do território nacional, e que tem
origem exatamente na destinação e disposição inadequadas de resíduos e
consequente contaminação no solo, além da dificuldade de identificação dos
agentes responsáveis. Esses registros indicam a gravidade de situações de
contaminação do solo e das águas subterrâneas, com risco efetivo à saúde
pública e à biota, além do comprometimento do uso de recursos naturais em
benefício da sociedade. 
Esta lei é um marco fundamental na transição do predomínio clássico do sistema de comando e controles estatais de cunho corretivo-repressivo. Ela reúne diretrizes, mecanismos e instrumentos econômicos, de planejamento e gestão, propícios a incentivar a institucionalização, valorização e promoção da auto-organização de vários setores, com vistas à gestão integrada e ao gerenciamento ambientalmente adequado dos resíduos sólidos (YOSHIDA, 2012).

Entretanto, vale ressaltar que a existência de uma nova política pública, estritamente, não resolve, por si só, o problema gerado pela má gestão dos resíduos. É necessário que haja uma modificação de paradigmas conjuntamente com a quebra de padrões comportamentais das pessoas, pois normas isoladas pouco significam se forem implementadas sem a efetiva participação da sociedade.

Nesta perspectiva, percebe-se ainda outro aspecto muito importante da referida lei, tendo em vista que ela não dispõe sobre os resíduos sólidos apenas no momento do seu descarte, mas sim sobre toda a cadeia de manejo deles. A Política Nacional de Resíduos Sólidos parte de pressupostos advindos do princípio da prevenção, tendo em vista que ela objetiva, inclusive, o reaproveitamento dos resíduos muito antes de pensar em descartá-los.

Pensar em resíduos sólidos apenas no momento do seu descarte é verificar soluções com viabilidade por tempo muito limitado, até porque o volume de resíduos produzidos na atualidade ultrapassa todas as dimensões previamente imagináveis pela sociedade. Assim, a ordem jurídica não pode preocupar-se com o destino das coisas só depois de se tornarem "lixo",28, até porque a economia da gestão dos ciclos é o objetivo da revisão fundamental deste estado de coisas (KUNIG, 1994).

Com isso, é importante enfatizar os princípios da Lei $\mathrm{n}^{\circ}$ 12.305/2010, em que, através do exercício de interpretação destes, se torna possível perceber uma permanente integração com todo o corpo do mencionado diploma normativo.

Os princípios da prevenção e da precaução, por exemplo, são importantes na medida em que evitam o dano de forma mais ampla e desenvolvem os planos de gerenciamento de resíduos. Assim, somente quando não for possível evitar totalmente

\footnotetext{
${ }^{28}$ A Política Nacional de Resíduos Sólidos não dispõe nada sobre "lixo", tendo em vista que, dentro da perspectiva deste diploma normativo, "lixo" é um termo atécnico, todavia, popularmente difundido entre a sociedade para se referir aos resíduos e rejeitos.
} 
um prejuízo ambiental, será aceito um comportamento redutor ou mitigador do referido dano (NETO; ROCHA, 2020).

Da mesma forma, os planos de resíduos sólidos podem apresentar diagnósticos acerca da atual situação dos resíduos, bem como as metas de redução, reutilização e reciclagem, objetivando, inclusive, diminuir sobremaneira a quantidade de rejeitos descartados, de forma que eles sejam encaminhados para a disposição final ambientalmente adequada.

Tais planos podem ainda conter metas para eliminação de lixões a céu aberto, de aterros sanitários e de mecanismos de incineração de resíduos, levando em consideração, inclusive, a inclusão social e a emancipação econômica dos catadores de materiais recicláveis e reutilizáveis - algo que é inovador, tão importante e bem definido na lei supramencionada (NETO; ROCHA, 2020).

Ademais, outro princípio que merece destaque apropriado é o da responsabilidade compartilhada pelo ciclo de vida do produto $^{29}$, que se caracteriza por ser o conjunto de atribuições individualizadas e encadeadas dos fabricantes, importadores, distribuidores e comerciantes, além dos consumidores e dos titulares dos serviços públicos de limpeza urbana e de manejo de resíduos sólidos, para reduzir os impactos causados à saúde humana e à qualidade ambiental decorrentes do ciclo de vida dos produtos (BRASIL, 2020).

Tal princípio é essencial para a efetivação da Política Nacional de Resíduos Sólidos, com especial atenção para os distintos destinatários desta norma. Objetiva-se compatibilizar interesses entre agentes econômicos e sociais, desenvolvendo estratégias sustentáveis; promover o aproveitamento de resíduos, direcionando-os para a sua cadeia produtiva ou para outras; reduzir a geração, o desperdício, a poluição e os danos ambientais; e incentivar a utilização de insumos de menor agressividade ao meio ambiente e de maior sustentabilidade (SIQUEIRA, 2020).

A responsabilidade compartilhada impõe ainda que os sujeitos a ela submetidos divulguem informações relativas à atos de eliminação da produção de resíduos e reciclagem, devendo recolher os produtos e resíduos sólidos remanescentes após o uso da coisa, promovendo a sua destinação final ambientalmente adequada. Destaca-se

\footnotetext{
${ }^{29}$ Ciclo de vida do produto é uma série de etapas que envolvem o desenvolvimento de um determinado produto, a obtenção de matérias-primas e insumos, o processo produtivo, o consumo e a sua disposição final.
} 
igualmente a preocupação com as embalagens, que é algo tão danoso ao meio ambiente quando descartado de maneira inapropriada.

Neste sentido, a Política Nacional de Resíduos Sólidos, além de consagrar a responsabilidade compartilhada pelo ciclo de vida do produto, impôs novas perspectivas ao sistema de coleta seletiva e à ideia de gestão de resíduos sólidos, até porque o gerenciamento de resíduos sólidos passou a alocar a destinação final como última prioridade da hierarquia das ações no ciclo dos resíduos, vide art. $9^{\circ}$ da lei supramencionada (COSTA, 2020).

Frisa-se ainda que a violação dessas obrigações gerais acarreta na incidência de encargos financeiros aos poluidores. Deve-se analisar, inclusive, de forma crítica esta hierarquia, sobretudo quando ela orienta que a não geração, a redução e a reutilização venham antes mesmo da reciclagem - algo que, equivocadamente, a sociedade extremamente consumista pensa ser a solução prioritária (NETO; ROCHA, 2020).

\section{CONSIDERAÇÕES FINAIS}

É possível perceber que a decomposição de resíduos sólidos e rejeitos em aterros sanitários e lixões a céu aberto libera demasiada quantidade de gases causadores do efeito estufa. A liberação destes gases contribui diretamente para o aquecimento da temperatura terrestre e, consequentemente, para o processo acelerado de mudanças climáticas.

A efetiva implementação, pelos mais diversos sujeitos, dos mecanismos dispostos nos tratados internacionais em matéria ambiental, na legislação nacional que versa sobre clima e na Política Nacional de Resíduos Sólidos, demonstra-se verdadeiramente essencial para o combate ao processo acelerado de mudanças climáticas que a sociedade enfrenta na atualidade.

Assim, depreende-se que a partir do momento em que o $13^{\circ}$ Objetivo de Desenvolvimento Sustentável traz em seu conteúdo o combate às alterações climáticas, suas metas demonstram uma viabilidade em conduzir os gestores públicos, os órgãos fiscalizadores, os geradores de resíduos e principalmente a sociedade a trabalharem de forma conjunta para gerir e destinar os resíduos sólidos e os rejeitos de forma ambientalmente adequada. 


\section{REFERÊNCIAS}

AMADO, Frederico. Direito Ambiental. 11.ed. Salvador: Juspodivm, 2020.

BARBOSA, Danniel; VIEIRA, Mariana. Objetivos de Desenvolvimento Sustentável: o que são? Disponível em: https://www.politize.com.br/objetivos-de-desenvolvimentosustentavel/. Acesso em: 11 nov. 2020.

BRASIL. Política Nacional de Resíduos Sólidos. Disponível em:

http://www.planalto.gov.br/ccivil_03/_ato2007-2010/2010/lei/112305.htm. Acesso em: 23 mar. 2020.

BRASIL. Política Nacional sobre Mudança do Clima. Disponível em: http://www.planalto.gov.br/ccivil_03/_ato2007-2010/2009/lei/112187.htm. Acesso em: 22 mar. 2020.

BRASIL. Sobre a Rio+20. Disponível em: http://www.rio20.gov.br/sobre_a_rio_mais_20.html. Acesso em: 10 nov. 2020.

CARDOSO, Henrique Ribeiro; FEITOSA NETO, Pedro Meneses. Direito Regulatório Comportamental: vida selvagem e sustentabilidade no contex to da Agenda 2030. Revista Brasileira de Direito Animal, Salvador, v.14, 2019, n. 3. Disponível em: https://portalseer.ufba.br/index.php/RBDA/article/view/3443. Acesso em: 26 jun. 2020.

CNJ. O que é a Agenda 2030? Disponível em: https://www.cnj.jus.br/programas-eacoes/agenda-2030/o-que-e-a-agenda-2030/. Acesso em: 11 nov. 2020.

COSTA, Silvano Silvério da. Ministério do Meio Ambiente: Política Nacional de Resíduos Sólidos. Disponível em: http://a3p.mma.gov.br/wpcontent/uploads/F\%C3\%B3rum/5\%C2\%BAF\%C3\%B3rum2010/Apresenta\%C3\%A7\% C3\%B5es/1_poltica_nacional_de_resduos_slidos silvano_silvrio_36.pdf. Acesso em: 23 mar. 2020.

GULARTE, Thaís da Silva; OLIVEIRA, Rafael Santos. A Convenção-Quadro sobre Mudanças Climáticas e as responsabilizações dos Estados pela redução da emissão dos gases de efeito estufa. Revista Eletrônica do Curso de Direito da Universidade Federal de Santa Maria, Santa Maria, v. 2, 2007, n. 3. Disponível em: https://periodicos.ufsm.br/revistadireito/article/view/6823. Acesso em: 25 jun. 2020.

IPEA. 13. Ação Contra a Mudança Global do Clima. Disponível em: https://www.ipea.gov.br/ods/ods13.html. Acesso em: 11 nov. 2020

KUNIG, Philip. Do Direito do Lixo para o Direito da Correcta Gestão dos Ciclos dos Materiais? Comentários acerca da legislação alemã sobre os resíduos e a sua evolução. Revista Jurídica do Urbanismo e do Ambiente. Coimbra: Livraria Almedina, v.1, jun, 1994.

MILARÉ, Édis. Direito do Ambiente: A Gestão Ambiental em Foco: doutrina, jurisprudência e glossário. 7.ed. São Paulo: Revista dos Tribunais, 2011. 
NETO, Elias; ROCHA, Márcia Santos da. Política Nacional de Resíduos Sólidos: Princípios, Objetivos e a Educação Ambiental como um dos Instrumentos. Disponível em: http://revista.oswaldocruz.br/Content/pdf/Edicao_06_Elias_neto.pdf. Acesso em: 10 mar. 2020.

PNUD; IPEA. Plataforma Agenda 2030: Os 17 Objetivos de Desenvolvimento Sustentável. Disponível em: http://www.agenda2030.org.br/ods/13/. Acesso em: 11 nov. 2020.

RANGEL, Tauã Lima Verdan. O princípio da cooperação entre os povos como sustentáculo de preservação do meio ambiente: a inspiração dos valores transindividuais dos direitos de terceira dimensão. Disponível em: https://www.boletimjuridico.com.br/artigos/direitos-humanos/3049/o-principiocooperacao-entre-os-povos-como-sustentaculo-preservacao-meio-ambiente-inspiracaovalores-transindividuais-direitos-terceira-dimensao. Acesso em: 23 jun. 2020.

RESENDE, Augusto C. L. A tutela jurisdicional do direito humano ao meio ambiente sadio perante a corte interamericana de direitos humanos. Belo Horizonte: Fórum, 2015.

SIQUEIRA, Lyssandro Norton. Dos Princípios e Instrumentos da Política Nacional de Resíduos Sólidos. Disponível em:

http://www.mpdft.mp.br/saude/images/Meio_ambiente/Principios_intrumentos_politica _nacional.pdf. Acesso em: 02 mar. 2020.

THOMÉ, Romeu. Manual de Direito Ambiental. 9.ed. Salvador: Juspodivm, 2019.

UNIDAS, Nações. Ação contra a mudança global do clima. Disponível em:

https://brasil.un.org/pt-br/sdgs/13. Acesso em: 11 nov. 2020.

UNIDAS, Nações. Sobre o nosso trabalho para alcançar os Objetivos de Desenvolvimento Sustentável no Brasil. Disponível em: https://brasil.un.org/ptbr/sdgs. Acesso em: 11 nov. 2020.

YOSHIDA, Consuelo. Competência e as Diretrizes da Política Nacional de Resíduos Sólidos: conflitos e critérios de harmonização entre as demais legislações e normas. In: JARDIM, Arnaldo et al (Org). Política Nacional, Gestão e Gerenciamento de Resíduos Sólidos. São Paulo: Manole, 2012. 


\section{VIII \\ A FANTÁSTICA FÁBRICA DE BRINQUEDOS: \\ $O$ (DES)CUMPRIMENTO DAS METAS PARA O \\ DESENVOLVIMENTO SUSTENTÁVEL DA AGENDA 2030}

Cláudia Azevedo de Jesus ${ }^{30}$

Neste trabalho, pretende-se analisar os padrões de produção e consumo dos brinquedos plásticos no Brasil e sua (in)eficiência para cumprir as metas para o desenvolvimento sustentável da Agenda 2030.

Para tanto, primeiramente, far-se-á análise da história do plástico e da cadeia dos brinquedos plásticos: a origem da sua matéria-prima, o processo de produção e desafios de descarte e reciclabilidade. Em um segundo momento, abordar-se-á a relação do consumo com a regulamentação da publicidade infantil. Desde pequenas as crianças são estimuladas a desejar produtos, muitas vezes, supérfluos e desnecessários, que provoca o consumo exagerado, tornando-as poluidoras em potencial. E por fim, apontará as metas relativas ao consumo e produção para o desenvolvimento sustentável da Agenda 2030, sob a perspectiva planetária, incorporada a noção de limites na oferta de recursos naturais, com o olhar para o ciclo de vida do produto, no intuito de fomentar a ideia de economia circular para as fábricas de brinquedos e para as novas gerações.

O método utilizado para elaboração do presente artigo utilizar-se-á a pesquisa exploratória, a revisão bibliográfica, e análise documental, para que através do método hipotético-dedutivo consiga alcançar a relação entre produção, consumo infantil e o direito ao meio ambiente ecologicamente equilibrado para a presente e futuras gerações.

\section{A HISTÓRIA dO PLÁSTICO}

Os primeiros polímeros sintéticos foram criados no século 20, mas a produção a nível industrial começou apenas na década de 1950. O plástico se destaca pela sua capacidade de ser moldado por calor ou pressão, e transformado em inúmeros modelos

\footnotetext{
30 Bacharel em Direito pela Universidade Católica do Salvador (UCSal). Email: claudia.jazevedo@gmail.com
} 
e outros objetos. As maiores produções do mercado incluem tereftalato de polietileno (PET), polietileno de alta, e baixa densidade linear (HDPE, LDPE e LLDPE), cloreto de polivinila (PVC), polipropileno (PP) e poliestireno (PS) (CHAMAS et al.,2020).

Antes da era do plástico, materiais como argila, vidro e marfim eram utilizados para molde e transformação em outros produtos. Com a descoberta da indústria petroquímica, os produtos derivados de petróleo fóssil, tornou-se altamente produzido devido a sua propriedade de ser moldado em qualquer formato, por meios de processos físicos conhecidos como rotação, injeção, extrusão, compressão, dentre outros (CHAMAS et al., 2020).

Ao longo da história, em 1839, o americano Charles Goodyear criou o processo de vulcanização da borracha, tornando o material mais resistente às variações de temperatura, e permitindo maior elasticidade. Em 1870, o americano John Wesley Hyatt, aperfeiçoou o celuloide, permitindo maior rigidez ao plástico. Em 1909, foi criado a baquelite, uma resina sintética, que revolucionou a escala comercial do plástico e trouxe rigidez e durabilidade após ser moldada. Nas décadas de 1930 a 1950, iniciou a era da polimerização, diversificando os polímeros, para a produção de poliéster, EPS (Isopor®), PVC (vinil), poliuretano, náilon, PET, teflon, silicone, polipropileno e polietileno (PINTO, 2012)

A produção dos termoplásticos, trouxe consequências incalculáveis no estilo de consumo da sociedade moderna. Atrelado ao custo benefício, a durabilidade, a estética e sua capacidade de transformar-se sem perder suas propriedades mecânicas e físicas, a produção em grande escala superou a maiorias dos outros materiais, determinado o que pode ser chamado de "revolução dos materiais" (PIATTI, 2005). Com tanta versatilidade e conveniência, o uso do plástico trouxe consequências substanciais para o meio ambiente e a saúde, o resíduo proveniente do plástico são encontrados em todo o mundo. A porcentagem da fração de plástico na composição dos resíduos em uma escala de 1 a 24,7 por cento, corresponde a 13,5\% no Brasil, 14,6 na Argentina, 10 na China, 13 no Egito, 12.4 nos EUA, 12,1\% na Mongólia, 14.6 na Itália, e 18\% na Latvia (Norte Europeu). (WASTE ATLAS, 2020)

Em razão de seu uso tão difundido mundialmente, grande parte dos resíduos gerados é proveniente deste material, e a participação de plástico nos resíduos sólidos urbanos (em massa), aumentou de 1\% em 1960 para mais de 10\% em países de renda média e alta (GEYER, R. et al. 2017). A média de resíduos sólidos gerados anualmente por pessoa (kg/ano), está concentrada em países desenvolvidos como Canadá (777), 
Dinamarca (747), Alemanha (617), Austrália (640), Irlanda (586), com destaque também para o Kuwait (709), Guiana (558) e Brasil (383). (WASTE ATLAS, 2020)

Apesar da escassez de evidências científicas no tempo de degradação de cada tipo de plástico e suas condições expostas ao meio ambiente, existe na literatura, tempos estimados conhecidos de degradação para plástico de 70 a 450 anos. E é justamente essa propriedade de durabilidade do plástico, que fez deste material tão versátil e requisitado uma ameaça ao meio ambiente. Nenhum dos plásticos comumente usados são biodegradáveis, sendo assim, ao invés de se decompor ele se acumula no solo, no ar e nos oceanos mais profundos do mundo (CHAMAS et al., 2020).

Nos moldes da Lei de Política Nacional do Meio Ambiente (PNMA) - Lei $\mathrm{n}^{\circ}$ 6.938/81, os resíduos plásticos possuem a natureza jurídica de poluente, pois como alude o art. $3^{\circ}$, inciso III, haverá poluição quando:

a) prejudiquem a saúde, a segurança e o bem-estar da população; b) criem condições adversas às atividades sociais e econômicas; c) afetem desfavoravelmente a biota; d) afetem as condições estéticas ou sanitárias do meio ambiente; e) lancem matérias ou energia em desacordo com os padrões ambientais estabelecidos.

Embora o plástico tenha sido muito importante para o processo de desenvolvimento econômico, seu uso excessivo, e toda sua versatilidade comprometeu o meio ambiente, pois mais da metade de todo o plástico produzido é projetado para ser usado apenas uma vez, em uma vida útil de 100 a 500 anos. Segundo dados da ONU, a produção é de 300 milhões de toneladas de resíduos plásticos todos os anos, o equivalente ao peso de toda população humana (ONU, 2018)

Nos dados do relatório da ABRELPE (2018), o Brasil gerou 79 milhões de toneladas de resíduos sólidos, a destinação ambientalmente adequada em aterros sanitários recebeu apenas 59,5\% dos resíduos coletados, o restante, 29,5 milhões de toneladas foram despejados em locais inadequados.

Diante deste contexto, qual a relação entre a história do plástico e a fábrica de brinquedos? A cerca de 50 anos atrás, os brinquedos eram produzidos em metal ou madeira, e as brincadeiras eram sempre projetados para algum contato com a natureza. Com o advento dos hidrocarbonetos fósseis, e o custo benefício do plástico, a indústria de brinquedos gradualmente foi se apropriando desses novos materiais, e passaram a ser matéria-prima base para produção de brinquedos infantis.

No final dos anos 1940, a Fischer Price foi a primeira empresa a fazer toda sua linha de produção em plástico. A venda dos brinquedos produzidos a partir dos 
termofixos foi um sucesso e impulsionou a produção em grande escala dos brinquedos plásticos (PLASTICS-THEMAG, 2011).

Segundo o último relatório da ABRINQ (2020), o faturamento da indústria brasileira de brinquedos 2019 foi de R \$ 7,3 milhões, e com prevalência dos países asiáticos na importação dos brinquedos, destaque para China, Vietnã, Indonésia, Malásia e Hong Kong, o que corresponde a quase 50\% do faturamento da produção nacional.

Uma característica da produção de brinquedos mundial é sua concentração na China, o que equivale a $70 \%$ da produção mundial de brinquedos, enquanto as duas maiores empresas de brinquedos norte-americanas (Mattel e Hasbro) lideram a comercialização das principais marcas mundiais. A china também representa $37 \%$ de toda importação de plástico no Brasil (ABDI, 2011).

No relatório da WWF (2019), apresenta a poluição plástica uma ameaça à natureza e à sociedade, até 2016, a produção de plástico já alcançou a marca de 396 milhões de toneladas métricas já produzida, o que resultou em aproximadamente 2 bilhões de toneladas métricas de emissões de dióxido de carbono.

Uma pesquisa feita pela Universidade Federal de São Carlos (UFSCar, 2020), apoiada pelo Instituto Alana, estima que $90 \%$ dos brinquedos produzidos são derivados de plástico. Ademais, a fabricação de brinquedos responde por cerca de $4 \%$ do consumo de petróleo, originário das indústrias de transformação, sendo o PVC o mais utilizado na sua composição (ABDI, 2011).

Há dois grandes problemas quando se fala em produção dos brinquedos plásticos no Brasil: a rotulagem do material e a complexidade da reciclabilidade. $\mathrm{O}$ selo de identificação de conformidade, disponibilizado pelo Instituto Nacional de Metrologia, Qualidade e Tecnologia após os brinquedos serem testados por laboratórios credenciados, não informa com clareza as substâncias compostas nos brinquedos, tornando mais difícil a comparação dos produtos para um consumo mais sustentável (INMETRO, 2005). E essa situação pode ser agravada, se a compra do produto for efetuada pela internet; na ficha técnica do produto, onde deveria vir explícito o tipo de material utilizado na sua composição, se resume a simples informação de que contém plástico.

Em 2015, o Brasil instituiu a Política de Educação para o Consumo Sustentável, com o objetivo de estimular a adoção de práticas de consumo e de técnicas de produção ecologicamente sustentáveis, consta no art. $2^{\circ}$, inciso VIII, da referida lei, o objetivo de 
“zelar pelo direito à informação e pelo fomento à rotulagem ambiental”. Sendo assim, para que os pais exerçam compra consciente e responsável, visando a preservação do meio ambiente, os dados de cunho ambiental devem ser compreendidos no conceito de características e qualidades do produto, capaz de educar a decisão de compra.

Além disso, a reciclabilidade do plástico precisa ser feita com base no tipo de polímero, já que alguns plásticos se contaminam quando misturados, e afetam o grau de pureza do produto, uma vez que os brinquedos direcionados às crianças geralmente recebem pigmentação, textura, glitter, materiais eletrônicos e outros componentes para ficarem mais atrativos, tornando praticamente inviável sua reciclagem (GPQV/UFSCar, 2020). Da mesma maneira, os brinquedos plásticos, em sua grande maioria, não vêm impresso o tipo de polímero usado na sua composição, dificultando o processo de separação do material pelos pais e pelas cooperativas de reciclagem.

Além dos problemas decorrentes da poluição plástica no solo e na vida marinha, um estudo inédito promovido pelo Ministério do Meio Ambiente da Alemanha, divulgado pela revista Der Spiegel detectou níveis alarmantes de subprodutos plásticos em $97 \%$ das amostras de sangue e urina de 2.500 crianças testadas. De acordo com a pesquisa, as crianças mais novas são as mais atingidas, e crianças oriundas de família mais pobres possuem maior índice de contaminação comparada com as crianças de classe média alta (RHAN, 2019).

Outro estudo promovido pelo Centro de Química e Meio Ambiente, Instituto de Pesquisas Energéticas Nucleares de São Paulo (2009), encontrou em brinquedos de plásticos, proveniente dos países asiáticos, metais como cádmio, chumbo, cromo, mercúrio, alumínio, cobre e tório, acima do limite permitido pelo INMETRO (ZINI, J. et al. 2009).

Baseados nos dados extraídos em plataformas oficiais de produção industrial é possível prever que em 2030, o Brasil pode chegar a produção anual de quase 158 mil toneladas de brinquedos. Contudo, os dados de impacto dos brinquedos no meio ambiente não abrangem as embalagens, que são feitas, frequentemente, para o descarte imediato. Estima-se que $45 \%$ do peso total do produto corresponde às suas embalagens, e ainda que elas sejam produzidas em papelão, em sua grande maioria passam por tratamento com verniz e pigmentação, o que pode inviabilizar a reciclagem (GPQV/UFSCar, 2020). 


\section{CRIANÇA E CONSUMO}

Apesar da indústria de brinquedos formal não ter representatividade em números, na cadeia de transformados plásticos ela possui um papel relevante na educação e no desenvolvimento das crianças. O brinquedo ao longo dos anos assumiu papel significativo no desenvolvimento e aprendizagem infantil, onde a função do brinquedo é a brincadeira, que tem como princípio estimular o indivíduo biopsicossocial (CARDOZZO; VIEIRA, 2007).

É na atividade lúdica que a criança descobre a relação existente entre os seres, além de se apropriar de códigos culturais e de papéis sociais. O brincar, através dos brinquedos, auxilia a criança a desenvolver os aspectos de percepção, habilidades motoras, estímulos visuais e sensoriais. Além disso, o brinquedo incorpora o imaginário criado pelo universo infantil, a partir dos desenhos animados, do super-herói, das fadas, dentre outros (CARDOZZO, S.T.D;VIEIRA, L.M. 2007).

Contudo, mesmo diante da procura que incide sobre os brinquedos, em um sistema ordenado por uma economia linear (comprar-usar-jogar fora), é necessário formar cidadãos capazes de desenvolver uma mentalidade baseada no modelo circular, para que no futuro, os indivíduos formados favoreçam a criação de produtos mais duráveis e com o mínimo de impacto negativo no meio ambiente.

O consumismo como atributo da sociedade moderna, nos dizeres de Zygmunt Bauman trouxe para o imaginário do indivíduo a sensação de conforto, de ordem, resistência e segurança.

A sociedade de consumidores desvaloriza a durabilidade, igualando "velho" a "defasado", impróprio para continuar sendo utilizado e destinado à lata do lixo. [...] antes mesmo de ler, a dependência das compras já se estabelece nas crianças. (BAUMAN, 2008, p.31 e p.73)

Lipovetsky ensina que, a terceira fase do consumismo é o hiperconsumo, e nela já não há limite de idade na atividade de consumo, a criança nessa fase é considerada "hiperconsumidora", e tem poder de escolha, possuindo significativa influência em relação às compras feitas pelos pais. Nos dizeres de Lipovetsky:

A fase III ainda aumentou um grau nessa lógica, exercendo a criança ou o pré-adolescente uma influência cada vez mais importante nas compras efetuadas pelos próprios pais: ele se tornou um comprador-decididor por seu dinheiro para pequenas despesas, ao mesmo tempo que um prescritor de compras pelo novo papel que desempenha em relação aos pais. [...] O filho "mudo" faz parte de uma época finda: na situação atual, ele escolhe, emite solicitações, dá sua opinião por ocasião das compras. [...] Eis-nos na era da 
criança hiperconsumidora, escutada, tendo o direito de fazer as próprias escolhas, dispondo de uma parcela de poder econômico, controlando direta ou indiretamente uma parte das despesas das famílias. (LIPOVETSKY, 2007, p.119-120)

O padrão de consumo da sociedade moderna, atrelada à prática da obsolescência programada $^{31}$ dos produtos, assumiu proporções de grandes impactos ambientais e tornou o resíduo um desafio à população, aos gestores públicos e ao sistema jurídico ambiental (DIAS, 2015).

Essa mudança da sociedade e de seus padrões de consumo trouxe para as crianças mudança em seu estilo de vida e na sua forma de brincar. Com a chegada dos processos produtivos em larga escala, a divulgação do produto deixou de ser tarefa do comércio, direcionado aos publicitários, ao rádio, e à televisão (LEMOS, 2014). Não à toa que anunciantes do setor de brinquedos veicularam mais de 7 mil comerciais no mês que antecedeu o dia das crianças, impactando 36 milhões de pessoas com os anúncios, tendo a palavra "Lego" liderado o ranking com mais de 19 milhões de cliques nos sites de busca (IBOPE, 2016).

As crianças brasileiras estão entre as que mais assistem a televisão no mundo, com média de 5 horas por dia (IBOPE, 2011), e os fatores que mais influenciam o consumo de produtos infantis em geral são: publicidade em TV, personagem famoso e embalagens (Ministério do Meio Ambiente, 2012). Não obstante, os investimentos feitos em TV aberta para anúncios voltados para o "consumidor" infantil, as campanhas de marketing para o público infantil são executadas, predominantemente no Youtube.

Dessa forma, as consequências da publicidade infantil vão na contramão do consumo sustentável, basta uma pesquisa nos vídeos direcionados ao público infantil que é possível verificar a prática constante de unboxing produzidos pelos youtubers mirins, onde as empresas descobriram uma forma de anunciar seus produtos de forma velada, passando despercebido como conteúdo de entretenimento (CATTARUZZI, 2019).

Atrelado ao sucesso dos vídeos "unboxing" (desembrulhar, em português), a empresa MGA Entertainment, percebeu o apelo dessa sensação sobre as crianças e

\footnotetext{
${ }^{31}$ A obsolescência programada se configurou como uma prática mercadológica, em meados do século $\mathrm{XX}$, com o desenvolvimento de lâmpadas de filamento com vida útil reduzida de 2.500 para 1.000 horas propositadamente, com intuito de fomentar o giro de capital e aumentar as vendas das empresas. Essa prática ficou conhecida como primeiro cartel mundial formado pelas empresas OSRAM, Philips, General Eletric e a Companie des Lampes. Em 1933, o escritor Bernard London cunhou o termo em seu livro The New Prosperity.
} 
desenvolveu as bonecas LOL Surprise, um brinquedo com até sete camadas de embalagens, onde o vestuário e adesivos são revelados à medida que é desembrulhada. E essa obsolescência programada combinada com estratégias mercadológicas estimula a criança ao consumo insustentável, causador da degradação da biodiversidade, do aquecimento global, e poluição do ar, solo e água (GOMES, 2015).

O Programa das Nações Unidas para o Meio Ambiente (PNUMA) definiu consumo sustentável como

\begin{abstract}
o fornecimento de serviços e de produtos correlatos, que preencham as necessidades básicas e dêem uma melhor qualidade de vida, ao mesmo tempo em que se diminui o uso de recursos naturais e de substâncias tóxicas, assim como as emissões de resíduos e de poluentes durante o ciclo de vida do serviço ou do produto, com a ideia de não se ameaçar as necessidades das gerações futuras (PNUMA; CETESB, 2005, p.14)
\end{abstract}

É importante lembrar que a publicidade direcionada às crianças é abusiva pois se aproveita da deficiência de julgamento e experiência da criança, tornando-se, portanto proibida, com base no art. 37 do Código de Defesa do Consumidor.

Em 1999, o Brasil adotou a Política Nacional de Educação Ambiental em todo o seu território, através da Lei $\mathrm{n}^{\circ}$. 9795, prevendo o seu desenvolvimento como uma prática educativa integrada, contínua e permanente em todos os níveis e modalidades do ensino formal. Contudo, ainda que as crianças de hoje tenham mais acessos à informação de esgotamento dos recursos naturais, e sua maior consciência em preserválo, foi retirado delas a experiência direta com a natureza.

Para Richard Louv (2016), a falta de contato das crianças com a natureza gera o "transtorno do déficit de natureza" - não trata de um diagnóstico médico - mas define várias questões físicas e mentais que afetam o cotidiano da criança, como a diminuição dos sentidos, agitação, problemas respiratórios e obesidade. Para Louv (2016), "a natureza é um poder civilizador".

Cada vez mais as crianças estão preocupadas e engajadas com o que está acontecendo no planeta. Recentemente, o mundo assistiu aos protestos de milhares de crianças e jovens que participaram do movimento \#youthstrikeclimate, inspirado na ativista climática Greta Thunberg, pressionando governos a adotar ações contra a mudança climática.

$\mathrm{Na}$ Holanda, por exemplo, o governo e alguns programas ensinam a visão da economia circular às crianças, como forma de prepará-los para os desafios globais. Iniciativas como OPEN MINDS OPEN WORLD, (os insights para empresas são estimulados por crianças, onde pequenos e gerentes trabalham juntos pela inovação), e o 
DESIGNATHON SCHOOL (crianças de 4 a 12 anos inventam e constroem soluções para as questões sociais em torno dos Objetivos de Desenvolvimento Sustentável das Nações Unidas), evitará que grandes quantidades de plástico acabem em aterros sanitários e oceanos.

As soluções são variadas e inovadoras, vão desde implementar plataformas e feiras para trocas e aluguel de brinquedos, reciclagem dos brinquedos para novos produtos (como é o caso da empresa ECOBIRDY), incentivar a doação de brinquedos para creches e escolas, até substituir o brinquedo por uma experiência.

\section{AGENDA 2030 PARA O DESENVOLVIMENTO SUSTENTÁVEL}

Os problemas ambientais provenientes da indústria dos brinquedos plásticos não se limitam ao descarte de resíduos. Importante destacar que a produção de novos brinquedos faz uso de recursos naturais, sobretudo de hidrocarbonetos fósseis, altamente poluentes e finitos, e que devido a sua segmentação são produzidos para durar pouco, e serem substituídos mais rapidamente.

No contexto atual brasileiro, a Lei da Política Nacional de Resíduos Sólidos, em seu art. $3^{\circ}$, inciso XIII, coaduna com o art. 225, caput, da Constituição Federal, quando define os padrões sustentáveis de produção e de consumo, propiciando a garantia ao direito ecologicamente equilibrado, essencial à sadia qualidade de vida.

Art. $3^{\circ}$. Para os efeitos desta Lei, entende-se por: XIII - padrões sustentáveis de produção e consumo: produção e consumo de bens e serviços de forma a atender as necessidades das atuais gerações e permitir melhores condições de vida, sem comprometer a qualidade ambiental e o atendimento das necessidades das gerações futuras.

A Política Nacional de Resíduos Sólidos (PNRS), Lei n. 12.305/2010, estabelece no art. 32, que as embalagens devem ser fabricadas com materiais que propiciem a reutilização ou a reciclagem, além da obrigação de estruturar e implementar sistemas de logística reversa, instituto com previsão legal no art. 33. Por sua vez, a Lei 13.186, de 11 de novembro de 2015, instituiu a Política de Educação para o Consumo Sustentável com o objetivo de estimular a adoção de práticas de consumo e de técnicas de produção ecologicamente sustentáveis.

Ademais, a base do desenvolvimento sustentável está na economia circular, geradora de valores de produtos e serviços, mantidos por longo prazo e para todas as partes envolvidas no sistema econômico (CNI, 2018). Para conciliar sustentabilidade e 
produção é preciso sair de uma economia baseada na escassez, de curto prazo e com foco no processo, para uma economia com visão sistêmica.

Em 1972, a Conferência das Nações Unidas sobre o Meio Ambiente Humano, conhecida como Conferência de Estocolmo, trouxe para o centro das discussões ambientais, a finitude dos recursos naturais, e a necessidade de preservá-los para as futuras gerações. Dessa forma, a Constituição Brasileira de 1988, reconheceu como direito fundamental do ser humano o direito ao meio ambiente ecologicamente equilibrado (MILARÉ, 2016).

Em 1986, o termo desenvolvimento sustentável foi utilizado na Conferência Mundial sobre Conservação e Desenvolvimento em Ottawa, tendo como princípios: conservar a natureza e o desenvolvimento, e manter a integridade ecológica (FIORILLO, 2013). Dessa conferência nasceu o Relatório "Nosso Futuro Comum", também conhecido como Relatório Brundtland. Nos termos do Relatório, o desenvolvimento sustentável é aquele que "atende as necessidades do presente sem comprometer a possibilidade de as futuras gerações atenderem a suas próprias necessidades" (1991, p.46).

A expressão foi consagrada e tornou-se princípio na ECO-92, e no entendimento de Luís Paulo Sirvinskas (2018), ele procura conciliar a proteção do meio ambiente com o desenvolvimento socioeconômico para a melhoria da qualidade de vida do homem. É a utilização racional dos recursos naturais não renováveis, também conhecido como meio ambiente ecologicamente equilibrado ou ecodesenvolvimento.

$\mathrm{Na}$ conferência Rio+20, intitulada como "O Futuro que Queremos", foram estabelecidos objetivos ambiciosos, conclamando os Estados-membros da ONU a cumprirem compromissos de ação local e global de forma a atingir metas que orientam para o desenvolvimento sustentável.

A agenda 2030 foi aprovada em setembro de 2015, pela Assembleia Geral da ONU, com o pilar de "não deixar ninguém para trás" e com compromisso mundial de acabar com a pobreza e a fome; combater as desigualdades; proteger os Direitos Humanos das populações mais excluídas e vulneráveis; promover a igualdade de gênero e o empoderamento das mulheres e das crianças; construir sociedades pacíficas, justas e inclusivas; e garantir a proteção duradoura e resiliente do planeta e de seus recursos naturais (PNDU, 2015).

Dentro dos 17 Objetivos para o Desenvolvimento Sustentável (ODS), o ODS 12 assegura padrões de produção e consumo sustentável, de forma que todos os setores 
contribuam para modificar os atuais modos de produção, baseados em padrão linear (extração-produção-consumo-descarte), e adotar medidas e alternativas para minimizar os impactos negativos ambientais e sociais (PNDU, 2015).

O princípio do desenvolvimento sustentável está relacionado diretamente com o direito, a ecologia e a economia, haja vista que, toda decisão política, econômica ou social deverá ter um viés ambiental. No pensamento de Ailton Krenak (2019), durante muito tempo, o conceito de humanidade foi se distanciando da Terra, como se a humanidade não fosse a própria natureza. Nos dizeres de Krenak: "tudo é natureza".

\section{CONSIDERAÇÕES FINAIS}

Esse artigo buscou abordar a trajetória da produção de brinquedos plásticos, que ora se apresenta como potencial para o desenvolvimento infantil, ora se apresenta como estimulador do comportamento de consumo insustentável, trazendo à tona a preocupação com as relações sociais da criança e o meio ambiente.

A indústria de brinquedos tem um enorme caminho a percorrer na luta contra o plástico, e trazer soluções ecológicas para o universo infantil incentivará a cultura do compartilhamento e da colaboração, gerando mudanças necessárias para a sociedade e o meio ambiente (CNI, 2018).

Enquanto a indústria do brinquedo não recorre à matéria-prima biodegradável e alternativas ecológicas é preciso repensar novos modelos de experiências para formação ambiental da criança, a fim de assegurar efetividade da garantia constitucional de proteção ao meio ambiente ecologicamente equilibrado para a presente e futuras gerações.

Dessa forma, percebe-se que envolver a criança de forma lúdica no processo de conscientização ambiental, seja pela brincadeira ao ar livre, seja pelo brinquedo ecológico, trará benefícios para a conservação do planeta ao longo prazo, pois desse processo sairão cidadãos engajados com a causa ecológica. 


\section{REFERÊNCIAS}

ABDI, 2011, RELATÓRIO INDÚSTRIA DE BRINQUEDOS. Agência Brasileira de Desenvolvimento Industrial Disponível em:

https://www3.eco.unicamp.br/neit/images/stories/arquivos/Relatorios_NEIT/Industriade-Brinquedos-Agosto-de-2011.pdf. Acesso em 05 nov. 2020.

ABRELPE, 2018/2019, PANORAMA DOS RESÍDUOS SÓLIDOS NO BRASIL, Associação Brasileira das Empresas de Limpeza Pública e Resíduos Especiais. Disponível em: < https://abrelpe.org.br/download-panorama-2018-2019/>. Acesso em: 20 mar. 2020

ABRINQ, 2020, PANORAMA DOS RESÍDUOS SÓLIDOS NO BRASIL, Associação Brasileira dos Fabricantes de Brinquedos. Disponível em: < http://abrinq.hospedagemdesites.ws/economia-e-estatisticas//>. Acesso 20 mar. 2020.

ATLAS.D-WASTE.COM. Atenas, Grécia. Disponível em < http://www.atlas.dwaste.com/> Acesso em: 01 nov. 2020.

BAUMAN, Zygmunt. Vida para consumo: a transformação das pessoas em mercadorias. Rio de Janeiro: Jorge Zahar, 2008.

BRASIL, Código de Defesa do Consumidor - Lei n. 8.078 de 11 de setembro de 1990.

BRASIL, Política Nacional de Resíduos Sólidos - Lei n. 12.305 de 2 de agosto de 2010.

BRASIL. CONSTITUIÇÃO (1988). Constituição da República Federativa do Brasil. Brasília, DF: Senado Federal: Centro Gráfico, 1988.

BRASIL. Lei no 13.186, de 11 de novembro de 2015. Institui a Política de Educação para o Consumo Sustentável. Diário Oficial da União. Brasília, DF, 12 nov 2015.

BRASIL. Lei no 6.938, de 31 de agosto de 1981. Dispõe sobre a Política Nacional do Meio Ambiente, seus fins e mecanismos de formulação e aplicação, e dá outras providências. Diário Oficial da União. Brasília, DF, 02 set 1981.

BRASIL. Ministério do Meio Ambiente. Lei nº 9.795, de 27/1999. Dispõe sobre a educação ambiental, institui a Política Nacional de Educação Ambiental e dá outras providências. Disponível em: http://www.planalto.gov.br/ccivil_03/leis/19795.htm. Acesso em: 22 set. 2020.

CATTARUZZI, Livia. Criança e Consumo. Unboxing: crianças fora da caixa. 2019. Disponível em: https://criancaeconsumo.org.br/noticias/unboxing-criancas-fora-dacaixa/. Acesso em 10 set 2020.

CHAMAS, A. et al. Degradation Rates of Plastics in the Environment. ACS Sustainable Chemistry \& Engineering, v.08, n. 09, mar. 2020. Disponível em: <https://pubs.acs.org/doi/10.1021/acssuschemeng.9b06635\# > Acesso em: 01 nov. 2020. 
CONFEDERAÇÃO NACIONAL DA INDÚSTRIA. Economia circular: oportunidades e desafios para a indústria brasileira / Confederação Nacional da Indústria. - Brasília: CNI, 2018.

CORDAZZO, Scheila Tatiana Duarte; VIEIRA, Mauro Luís. A brincadeira e suas implicações nos processos de aprendizagem e de desenvolvimento. Estudos e Pesquisas em Psicologia, Rio de Janeiro, v. 7, n. 1, jun. 2007 . Disponível em $<$ http://pepsic.bvsalud.org/scielo.php? script=sci_arttext\&pid=S180842812007000100009\&lng=pt\&nrm=iso>. acessos em 01 nov. 2020.

DIAS, Sylmara Gonçalves. Consumo e Resíduos: Duas Faces da Mesma Moeda. Revista

FIORILLO, Celso Antonio Pacheco. Curso de direito ambiental brasileiro. 14. ed. São Paulo : Saraiva, 2013.

GEYER, R. et al. Production, use, and fate of all plastics ever made. Science Advances, v. 3, n. 7, jul. 2017. Disponível em: <

https://advances.sciencemag.org/content/3/7/e1700782> Acesso em: 10 Out 2020.

GPQV/UFSCar, 2020. Infância Plastificada. Disponível em: < https://criancaeconsumo.org.br/wp-content/uploads/2020/06/cc_infanciaplastificada.pdf >. Acesso em 10 set. 2020.

IBOPE. Disponível em: < https://www.kantaribopemedia.com/anunciantes-do-setorbrinquedos-e-acessorios-veicularam-mais-de-7-mil-comerciais-no-mes-que-antecedeuo-dia-das-criancas-2/> . Acesso em: 27 set. 2020.

INMETRO: REGULAMENTO TÉCNICO MERCOSUL SOBRE SEGURANÇA EM BRINQUEDOS Inmetro. Rio de Janeiro, junho 2005. Disponível em < http://www.inmetro.gov.br/rtac/pdf/RTAC000946.pdf>. Acesso em 07 nov 2020.

INTERSCIENCE. Como atrair o consumidor infantil, atender expectativas dos pais e ainda ampliar as vendas. Programa Criança e Consumo, 2003. Biblioteca. Disponível em: http:// 99 criancaeconsumo.org.br/biblioteca/como-atrair-o-consumidorinfantilatender-expectativas-dos-pais-e-ainda-ampliar-asvendas/. Acesso em: 28 set. 2020.

KRENAK, Ailton. Ideias para adiar o fim do mundo. São Paulo: Companhia das Letras. 2019.

LEMOS, Patrícia Fraga Iglecias. Resíduos sólidos e responsabilidade pós-consumo. $3^{\circ}$ ed. São Paulo: Editora Revista dos Tribunais, 2014.

LIPOVETSKY, Gilles. A FELICIDADE PARADOXAL: ensaio sobre a sociedade de hiperconsumo. São Paulo: Companhia das Letras, 2007.

LOUV, Richard. A última criança na natureza: resgatando nossas crianças do transtorno do déficit de natureza. 1. ed. São Paulo: Aquariana, 2016. Mestrado PUCSP. 
MARTÍN, María. EL PAÍS. A geração que não assiste mais TV e corre atrás dos 'youtubers', 2017. Disponível em: < https://brasil.elpais.com/brasil/2017/08/13/tecnologia/1502578288_835104.html>. Acesso em 10 out. 2020.

MILARÉ, Édis. Reação Jurídica à Danosidade Ambiental: Contribuição para o delineamento de um microssistema de responsabilidade. São Paulo: Tese de Doutorado em Direito, PUC-SP, 2016.

MINISTÉRIO DO MEIO AMBIENTE. Cadernos de Consumo Sustentável. Consumismo infantil: na contramão da sustentabilidade, 2012. Disponível em: < https://www.mma.gov.br/images/publicacoes/responsabilidade_socioambiental/produca o_consumo/caderno_crianca_e_consumo_sustentavel_completo.pdf $>$. Acesso em 16 ago 2020 .

Nosso Futuro Comum. Comissão Mundial sobre o Meio Ambiente e Desenvolvimento, $2^{\text {o }}$ ed. FGV, Rio de Janeiro: 1991.

PIATTI, T.M.; RODRIGUES, R.A. Plásticos: características, usos, produção e impactos ambientais. Maceió: EDUFAL, 2005. Disponível em:

$<$ http://www.usinaciencia.ufal.br/multimidia/livros-digitais-

cadernostematicos/Plasticos_caracteristicas_usos_producao_e_impactos_ambientais.pdf > Acesso em: 10 Out. 2020.

PINTO, J.C. et al. Impactos ambientais causados pelos plásticos - Uma discussão abrangente sobre os mitos e os dados científicos. Ed. 2 Rio de Janeiro: E-papers, 2012.

PLASTICS LE MAG. Christmas: plastic toys in vogue. Plastics le Mag, 23 nov. 2011. Daily Life. Disponível em: http:// 104 plastics-themag.com/Plastic-shakes-up-the-toyindustry. Acesso em: 18 out. 2020.

PNUMA - Programa das Nações Unidas para o Meio Ambiente. A produção mais limpa e o consumo sustentável na América Latina e Caribe, 2004. São Paulo: PNUMA; CETESB, 2005. Disponível em: $<$ https://cetesb.sp.gov.br/consumosustentavel/wpcontent/uploads/sites/20/2013/11/pl_portugues.pdf>. Acesso em: 18 out.2020.

RAHN, Wesley. Estudo na Alemanha acha plástico em organismo de crianças. DW, 14 set. 2019. Notícias, Ciência e Saúde. Disponível em: https://www.dw.com/ptbr/estudona-alemanha-acha-p1\%C3\%A1 stico-em-organismo-decrian\%C3\%A7as/a50434831. Acesso em: 03 out. 2020.

SIRVINSKAS, Luís Paulo. Manual de direito ambiental. 16. ed. São Paulo : Saraiva Educação, 2018.

UNENVIRONMENT.ORG. Disponível em: < https://www.unenvironment.org/interactive/beat-plastic-pollution/> . Acesso em 15 Out. 2020.

VYGOTSKY, L. S. A formação social da mente. São Paulo: Martins Fontes, 1988. 
WWF, 2019, SOLUCIONAR A POLUIÇÃO PLÁSTICA: TRANSPARÊNCIA E RESPONSABILIZAÇÃO. Disponível em: https://d335luupugsy2.cloudfront.net/cms/files/51804/1552932397PLASTIC_REPORT _02-2019_Portugues_FINAL.pdf>. Acesso em 10 nov. 2020.

ZALASIEWICZ, J. et al. The geological cycle of plastics and their use as a stratigraphic indicator of the Anthropocene. ELSEVIER, v. 13, n. , mar. 2016. Disponível em: <https://www.sciencedirect.com/science/article/abs/pii/S2213305416300029?via\%3Dih ub > Acesso em 5 Out. 2020.

ZINI, Josiane et al. Estudo de metais e de substâncias tóxicas em brinquedos. Química Nova, São Paulo, v. 32, n. 4, p. 833-838, 2009. Disponível em: http://www.scielo.br/scielo.php?script=sci_arttext\&pid=S0100-40422009000400002. Acesso em: 01 nov. 2020. 


\title{
A EDUCAÇÃO AMBIENTAL E GESTÃO EFICIENTE DAS POLÍTICAS PÚBLICAS DE RESÍDUOS MUNICIPAIS: OS EXEMPLOS DE SALVADOR E FLORIANÓPOLIS
}

\author{
Maria Isabelle dos Santos Guimarães Souza ${ }^{32}$
}

Josiene Nunes de Oliveira ${ }^{33}$

A problemática do gerenciamento de resíduos tem sido pauta nas políticas públicas nacionais e internacionais durante muito tempo. No entanto, atualmente, as questões ambientais ligadas a esta seara se tornaram temáticas obrigatórias na agenda mundial, especialmente pela urgência de resultados eficazes.

Nesse patamar, a Agenda 2030 para o desenvolvimento sustentável surgiu como uma aliada na busca por tais mudanças. Trata-se de um plano de ação adotado na Assembleia da Organização das Nações Unidas (ONU) em 2015, oportunidade em que foram apresentados os resultados alcançados até aquele momento, bem como instituídas metas que devem ser alcançadas até o ano de 2030. Por esse motivo, os 17 objetivos do desenvolvimento sustentável (ODS) foram criados como uma forma de auxiliar os países participantes da referida agenda em busca de alcançar as metas já estabelecidas anteriormente.

No entanto, apesar dos esforços para se alcançar tais objetivos, alguns exemplos no Brasil têm demonstrado como o enfrentamento a essas questões não têm produzido o retorno esperado. Diante disso, o presente artigo se desenvolverá a partir das ODS 04 e

\footnotetext{
32 Advogada.Pós-graduanda em Direito Público, pela Universidade Salvador(UNIFACS).Graduada em Direito pela Universidade Estadual da Bahia(UNEB). Integrante do grupo Direito Ambiental e Resíduos Sólidos em uma perspectiva local e internacional na Liga Acadêmica de Estudos Jurídicos da Bahia(LAEJU-BA).E-mail: mariaisabellegss@gmail.com.

${ }^{33}$ Pós-graduada em Direito Público,pela Universidade Salvador(UNIFACS).Pós-graduanda em Direito Ambiental pela Faculdade Descomplica.Bacharel em Direito pelo Instituto Baiano de Ensino Superior(IBES). Integrante do Direito Ambiental e Resíduos Sólidos em uma perspectiva local e internacional na Liga Acadêmica de Estudos Jurídicos da Bahia (LAEJU-BA). E-mail: enenunes@gmail.com.
} 
17, quais sejam, a educação de qualidade e a parceria e meios de implementação, de modo a demonstrar como é essencial pensar na educação ambiental de qualidade no momento da elaboração de políticas públicas ambientais para conferir a eficiência que se espera das referidas políticas.

Para tanto, serão utilizados os exemplos do Imposto Predial e Territorial Urbano (IPTU) Verde do município de Salvador, pelo Decreto $\mathrm{n}^{\circ} 29.100$, de 06 de novembro de 2017 e a Lei $\mathrm{n}^{\circ}$ 10.501/2019, criada pelo município de Florianópolis, como forma de demonstrar como à eficiência das políticas públicas está intimamente ligada ao estímulo à educação ambiental.

\title{
2 POLÍTICAS PÚBLICAS AMBIENTAIS NO BRASIL: BREVE TRAJETÓRIA
}

Baseado na perspectiva da ciência política, e de acordo com as problemáticas levantadas, o estudo das políticas públicas costuma ser abordado a partir de três vertentes.

\begin{abstract}
A primeira, refere-se ao questionamento clássico da ciência política, no qual indaga-se se a ordem política é certa ou verdadeira a partir do sistema político vigente; na segunda, tem-se o questionamento político propriamente dito, que se refere à análise das forças políticas cruciais no processo decisório; por fim, a terceira, se baseia no resultado que determinado sistema político produz (FREY, 2000, p. 213).
\end{abstract}

O estudo das políticas públicas, como qualquer outro, se remodela de acordo com as necessidades emergentes, de modo que, seja agregada por outras áreas, como o Direito. À vista disso, convém esclarecer que o conceito de políticas públicas é plural. Dessa forma, neste artigo, entende-se por políticas públicas projetos e iniciativas aplicados pelos entes públicos com a intenção de promover os direitos da pessoa humana. Referidas conceituações, apesar de possuírem abordagens diferentes, assumem, em geral, uma visão holística do tema, sob a ótica de que "o todo é mais importante do que a soma das partes e que indivíduos, instituições, interações, ideologia e interesses contam, mesmo que existam diferenças sobre a importância relativa destes fatores" (SOUZA, 2006, p. 25).

Entender a origem de um ramo de estudo é fundamental para compreensão dos seus desdobramentos, trajetórias e perspectivas. No Brasil, a origem das políticas públicas baseou-se em um contexto autoritário e conservador, onde tudo se concentrava ao redor do Estado. Sobre o assunto, Brasil e Capella (2016, p. 79), esclarece que 
“entender a valorização e a consolidação das políticas públicas no Brasil está diretamente vinculado aos processos de descentralização e de gerenciamento, típicos da Reforma Administrativa ocorrida no Brasil em meados dos anos 1990".

A nova configuração do Estado, após o fim da ditadura militar e o processo de redemocratização, foi aliada na formação do campo de políticas públicas. A instituição do Estado Mínimo, com os ideais de maior liberdade dos indivíduos e menor interferência do Estado, auxiliou na consolidação da democracia e da cidadania, ao modificar a relação entre o Estado e a sociedade. Segundo Brasil e Capella (2016), as mudanças também trouxeram consigo a gestão das políticas públicas. A reforma administrativa, ao reordenar internamente a administração pública, alterou o modo como o Estado se posicionava e produzia políticas públicas,facilitando a sua criação tendo em vista, a partir desse momento, buscou-se torná-las mais efetivas, de modo a alcançar os resultados esperados.

Nesse ponto, vê-se que a questão da falta de efetividade das políticas públicas não é pauta nova nas demandas da sociedade. Segundo Brasil e Capella (2016, p. 85), o estudo das políticas públicas no Brasil obteve um impulso, especialmente no que se refere às políticas sociais e de participação e, à vista disso, foram estabelecidas novas formas de atuação e direcionamento na análise das políticas.

A evolução histórica do estudo das políticas públicas também refletiu na implementação das políticas ambientais no Brasil. De acordo com Salheb et al. (2009, p. 08), o primeiro momento da política ambiental brasileira foi marcado por duas preocupações básicas: a racionalização do uso e exploração dos recursos naturais e a definição de áreas de preservação permanente, estabelecendo, assim, alguns limites à propriedade privada. Nesse patamar, é importante esclarecer que no Brasil, a economia predominantemente exploratória refletiu na utilização dos recursos e riquezas naturais de modo predatório, o que ocorre até os dias atuais.

Salheb et al. (2009, p. 13), menciona que desde o período colonial até a época da ditadura militar, entre os anos de 1960 e 1970, a política nacional buscava "integrar para não entregar", tendo em vista os vazios demográficos, pela extensão do país, e a necessidade de ocupar a Amazônia a qualquer custo. A partir das primeiras décadas do século XX, a legislação brasileira já possuía um mínimo arcabouço jurídico no que tange a proteção ambiental, no entanto, demonstravam ineficiência frente aos interesses econômicos do Poder Público da época. No período entre os anos 1970 e 1980, adotouse políticas ambientais de proteção e conservação, baseando-se na busca do 
desenvolvimento sustentável, a partir da criação de diversas legislações. Entre elas, a lei $\mathrm{n}^{\circ}$ 6.938/1981, que instituiu a Política Nacional do Meio Ambiente, recepcionada pela Constituição Federal.

No decorrer dessa trajetória, a instituição de políticas ambientais no Brasil demonstrou uma maior emergência, impulsionadas especialmente pelos eventos internacionais, bem como pelo fato de a busca por um desenvolvimento sustentável se tornar uma das principais metas do poder público.

No âmbito internacional, durante os anos 1990, iniciou-se um debate pela Cúpula das Nações Unidas acerca do desenvolvimento humano, o que culminou, nos anos 2000, no surgimento da Declaração do Milênio e a criação de oito objetivos a serem alcançados em 15 anos, se tornando o primeiro arcabouço global de políticas para o desenvolvimento. Em 2010, observou-se a necessidade de implementação dos Objetivos, oportunidade em que se iniciou a elaboração de novas recomendações acerca dos próximos passos após o ano de 2015. Dessa forma, em 2015, a Assembleia Geral da ONU adotou a Agenda 2030, um plano de ação internacional para a garantia do desenvolvimento sustentável para todos, até o ano de 2030. Nessa oportunidade, foram criados os 17 objetivos do desenvolvimento sustentável e 169 metas para serem alcançadas pelos países até o ano de 2030.

No Brasil, enquanto ocorria as referidas discussões, foi criada a Lei $n^{\circ}$ 12.305/2010, um marco no Direito Ambiental brasileiro, que instituiu a Política Nacional de Resíduos Sólidos (PNRS), ao dispor sobre princípios, objetivos, instrumentos, diretrizes e responsabilidades, no gerenciamento de resíduos sólidos, se tornou um marco na legislação ambiental do Brasil, bem como uma aliada na implementação das políticas públicas ambientais.

Uma vez definido em legislação específica como deve ser desenvolvida as ações relacionadas à gestão integrada ou ao gerenciamento de resíduos sólidos, tornando responsável não só o Poder Público, mas a Sociedade em geral, o trato com a pauta dos resíduos se torna mais acessível e aberto tanto às cobranças por parte dos cidadãos, como as responsabilizações por parte do Poder Público. 


\section{A EDUCAÇÃO AMBIENTAL COMO INSTRUMENTO DE POLÍTICASPÚBLICAS}

A Educação Ambiental é um eficaz instrumento para que se possa conscientizar a população acerca da importância da preservação e manutenção dos recursos ambientais. O artigo 225, da Constituição Federal de 1988, elevou o meio ambiente a um status de direito fundamental, ao prever que o meio ambiente ecologicamente equilibrado é um bem de uso comum do povo e essencial para uma saudável qualidade de vida. Ademais, impôs ao Poder Público e à coletividade o dever de defendê-lo e preservá-lo para as presentes e futuras gerações.

Para assegurar a efetividade do direito ao meio ambiente ecologicamente equilibrado, a Constituição Federal atribuiu ao Poder Público o dever de promover a educação ambiental em todos os níveis de ensino e a conscientização pública para a preservação do meio ambiente. Nesse viés, é importante comentar sobre o princípio da participação, também previsto no artigo 225 da Constituição Federal, que impôs também à coletividade o dever de defender e preservar o meio ambiente para as presentes e futuras gerações. Referido princípio também está previsto na Declaração RIO 92, em seu princípio ${ }^{\circ} 10$ :

\footnotetext{
A melhor maneira de tratar questões ambientais é assegurar a participação, no nível apropriado, de todos os cidadãos interessados. No nível nacional, cada indivíduo deve ter acesso adequado a informações relativas ao meio ambiente de que disponham autoridades públicas, inclusive informações sobre materiais e atividades perigosas em suas comunidades, bem como a oportunidade de participar em processos de tomada de decisões. Os Estados devem facilitar e estimular a conscientização e a participação pública, colocando a informação à disposição de todos. Deve ser propiciado acesso efetivo a mecanismos judiciais e administrativos, inclusive no que diz respeito à compensação e reparação de danos.
}

É imensurável a importância da educação ambiental, podendo ser ela considerada um instrumento ao qual se pode, ou pelo menos almeja alcançar, a conscientização ambiental. Esta última, aliada à participação ambiental, é fundamental para a preservação do meio ambiente. É justamente essa busca em promover uma maior conscientização ambiental que no ano de 1999 instituiu-se a Política Nacional de Educação Ambiental.

Com a crescente poluição resultante da grande quantidade de resíduos produzidos e os impactos ambientais provenientes destes, surgiu a necessidade do gerenciamento de resíduos. Após 20 anos de tramitação no Congresso Nacional, no ano de 2010, entrou em vigor a Lei $n^{\circ}$ 12.305/10 que instituiu a Política Nacional de 
Resíduos Sólidos (PNRS). Esta, trouxe em seu bojo, uma série de princípios, objetivos, instrumentos, diretrizes, metas e ações a serem adotadas pelo Governo Federal, de forma isolada e/ou em cooperação com Municípios, Distrito Federal, Estados ou particulares, em busca de um gerenciamento e gestão ambiental adequada dos resíduos sólidos.

$\mathrm{O}$ artigo $3^{\circ}$ da PNRS tratou de conceituar diversos institutos associados à referida Política. Entre eles, destacam-se as seguintes definições:

\footnotetext{
VII - destinação final ambientalmente adequada: destinação de resíduos que inclui a reutilização, a reciclagem, a compostagem, a recuperação e o aproveitamento energético ou outras destinações admitidas pelos órgãos competentes do Sisnama, do SNVS e do Suasa, entre elas a disposição final, observando normas operacionais específicas de modo a evitar danos ou riscos à saúde pública e à segurança e a minimizar os impactos ambientais adversos;

$\mathrm{X}$ - gerenciamento de resíduos sólidos: conjunto de ações exercidas, direta ou indiretamente, nas etapas de coleta, transporte, transbordo, tratamento e destinação final ambientalmente adequada dos resíduos sólidos e disposição final ambientalmente adequada dos rejeitos, de acordo com plano municipal de gestão integrada de resíduos sólidos ou com plano de gerenciamento de resíduos sólidos, exigidos na forma desta Lei;

$\mathrm{XV}$ - rejeitos: resíduos sólidos que, depois de esgotadas todas as possibilidades de tratamento e recuperação por processos tecnológicos disponíveis e economicamente viáveis, não apresentem outra possibilidade que não a disposição final ambientalmente adequada;

XVI - resíduos sólidos: material, substância, objeto ou bem descartado resultante de atividades humanas em sociedade, a cuja destinação final se procede, se propõe proceder ou se está obrigado a proceder, nos estados sólido ou semissólido, bem como gases contidos em recipientes e líquidos cujas particularidades tornem inviável o seu lançamento na rede pública de esgotos ou em corpos d'água, ou exijam para isso soluções técnica ou economicamente inviáveis em face da melhor tecnologia disponível;
}

Segundo o autor Frederico Amado (2014 e p.868), o objetivo principal da PNRS é a proteção da saúde pública e da qualidade ambiental, pois ao fazer um descarte ambientalmente correto, minimizam-se os danos sofridos pelo Meio Ambiente.

A Política Nacional de Educação Ambiental (PNEA), instituída pela Lei $n^{\circ}$ 9.795/99, aliada à PNRS é um importante instrumento para a concretização dos objetivos trazidos por esta última. Segundo o artigo $1^{\circ}$ da PNEA, entende-se por educação ambiental "os processos por meio dos quais o indivíduo e a coletividade constroem valores sociais, conhecimentos, habilidades, atitudes e competências voltadas para a conservação do meio ambiente". Nesse viés, no que tange à gestão de resíduos sólidos, a Educação Ambiental tem como objetivo aprimorar conhecimento, valores, comportamentos e estilo de vida que, juntos, contribuem para um adequado e eficaz gerenciamento. Apresenta objetivos fundamentais tais como,desenvolver uma 
compreensão integrada do meio ambiente, com múltiplas relações, envolvendo aspectos diversos, como éticos, sociais, legais, ecológicos, garantir à população informações, conscientizar sobre os problemas ambientais.

Ademais, com a finalidade de estabelecer normas de proteção ambiental, foi criada a Lei 6.938/81 que instituiu a Política Nacional do Meio Ambiente (PNMA), recepcionada pela Constituição de 1988. A PNMA é a referência mais importante no que se refere a assuntos ambientais após a CRFB/88. Pois, além de trazer instrumentos e princípios, possui como objetivo a busca da preservação, melhoria e recuperação da qualidade ambiental. Nesse patamar, um dos princípios elencados na PNMA é a previsão de educação ambiental a todos os níveis de ensino, inclusive a educação da comunidade, objetivando capacitá-la para participação ativa na defesa do meio ambiente.

Embora a PNEA reconheça a educação ambiental como um componente essencial e permanente da educação nacional, devendo estar presente, de forma articulada, em todos os níveis e modalidades da educação, em caráter formal e nãoformal, foi vetada pela Lei 9394/1996 que estabelece as bases e diretrizes da educação nacional.

Isto posto, é inegável que o Brasil possui um aparato legal admirável no que tange o gerenciamento de resíduos, tanto pelo trato minucioso - tendo em vista que lida com grande parte das problemáticas ambientais a seu respeito -, quanto pelo arcabouço de diretrizes, objetivos e fundamentos que trazem em seus bojos. No entanto, conforme será exposto, frequentemente não são utilizados pelo Poder Público da maneira mais eficaz.

\section{A IN(EFICIÊNCIA) DAS POLÍTICAS PÚBLICAS AMBIENTAIS E O INCENTIVO À EDUCAÇÃO AMBIENTAL}

Não obstante, o Brasil possua amparo legal minucioso para lidar com a problemática dos resíduos sólidos, ainda há muito a se alcançar, especialmente no que se refere à efetivação da educação ambiental como instrumento da Política Nacional de Resíduos Sólidos. E isto, de tal modo, reflete na elaboração das políticas públicas implantadas pelo Estado que tem o escopo de tentar impedir ou diminuir os prejuízos causados ao meio ambiente pelo não gerenciamento adequado dos resíduos. 


\title{
4.1 O EXEMPLO DE IPTU VERDE VERSUS A LEI DA COMPOSTAGEM
}

O IPTU Verde foi instituído na cidade de Salvador pelo Decreto ${ }^{\circ} 29.100$, de 06 de novembro de 2017, tendo como objetivo "incentivar empreendimentos que contemplem ações e práticas sustentáveis destinadas à redução do consumo de recursos naturais e redução dos impactos ambientais" (SALVADOR, 2017).

Trata-se de uma certificação opcional, direcionada a novos empreendimentos a serem edificados, assim como ampliações e/ou reformas de edificações existentes de uso residencial, comercial, misto, institucional e industrial. $\mathrm{O}$ referido decreto estabelece ações e práticas de sustentabilidade a ser seguida pelos interessados, a fim de que alcancem uma pontuação, conforme estabelece o artigo $2^{\circ}$ :

\begin{abstract}
Art. $2^{\circ}$ A certificação IPTU VERDE será obtida pelo empreendimento que adotar ações e práticas de sustentabilidade relacionadas no ANEXO I, correspondendo cada ação à pontuação ali estabelecida, da seguinte forma: I o empreendimento que atingir, no mínimo, 50 (cinquenta) pontos será classificado como BRONZE; II - o empreendimento que atingir, no mínimo, 70 (setenta) pontos será classificado como PRATA; III - o empreendimento que atingir, no mínimo, 100 (cem) pontos será classificado como OURO.
\end{abstract}

A partir das classificações acima, são concedidos descontos no IPTU das edificações, conforme dispõe o artigo $10^{\circ}$ do referido Decreto:

Art. 10. Será concedido desconto na cobrança do IPTU para todas as unidades imobiliárias autônomas que compõem a edificação, da seguinte forma: I - desconto de 5\% (cinco por cento), quando houver a certificação BRONZE; II - desconto de 7\% (sete por cento), quando houver a certificação PRATA; III - desconto de $10 \%$ (dez por cento), quando houver a certificação OURO.

Ao final do Decreto há o Anexo I, no qual constam 70 itens contendo as ações e práticas de sustentabilidade para se alcançar os descontos no IPTU. Entre eles, há um tópico intitulado de "Central de resíduos com compartimentos para coleta seletiva", que propõe ações relacionadas aos resíduos produzidos no local.

De fato, da análise superficial do aludido Decreto as ações propostas são de grande valia, tendo em vista que propõe inserção da sustentabilidade nas edificações, reformas e ampliações do município. No entanto, em se tratando do manejo dos resíduos, vê-se que se trata apenas de ações mitigadoras. São elas: espaço ventilado e de fácil acesso com revestimento em material lavável e ponto de água; resfriamento de casa de lixo; trituradores de papel e papelão; compactadores de lixo; trituradores de pia de cozinha em $90 \%$ dos pontos; parcerias com cooperativas cadastradas no Município. 
Em contrapartida, a Lei $\mathrm{n}^{\circ} 10.501 / 2019$, instituiu no âmbito do município de Florianópolis a obrigatoriedade da destinação ambientalmente adequada de resíduos sólidos orgânicos por meio dos processos de reciclagem e compostagem. Segundo o parágrafo único, artigo $2^{\circ}$, da referida lei, aplica-se à obrigatoriedade as "pessoas jurídicas, de direito público ou privado responsáveis, direta ou indiretamente, pela geração de resíduos e as que desenvolvam ações relacionadas à gestão integrada ou ao gerenciamento de resíduos sólidos" (FLORIANÓPOLIS, 2019).

Ademais, a lei prevê a vedação à destinação de resíduos orgânicos em aterros sanitários e à incineração, excetuando-se apenas em caso de calamidade pública, estado de emergência ou paralisação dos trabalhadores da Autarquia Companhia Melhoramentos da Capital (COMCAP) superior a três dias. Prevê, ainda, um cronograma de adesão às pessoas jurídicas de Direito Público e Privado, de modo que tenham tempo para se adaptar às regras instituídas. Por fim, estabelece diretrizes para que o Poder Executivo destine áreas de sua propriedade para realização da compostagem, com base nas especificações técnicas, bem como à adoção, incentivo e estímulos na implantação da referida gestão de resíduos.

De antemão, o que se depreende da análise do Decreto $n^{\circ} 29.100$ e da Lei ${ }^{\circ}$ 10.501/2019, é que, esta última, trata a esfera dos resíduos sólidos do modo como se espera que seja uma política pública ambiental desta seara, enfrentando os problemas ambientais de forma não apenas atenuante, mas sim, para promover mudanças substanciais no manejo dos resíduos.

Durante muito tempo a problemática do gerenciamento dos resíduos sólidos era focada apenas na sua disposição final, sem se considerar o seu manejo, que compreende fases de coleta, transporte, acondicionamento, tratamento, planejamento, fiscalização e regulamentação. No entanto, as adversidades encontradas, especialmente na esfera dos danos ambientais e à saúde pública, demonstraram a necessidade de se aperfeiçoar a referida gestão. Inequívoco que grande parte dessa mudança surgiu a partir da compreensão da educação ambiental como instrumento das políticas públicas.

Para que haja eficácia no gerenciamento de resíduos é necessário que todos os indivíduos tenham ciência da sua importância em todo o processo. A Política Nacional de Educação Ambiental traz justamente essa ideia à legislação ambiental, sendo, inclusive, o incentivo à participação individual e coletiva um dos objetivos fundamentais da educação ambiental. Nesse viés, considerando que a Política Nacional de Educação Ambiental conferiu ao Poder Público o dever de "definir políticas 
públicas que incorporem a dimensão ambiental, promover a educação ambiental em todos os níveis de ensino e o engajamento da sociedade na conservação, recuperação e melhoria do meio ambiente" (BRASIL, 1999), então cabe ao mesmo articular e incentivar as políticas públicas ambientais que sejam realmente eficazes.

Ao comparar o Decreto do IPTU Verde implantado no município de Salvador e a lei que instituiu a obrigatoriedade da reciclagem e compostagem no município de Florianópolis, observa-se que este último fundamenta-se na necessidade de conscientização ambiental por parte dos munícipes, tendo em vista que, para conseguirem cumprir o que Lei preceitua, precisam no mínimo compreender o que é, a importância e técnicas de compostagem e reciclagem. Dessa forma, ao instituir referida política pública - especialmente por torná-las obrigatórias -, o município induziu pessoas jurídicas de direito público e privado a buscarem conscientização.

Em contrapartida, a Política Pública instituída através do IPTU Verde, no que tange a problemática de resíduos, apresenta em seu bojo apenas ações práticas que não condizem com o necessário estímulo à educação ambiental nas políticas públicas municipais. Enquanto o Poder Público não compreender que estimular práticas ambientalmente eficazes deve ser base para instituição de políticas públicas e, que a falta de educação ambiental é a resposta para a ineficácia ou pouco resultado das políticas já existentes, os municípios continuarão a produzir resíduos em larga escala, sem se preocupar com o amanhã.

\section{CONSIDERAÇÕES FINAIS}

O homem é o maior agente transformador na natureza, sendo responsável por grandes e significativos impactos. Tais mudanças não possuem sempre caráter positivo e, em alguns casos, não há nenhuma possibilidade de reversão. Dessa forma, para manutenção do meio ambiente ecologicamente equilibrado, conforme preceitua o artigo 225, da Constituição Federal, é necessário a criação de uma conscientização ambiental, que contenha, precipuamente, um desejável consumo consciente, servindo-se da sustentabilidade e da compreensão da finitude dos recursos ambientais.

Para tanto, a educação ambiental é considerada o meio mais importante na tarefa de ensinar ao homem a necessidade de preservação dos recursos ambientais. No que tange ao gerenciamento de resíduos, a busca pelo consumo sustentável deve estar aliada ao seu correto descarte. Ademais, não se pode esquecer que os resíduos são 
considerados bens de consumo, pois o "lixo" é fonte de subsistência de inúmeras famílias. O homem precisa aprender a lidar com os resíduos de forma correta, visando um menor impacto ambiental.

Diante disso, as políticas ambientais não devem ser consideradas apenas como um instrumento para punição pelo dano ambiental promovido. É imprescindível que seja também utilizada para prevenção, conforme preceitua a própria PNRS e também os tributos ambientais que visam estimular a defesa e preservação ambiental. Embora tenhamos legislações que busquem incentivar a Educação Ambiental, ela não é de fato incentivada e aplicada como se faz necessário. Os exemplos estabelecidos no referido artigo demonstraram como, apesar do arcabouço legislativo no que tange ao gerenciamento de resíduos e educação ambiental, e a tributação ambiental que busca incentivar a defesa e preservação ambiental,os municípios nem sempre assumem a direção que estes preceituam quando no momento de criação de políticas públicas ambientais.

Como afirma o ilustre Paulo Freire, a Educação não transforma o mundo. A Educação muda pessoas. Pessoas transformam o mundo, e é através delas que podemos conscientizar ecologicamente a população.Para mudar e transformar, que se aplique de fato uma educação ambiental, como um meio transformador, que se insira e trabalhe realmente nas escolas, como pauta essencial e não uma matéria extracurricular optativa. Com uma educação ambiental associada a um saneamento básico, o Brasil poderá alcançar equilíbrio ambiental.

\section{REFERÊNCIAS}

AMADO, Frederico Augusto di Trindade. Ambiental. Rio de Janeiro: Forense; São Paulo: MÉTODO, 2015.

ANTUNES, Paulo de Bessa. Direito Ambiental. 20. ed. - São Paulo: Atlas, 2019.

BRASIL, F. G.; CAPELLA, A. C. N. Os Estudos das Políticas Públicas no Brasil: Passado, Presente e Caminhos Futuros da Pesquisa sobre Análise de Políticas. Revista Política Hoje, vol. 25, n. 1, 2016, p. 71-90.

BRASIL, Nações Unidas. Objetivos de desenvolvimento sustentável. Disponível em: https://brasil.un.org/pt-br/sdgs. Acesso em: 12 de setembro de 2020. 
BRASIL. Política Nacional de Educação Ambiental, Lei 9795. Diário Oficial da República Federativa do Brasil, Brasília, DF, 27 abr. 1999. Disponível em: <http://www.planalto.gov.br/ccivil_03/leis/19795.htm > Acesso em: 20 de out. de 2020.

EIGENHEER, Emílio Maciel. A história do lixo: A limpeza urbana através dos tempos. Rio de Janeiro: Editora Campus: 2009.

FLORIANO, Eduardo Pagel. Políticas de gestão ambiental, 3 ed. Santa Maria: UFSMDCF, 2007.

FLORIANÓPOLIS. Lei $\mathbf{N}^{\mathbf{0}} \mathbf{1 0 . 5 0 1}$, de 08 de abril de 2019. Dispõe sobre a obrigatoriedade da reciclagem de resíduos sólidos orgânicos no Município de Florianópolis: Câmara Municipal. 2018. Acesso em:

$<$ https://leismunicipais.com.br/a/sc/f/florianopolis/lei-ordinaria/2019/1051/10501/leiordinaria-n-10501-2019-dispoe-sobre-a-obrigatoriedade-da-reciclagem-de-residuossolidos-organicos-no-municipio-de-florianopolis>

FREY, Klaus.Políticas Públicas: um debate conceitual e reflexões referentes à prática da análise de políticas públicas no Brasil. Planejamento de Políticas Públicas, n. 21, 2000. Disponível em:

<https://www.ipea.gov.br/ppp/index.php/PPP/article/view/89/158>Acesso em:09/11/2020.

MEDEIROS,M.C;RIBEIRO,M.C.M;FERREIRA,C.M.A. Meio ambiente e educação ambiental nas escolas públicas. Disponível em

$<$ https://ambitojuridico.com.br/cadernos/direito-ambiental/meio-ambiente-e-educacaoambiental-nas-escolas-publicas/> .Acesso em:09/11/2020.

OLIVEIRA, Fabiano Melo Gonçalves de. Direito ambiental. 2. ed. rev., atual. e ampl. - Rio de Janeiro: Forense; São Paulo: MÉTODO, 2017.

ROCHA, Marcelo Borges et e al. Educação Ambiental na Gestão de Resíduos Sólidos: concepções e práticas de estudantes do Curso Superior de Tecnologia em Gestão Ambiental. Revista de Educação Ambiental, vol. 17, n. 1, 2012. Disponível em: <https://periodicos.furg.br/ambeduc/article/view/2473> Acesso em: 05/10/2020.

RODRIGUES, Marcelo Abelha. Direito ambiental esquematizado. 3. ed. - São Paulo: Saraiva, 2016. 1. Direito ambiental - Brasil I. Título

SALHEB, Gleidson José Monteiro et e al. Políticas Públicas e Meio Ambiente: Reflexões Preliminares. Amapá, n. 01, 2009. Disponível em: $<$ https://periodicos.unifap.br/index.php/planeta/article/view/57/0> Acesso em: 02 de out. de 2020.

SALVADOR. Decreto $\mathbf{n}^{\mathbf{0}}$ 29.100, de 06 de novembro de 2017. Regulamenta o art. $5^{\circ}$ da Lei $n^{\circ}$ 8.474, de 02 de outubro de 2013, e institui o Programa de Certificação 
Sustentável "IPTU VERDE” em edificações no Município de Salvador, que estabelece benefícios fiscais aos participantes do programa, assim como o art. $5^{\circ}$ da Lei 8.723 de 22 de dezembro de 2014 e dá outras providências. Salvador: Câmara Municipal. 2017, disponível em: <http://iptuverde.salvador.ba.gov.br/downloads/Decreto.pdf >Acesso em:09/11/2020.

SIRVINSKAS, Luís Paulo. Manual de direito ambiental. 16. ed. - São Paulo: Saraiva Educação, 2018. 1.

SOUZA, Celina. Políticas Públicas: uma revisão da literatura. Sociologias, Porto Alegre, ano 8, nº 16, jul/dez 2006, p. 20-45.

TRENNEPOHL, Terence. Manual de direito ambiental . 7. ed. - São Paulo: Saraiva Educação, 2019. 


\section{$\mathbf{X}$ \\ O IPTU VERDE DE SALVADOR NA GESTÃO DE RESÍDUOS SÓLIDOS}

Anna Clara Abbehusen ${ }^{34}$

Mariana Alves de Jesus ${ }^{35}$

\section{INTRODUÇÃO}

O presente trabalho nasce da importância temática dos resíduos sólidos enquanto principal problemática urbana vinculada ao uso dos imóveis. A gestão destes resíduos é desafiadora em todo o âmbito nacional, e em Salvador enquanto quarta cidade mais populosa do país. (IGBE, 2018)

A análise do Decreto que institui o IPTU Verde se revela fundamental para a compreensão de sua influência na gestão dos resíduos, a potencialidade do seu impacto assim como a efetividade de sua sustentabilidade, uma vez que se pretende através do instrumento normativo incentivar o comportamento do contribuinte.

A pesquisa é de natureza qualitativa, visitando documentos legislativos e doutrinários não só do Direito como também das Ciências Comportamentais. Este estudo pretende elucidar os obstáculos para implementação de uma política efetivamente ampla e sustentável no que tange a gestão dos resíduos sólidos, além de propor alternativas de aprimoramento do instrumento legislativo.

\section{FUNÇÃO SOCIOAMBIENTAL DO IMÓVEL}

É fundamental entender que a primeira vez em que o Direito demonstrou oficialmente a preocupação do mundo com a relação entre o meio ambiente e o homem, foi na Declaração de Estocolmo de 1972. Ela ocorreu na $1^{\text {a }}$ Conferência Mundial do Meio Ambiente e apresentou medidas protetivas que visavam uma boa interação entre o social e o ambiental, visto que eles são interdependentes, de modo que não há como se

34 Graduanda em Direito (Faculdade Baiana de Direito). Integrante do grupo de pesquisa Direito Ambiental e Resíduos Sólidos em uma perspectiva local e internacional (LAEJU).

${ }^{35}$ Graduanda em Direito (Faculdade Baiana de Direito). Integrante do grupo de pesquisa Direito Ambiental e Resíduos Sólidos em uma perspectiva local e internacional (LAEJU). 
falar em um espaço urbano que forneça uma boa qualidade de vida para os cidadãos, sem que se trabalhe a questão ambiental dentro das cidades.

O Relatório de Brundtland apresentado nesta conferência foi pioneiro na conceituação de sustentabilidade, e assim a definiu:

O desenvolvimento que satisfaz as necessidades presentes, sem comprometer a capacidade das gerações futuras de suprir suas próprias necessidades.

É então a partir deste conceito que se desenvolvem a análise das medidas propostas pelo Decreto. A função social do imóvel, que permeia a fundamentação do IPTU Verde, é a destinação da propriedade no que tange o interesse e proveito coletivo, da sociedade como um todo (FARIAS, ROSENVALD, 2018, p.512). A desvirtuação desta função social quando extrema, é, inclusive, passível de desapropriação. No âmbito rural, a função social do imóvel normalmente está relacionada à sua produtividade agropecuária e à sua preservação do meio ambiente natural, influenciando diretamente no cálculo tributário do ITR, o imposto territorial rural. No urbano, entretanto, a função social é extremamente ampla e diversa.

O imóvel do meio urbano possui um espectro de destinação econômica e social muito mais amplo que o rural, abrangendo comércio, indústria, residência e serviços. Cada destinação específica possui suas peculiaridades quanto à capacidade lesiva ao meio ambiente: as indústrias por exemplo, são potencialmente mais lesivas aos recursos hídricos e à atmosfera, enquanto o comércio e as residências são potenciais poluentes pela incorreta destinação de resíduos sólidos. Os terrenos, por sua vez, são potenciais depósitos de resíduos urbanos e foco de pragas urbanas (DANTAS, 2014, p. 39 e 40).

Desse modo, a formação de cidades sustentáveis ocorre através da função socioambiental da propriedade urbana, visto que existe a obrigação de que o direito de propriedade seja exercido em conformidade com as leis ambientais (DANTAS, 2014, p. 40). Assim, é de extrema importância que se promova o respeito às cadeias ecossistêmicas quando se pensa em desenvolvimento urbano, promovendo então, uma maior qualidade de vida nas cidades e o bem-estar coletivo.

Ainda assim, independente da potencial lesividade, não se pode perder de vista a função socioambiental do imóvel, que pode ser extraída do mandamento constitucional:

Art. 225. Todos têm direito ao meio ambiente ecologicamente equilibrado, bem de uso comum do povo e essencial à sadia 
qualidade de vida, impondo-se ao Poder Público e à coletividade o dever de defendê-lo e preservá- lo para as presentes e futuras gerações.

Neste artigo se enfatiza o meio ambiente enquanto direito fundamental assim como a responsabilidade compartilhada de sua proteção. De forma mais específica, é também contemplado no Código Civil:

Art. 1228 § 1 O direito de propriedade deve ser exercido em consonância com as suas finalidades econômicas e sociais e de modo que sejam preservados, de conformidade com o estabelecido em lei especial, a flora, a fauna, as belezas naturais, o equilíbrio ecológico e o patrimônio histórico e artístico, bem como evitada a poluição do ar e das águas.

Embora não seja neste artigo mencionada a poluição do solo, ainda que a interpretação não deva ser literal, é notória a potencialidade de poluição atmosférica e hídrica de forma indireta pelos resíduos, decorrente da destinação imprópria.

O desafio é identificar e implementar uma política eficiente de reforço da sua utilização sustentável ou mesmo redutora de danos. Neste sentido nasce o IPTU Verde, aqui analisado apenas na cidade de Salvador-BA, mas implementado em inúmeros municípios do país.

No que tange o potencial poluidor, destacamos a gestão de resíduos sólidos como principal problemática urbana vinculada ao uso dos imóveis e será analisada através dos recortes de sua destinação. Segundo o inventário de emissões de gases estufa realizado de 2014 a 2018 em Salvador, a emissão do setor de resíduos é em média $10,84 \%$ do total de emissões. Além disso, em nível nacional, estima-se que cerca de $40 \%$ dos resíduos não têm destinação adequada, quando dispostos em lixões a céu aberto ou aterros controlados, segundo publicação da Abrelpe em 2019.

Os 17 Objetivos do Desenvolvimento Sustentável (ODS) são metas estabelecidas pela ONU a serem cumpridas através de uma ação global, para que se atinja a Agenda 30. Eles têm finalidades como acabar com a pobreza, a redução das desigualdades, energia limpa e acessível, entre outros. Dentre esses objetivos, o ODS 13 promove a ação contra a mudança global do clima, visando a adoção de medidas urgentes para a mitigação das mudanças climáticas e dos seus impactos. Uma das metas dentro desse ODS é justamente a implementação de políticas e planejamentos nacionais que visem o combate a essas alterações, e o IPTU VERDE pode ser visto como uma ótima estratégia para se atingir esses objetivos (ONU, 2015). 
Ao reconhecer que a propriedade tem uma função social, entende-se que o gozo desse direito não legitima a emissão de poluentes gerados por este e que irá invadir a propriedade de outros indivíduos, e assim, é possível entender que a propriedade vai além do social, adentrando também nas relações ambientais. Assim, a propriedade urbana e os imóveis devem respeitar o princípio da função social da propriedade, visando cumprir com seus objetivos econômicos, ambientais e sociais.

O inciso XXIII do artigo 5 e no 182 da Constituição Federal de 1988 expressam a necessidade e importância da propriedade cumprir sua função socioambiental urbana, enquanto o Estatuto das Cidades determina medidas para uma gestão do solo urbano de forma mais correta, traçando objetivos e características para os imóveis, que evidenciam ainda mais os fatores ambientais e sociais que devem estar presentes nos planos do Município (DANTAS, 2014, p. 39-42).

\section{EXTRAFISCALIDADE E REFORÇO COMPORTAMENTAL}

A extrafiscalidade pode ser compreendida como uma função exercida pelos tributos, onde o objetivo é estimular ou desencorajar determinados comportamentos da população. O tributo, portanto, vai além da função meramente arrecadatória e pretende influenciar o alcance de determinadas finalidades, como pontifica a Ministra Regina Helena Costa, 2018, p. 182:

A extrafiscalidade, por sua vez, consiste no emprego de instrumentos tributários para o atingimento de finalidades incentivadoras ou inibitórias de comportamentos, com vista à realização de outros valores, constitucionalmente contemplados.

Desse modo, o Estado costuma incentivar ou desencorajar a população a realizar ações que compactuam com o que o Poder Público considera ser certo e errado. E visto que aa questões ambientais e climáticas têm sido cada vez mais debatidas nacionalmente e internacionalmente, ela se apresentam como uma pautas muito importantes e que precisam ser trabalhadas nas ações do dia a dia dos cidadãos.

A lei que institui o IPTU, Lei 8474/2013, na cidade de Salvador prevê em seu $\operatorname{artigo} 5^{\circ}$ :

O Poder Executivo poderá conceder desconto de até 10\% (dez por cento) do Imposto Predial e Territorial Urbano (IPTU) a proprietários de imóveis residenciais e não residenciais no município de Salvador que adotem medidas que estimulem a proteção, preservação e 
recuperação do meio-ambiente, na forma e condições estabelecidas em regulamento.

Este dispositivo consagra a função extrafiscal do tributo, que se propõe a reforçar através do desconto no imposto o comportamento sustentável do contribuinte. A efetividade e potencialidade do incentivo, entretanto, são analisadas sob a ótica Behaviorista do conceito de reforço, que consiste no aumento de probabilidade da resposta esperada em função de certo estímulo (SKINNER, 2006, p.44).

Significa, portanto, que apenas a existência de uma legislação não é suficiente para a efetivação do seu propósito, devendo ser considerados também os fatores de estímulo e o contexto em que estão inseridos.

\section{O IPTU VERDE NA GESTÃO DOS RESÍDUOS SÓLIDOS}

O termo green tax é utilizado pelos economistas ao falarem sobre os mecanismos do tributo dentro da implementação das medidas protetivas do direito ambiental e de suas políticas (CARNEIRO, 2003. p.78). Ao versar sobre esse termo, por consequência, também estará se falando sobre as espécies tributárias que possuem uma finalidade ambiental, um objetivo verde.

O decreto $\mathrm{N}^{\circ} 29.100$, de 06 de novembro de 2017 regulamenta o Art. $5^{\circ}$ da lei $\mathrm{n}^{\circ}$ 8.474, de 02 de outubro de 2013, e institui o Programa de Certificação Sustentável "IPTU VERDE". O programa é destinado a incentivar a conduta sustentável do proprietário/possuidor através do benefício fiscal de desconto no IPTU.

O maior desconto é o referente aos terrenos não edificáveis que se encontram em Áreas de Preservação Ambiental (APA's), que, enquanto unidades de conservação, apresentam $80 \%$ de desconto sobre a área não edificável. Este é o maior incentivo fiscal do decreto e se revela fundamental no meio urbano, uma vez que a preservação vegetal é vista como obstáculo na exploração econômica, embora de fundamental importância para a redução de danos das mudança climáticas.

O outro desconto é escalado em três categorias, que variam com a quantidade e qualidade dos atributos sustentáveis das edificações, e variam entre 5, 7 e $10 \%$ de desconto.

É acertadamente destinado a imóveis tanto residenciais quanto comerciais, uma vez que ambos podem e devem implementar, na medida de suas possibilidades, práticas 
sustentáveis (JACOBI; BENSEN, 2011). Entretanto, o tratamento indistinto e genérico em face das flagrantes peculiaridades decorrentes das destinações dos imóveis representa uma redução de efetividade daquilo que se propõe. Por exemplo, enquanto os imóveis comerciais produzem resíduos sólidos em maior quantidade, estes são em maioria recicláveis enquanto o resíduo doméstico embora em menor quantidade seja composto em maior parte por resíduo orgânico: o direcionamento de políticas específicas frente a tais particularidades é potencialmente reforçador.

O incentivo em si, por maior que seja o valor do IPTU pago, é ínfimo comparado ao investimento necessário para implementação da mais simples estrutura para receber o menor desconto, sobretudo em curto prazo. O conceito Behaviorista de reforço de comportamento compreende o aumento de probabilidade de determinada resposta em face de um estímulo (SKINNER, 2006, p.51). Neste caso, o custo da resposta é maior do que o incentivo da consequência programada e, portanto, não se enquadra como reforço de alta potência, e desvirtua a própria função extrafiscal do tributo. Diferente, por exemplo, do investimento em energia solar, que embora tenha um preço elevado é atrativo pela economia imediata alheia ao incentivo estatal.

Existe a internalização dos custos socioambientais dentro do tributo, visto que os recursos naturais são finitos e as necessidades humanas são crescentes, sendo necessária a internalização desses custos dentro da equação tributária, na tentativa de promover o desenvolvimento sustentável. Desse modo, a tributação ambiental pode promover uma absorção dos custos referentes aos danos ambientais causados pelos produtos e serviços, permitindo que os valores sejam proporcionais à utilização dos recursos naturais utilizados e da degradação provocada, refletindo a geração dos resíduos sólidos, do consumo e do seu descarte (DANTAS, 2014, p. 51 e 52).

A valoração dos próprios atributos sustentáveis revela uma inclinação de incentivo maior aos sistemas de gestão das águas, como aproveitamento de água pluvial e reaproveitamento de águas cinzas, além de instrumentos redutores de desperdício hídrico. De igual forma, é altamente valorado o sistema de autonomia energética e redução do consumo energético.

O setor mais desvalorizado é curiosamente o de resíduos sólidos: ainda que implementados todos os requisitos, estes somam apenas 14 pontos dos 50 necessários para obter o menor desconto. Os próprios requisitos não são necessariamente sustentáveis, uma vez que, em sua maioria, implicam apenas na questão logística de materiais e não em sua redução e/ou reaproveitamento. 
Um destes atributos merece uma análise especial em razão da possível transferência de competência e além de se questionar a sustentabilidade desta prática. $\mathrm{O}$ item 59 do anexo do decreto inclui a instalação de trituradores de pia em mais de $90 \%$ dos pontos: os trituradores são instalados no encanamento da pia da cozinha, e através de eletricidade trituram a matéria orgânica ali inserida. Depois de triturada, a matéria segue pela tubulação de esgoto da mesma forma que a água. Imagina-se que a destinação principal deste uso seja doméstico e não industrial.

O primeiro ponto relevante sobre o uso deste equipamento é sobre seu duvidoso caráter sustentável. De fato, a matéria orgânica, dentro dos resíduos sólidos, é de difícil gestão e altamente poluente em função da decomposição em gás metano. O desvio dessa matéria para estação de tratamento de esgoto, principalmente sem um prévio estudo técnico sobre a capacidade de absorção, pode implicar em sérias obstruções e comprometimento do sistema de esgoto, que inclusive atende 92,8\% da capital, além do decorrente risco de contaminação dos corpos hídricos (IBGE, 2020). O próprio equipamento não tem valor acessível a todas as camadas sociais e dificilmente será implementado pelos cidadãos de forma geral.

A outra questão a ser levantada é sobre a transferência de competência de gestão sobre este resíduo: Embora a competência sobre o saneamento básico seja compartilhada entre os entes federados, na prática o que ocorre é a concentração desta competência no estado através da Embasa, empresa de economia mista, tendo o Estado da Bahia como maior acionista. Significa dizer que, diminuem-se os encargos no município em função da redução de demanda sobre resíduos sólidos, e aumentam-se as despesas no tratamento de efluentes por parte do estado.

É de se estranhar que logo o setor que trata de competência direta do município, seja o menos valorizado: A implementação de práticas sustentáveis quanto aos resíduos sólidos impactaria positivamente na própria redução de despesa com coleta e disposição em função da redução.

Neste sentido, no que tange os resíduos orgânicos e sua destinação, é mais sustentável e acessível a adoção de composteiras domésticas. Embora demandem manejo e algum conhecimento técnico, são potenciais redutores de resíduos orgânicos, além de altamente acessíveis. A inclusão ou substituição deste item no rol de ações e instrumentos sustentáveis do decreto aparenta ser mais reforçadora e democrática, principalmente se valorada como os itens de energia e recursos hídricos (MINISTÉRIO DO MEIO AMBIENTE, 2017). 


\section{CONSIDERAÇÕES FINAIS}

O Programa de Certificação Sustentável instituído pelo Município de Salvador demonstra ser insuficiente enquanto política pública de incentivo à utilização sustentável da propriedade urbana. O obstáculo do programa reside no alto custo de implementação dos requisitos mínimos necessários e no baixo incentivo fiscal enquanto contrapartida.

No que tange a efetividade do programa em relação a gestão de resíduos sólidos é notória a descredibilidade do setor quando quantificada sua pontuação: Ainda que adotados todos os requisitos, estes sequer alcançam a pontuação mínima que ensejam o menor desconto, diferente dos setores de energia alternativa e recursos hídricos. Representa, portanto, uma subutilização do instrumento que impacta diretamente na competência do município e seu orçamento.

Ainda sobre os resíduos sólidos, os próprios requisitos de implementação do setor tem sua sustentabilidade questionada: A maioria dos itens implicam na logística dos resíduos do que na sua efetiva redução, reutilização ou reciclagem. De igual forma, o tratamento genérico entre os contribuintes despotencializa o melhor aproveitamento desta política.

Diante da análise do referido Decreto, se propõe como medida de aprimoramento o aumento do incentivo fiscal aliado à inclusão de requisitos economicamente mais acessíveis e igualmente sustentáveis. Tal iniciativa poderá de fato incentivar a adesão ao programa além de democratizá-lo.

É também imprescindível um estudo de gravimetria do lixo urbano em Salvador, que poderá elucidar melhor as peculiaridades da produção de lixo no município, e a partir disso, fundamentar políticas direcionadas e mais funcionais.

\section{REFERÊNCIAS}

BRASIL, Constituição da República Federativa do Brasil. Disponível em: <http://www.planalto.gov.br/ccivil_03/constituicao/constituicao.htm>. Acesso em: 20 jun. 2020.

, IBGE. Censo Demográfico, 2020. Disponível em:

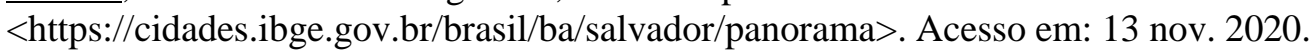


Lei 6.938, de 31 de Agosto de 1981. Dispõe sobre a Política Nacional do Meio Ambiente, seus fins e mecanismos de formulação e aplicação e dá outras providências.Brasília, DF, 31 ago. 1981. Disponível em: <http://www.planalto.gov.br/ccivil_03/LEIS/L6938.htm>. Acesso em 20 jun. 2020.

, Lei 10.406, de 10 de Janeiro de 2002.Institui o Código Civil. Brasília, 10 jan. 2002. Disponível em: <http://www.planalto.gov.br/ccivil_03/leis/2002/110406.htm>. Acesso em 20 jan. 2020.

BRAGA NETTO, Felipe Peixoto; FARIAS, Cristiano Chaves; ROSENVALD, Nelson. Curso de Direito Civil: Direito das Coisas. Salvador: Juspodivm, 2019.

DANTAS, Tourinho Gisane. O IPTU Verde como Instrumento de Efetividade da Função Socioambiental da Propriedade Privada Urbana. 2014. Dissertação (Mestrado em Direito) Universidade Federal da Bahia, Salvador/BA, 2014.

Decreto $n^{\circ}$ 29.100. 06 de novembro de 2017.(2017). Institui o Programa de Certificação Sustentável "IPTU VERDE". Disponível em:

<http://iptuverde.salvador.ba.gov.br/downloads/Decreto.pdf>.Acesso em: 23 out. 2020.

FIORILLO, Celso Antonio Pacheco.Curso de Direito Ambiental Brasileiro. 19. ed. São Paulo: Saraiva Educação, 2019.

JACOBI, Pedro Roberto; BESEN, Gina Rizpah. Gestão de resíduos sólidos em São Paulo: desafios da sustentabilidade. Estud. av, São Paulo, ano 2011, v. 25, ed. 71, jan./Abr. 2011. Disponível em: <http://www.scielo.br/scielo.php?script=sci_arttext\&pid=S010340142011000100010>. Acesso em: 1 nov. 2020.

MMA - MINISTÉRIO DO MEIO AMBIENTE. Compostagem Doméstica, Comunitária e Institucional de Resíduos Orgânicos. Manual de Orientação. Brasília, 2017.

SKINNER, Burrhus Frederic. Sobre o Behaviorismo.10 ed. São Paulo: Cultrix, 2006.

ORGANIZAÇÃO DAS NAÇÕES UNIDAS (ONU). Objetivo do Desenvolvimento Sustentável 13. In: Ação contra mudança global do clima. Disponível em: <https://brasil.un.org/ptbr/sdgs/13>. Acesso em: 1 nov. 2020. 


\section{XI \\ DIREITO À CIDADE SUSTENTÁ VEL EM UMA SOCIEDADE LIXO ZERO}

Suzana Lopes Conceição ${ }^{36}$

Todo cidadão tem direito à cidade, direito humano e coletivo. Nesse sentido é fundamental ter um compromisso ético e político de defesa de um bem comum essencial a uma vida plena e digna. $\mathrm{O}$ direito à cidade foi abordado pela primeira vez pelo filósofo francês Henri Lefebvre em 1968, com a publicação de sua obra Le Droit à La Ville, na qual o autor aborda as reivindicações sobre liberdades civis e respeito aos direitos humanos, além dos antagonismos presentes nas cidades de todo o mundo ocidental.

Segundo o autor Lefebvre (2010), direito à cidade é um conjunto de ideias que traduzem uma demanda por um acesso ao qual renova e transforma a vida urbana. $\mathrm{O}$ autor também abordou a produção das cidades que valorizam o valor de uso do espaço urbano, sobretudo, ao direito de experimentar e usufruir da centralidade urbana no ritmo do valor de uso em oposição ao valor de troca, o que exige necessariamente o rompimento com a lógica capitalista de produção do espaço.

Entretanto, para uma cidade produzir é necessário que ela esteja engajada nas bases da sustentabilidade, interagindo com o mundo, preservando o meio ambiente para não comprometer os recursos naturais. A sustentabilidade surgiu a partir de uma reunião que aconteceu na Suíça, na cidade de Estocolmo, em 1972, na qual foi elaborada a Declaração de Estocolmo chamada de Plano de Ação, que define a preservação e melhoria do meio ambiente para as futuras e atuais gerações.

Observa-se que, o Projeto do Plano de Ação da Sustentabilidade, foi elaborado juntamente com a Paz e o Desenvolvimento Econômico e Social. Nesse sentido, esse projeto abordou o princípio da Sustentabilidade, tendo como foco os seres humanos e a proteção do meio ambiente como partes fundamentais desse processo. Pois, o uso dos

\footnotetext{
${ }^{36}$ Graduanda em Direito pela Universidade Católica do Salvador (UCSal).Integrante do grupo de pesquisa Direito Ambiental e Resíduos Sólidos em uma perspectiva local e internacional (LAEJU). Email:ssuzanlopes@gmail.com
} 
recursos naturais presentes, não podem comprometer as necessidades das próximas gerações. Assim sendo, é preciso que todos os recursos utilizados sejam através de atitudes ecologicamente corretas.

Ademais, o termo sustentabilidade vem sendo discutido desde 1972, o qual é um dos pilares de uma cidade sustentável. Porém, para se ter uma sociedade lixo zero, é preciso uma mudança no comportamento diário das pessoas, dos administradores das empresas, sendo necessário mudar a cultura. Contudo, mudança cultural é algo difícil e requer ações de impacto.

Atualmente, o mundo vive uma crise na gestão e gerenciamento dos resíduos sólidos, principalmente no cenário brasileiro. Segundo a então atual senhora Maimunah Mohd Sharif a qual ocupa o cargo de diretora executiva do Programa das Nações Unidas para Assentamentos Humanos (ONU-Habitat), por ano são produzidos mais de dois bilhões de toneladas de resíduos em todo mundo.

Nessa mesma ótica, o Boletim de Análise de Conjuntura em Relações Internacionais enfatiza que os resíduos sólidos têm crescido em taxas exponenciais. Isto é uma das resultantes de padrões insustentáveis de produção e consumo. Constituindo assim, um problema global tanto na perspectiva da economia política internacional, quanto da governança ambiental local e global.

Dessa forma a pesquisa primeiramente abordará os conceitos históricos sobre o Direito à cidade e sua relação com o direito humano, expondo os principais pontos desse direito para o cidadão, como espaços que agreguem às pessoas, garantam moradias adequadas, acessos aos serviços básicos dentre outros. Em seguida será analisada a relação entre o direito à cidade e sua sustentabilidade, com estudo sobre como uma cidade pode se tornar sustentável, enfatizando os 17 Objetivos de Desenvolvimento Sustentável e como as cidades brasileiras estão enquadradas nesse desenvolvimento de forma ambiental enfatizando o seu tratamento com os resíduos sólidos. Na terceira e última parte será abordado como a cidade do Salvador adotando as políticas de meio ambiente e como está destinando os seus resíduos sólidos para se tornar uma sociedade lixo zero. Partindo desse contexto, pretendemos concluir se é possível se chegar a uma cidade com lixo zero e sustentável. 


\section{DIREITO À CIDADE}

As cidades devem ser lugares coletivos, onde desigualdades precisam ser combatidas. Entretanto, o que pode ser notado vai de encontro a realização dos direitos, aprofundando a desigualdade. Esse crescimento acelerado e sem planejamento tem provocado uma produção grande de resíduos sólidos, o qual vem criando riscos a manutenção da sustentabilidade.

Segundo Lefebvre, no passado existiam cidades do tipo oriental, cidades arcaicas, e depois as cidade medievais, sendo que os dois primeiros modelos eram essencialmente políticos. Por sua vez, a cidade medieval, não perdeu o caráter político, mas foi principalmente comercial, artesanal, bancária. Ela integrou os mercadores outrora quase nômades, relegados para fora da cidade. A cidade não é algo novo, pois desde o período clássico ela já exercia um papel de centralidade, contudo o termo urbano surge somente a partir da sua industrialização.

Sendo assim, o termo urbano decorre do processo de intensificação da industrialização, a qual proporcionou um crescimento exponencial da cidade e a sua agregação de valor de uso.

A cidade e a realidade urbana dependem do valor de uso. $\mathrm{O}$ valor de troca é a generalização da mercadoria pela industrialização tendem a destruir, ao subordiná-las a si, a cidade e a realidade urbana, refúgios do valor de uso, embriões de uma virtual predominância e de uma revalorização do uso. (LEFEBVRE, 2010, p.14).

Convém ressaltar, conforme descrito no repositório do Instituto de Pesquisa Econômica Aplicada (IPEA), o direito à cidade está descrito no Estatuto da Cidade (Lei $\mathrm{n}^{\mathrm{o}} 10.257 / 2001$ ), no art. $2^{\circ}$, incisos I e II, que dispõem sobre o direito a cidades sustentáveis. Esse estatuto regulamenta os artigos referentes à política urbana no âmbito federal, conforme os artigos 182 e 183 da Constituição Federal de 1988 (CF/1988). Assim, pode-se dizer, então, que a ideia de direito à cidade expressa na lei sintetiza um amplo rol de direitos. No Estatuto da Cidade, o direito às cidades sustentáveis é compreendido como "o direito à terra urbana, à moradia, ao saneamento ambiental, à infraestrutura urbana, ao transporte, aos serviços públicos, ao trabalho e ao lazer, para as presentes e futuras gerações" (art. $2^{\circ}$, inciso I da Lei $\left.n^{\circ} 10.257 / 2001\right)$. Portanto, a ideia de direito à cidade expressa na lei sintetiza um amplo rol de direitos. 
Contudo, o direito à cidade trata-se de uma liberdade individual de acesso aos recursos urbanos. Conforme sintetizado nas palavras de David Harvey artigo publicado na revista New Left Review (2008), a cidade é o direito de lutar pela mudança da cidade. Além disso, trata-se de um direito coletivo, não individual, um direito difuso, de natureza indivisível, já que, essa transformação depende do exercício de um poder coletivo para remodelar os processos de urbanização. Portanto, o direito à cidade depende inevitavelmente ao exercício de um poder coletivo para reformular os processos de produção do espaço, pois em cada sociedade faz emergir questões próprias a serem enfrentadas.

Observa-se, então, que metade da população vive na área urbana, esse crescimento desordenado sem planejamento causa várias consequências nas cidades, pois, essas são desprovidas de infraestruturas e de benefícios sociais, causando uma degradação do meio ambiente. Nesse sentido, faz-se necessários que as pessoas tenham um planejamento, uma boa gestão, consciência política, economia responsável, compromisso com os valores sociais e cuidado com o meio ambiente, pois os recursos naturais são escassos, principalmente em uma sociedade em crescimento sem as bases de sustentabilidade.

Conforme exposto por Saches (1993, p.103) a sustentabilidade constitui-se num conceito dinâmico, que leva em conta as necessidades crescentes das populações, num contexto internacional em constante expansão. Porém, a ONU sintetiza o desenvolvimento sustentável como o atendimento às necessidades do presente, sem comprometer a possibilidade das gerações futuras atenderem suas próprias necessidades.

A partir das conferências promovidas pela ONU em Estocolmo (1972) e no Rio (1992), foi debatido que o desenvolvimento sustentável deve incluir a questão social, promovendo e garantido a qualidade de vida das gerações atuais e futuras. Essas estratégias são para moldar ações com o objetivo de proteger o meio ambiente. Segundo a Fundação Instituto de Administração, essas confederações foi o momento que a comunidade política internacional admitiu claramente que era preciso conciliar o desenvolvimento socioeconômico com a utilização dos recursos da natureza, agregando os componentes econômicos, ambientais e sociais.

Em suma, para que uma cidade se torne sustentável, esta tem que prevê várias diretrizes capazes de promover uma boa gestão, consciência política, economia 
responsável, compromisso com os valores humanos. Porém, para que seja adotada essas diretrizes os países tiveram que adotar a nova política global: a chamada de Agenda 2030 para o Desenvolvimento Sustentável. Essa Agenda 2030 busca fortalecer a paz universal através de um plano de ação para as pessoas, o planeta e a prosperidade.

Segundo o Instituto Puruna, o desenvolvimento sustentável tem como objetivo erguer o desenvolvimento do mundo para uma melhor qualidade de vida de todas as pessoas, porém, para isso foi necessário elencar os 17 Objetivos de Desenvolvimento Sustentável (ODS) com 169 metas; metas essas que para serem alcançadas se faz essencial uma ação conjunta que agrega diferentes níveis de governo, organizações, empresas e a sociedade como um todo nos âmbitos internacional, nacional e local.

Desse modo, nas palavras do então secretário-geral da ONU, Ban Ki-Moon, no discurso de abertura da Cúpula das Nações Unidas sobre Desenvolvimento Sustentável, enfatiza que a nova agenda é uma promessa dos líderes para a sociedade mundial. É uma agenda para acabar com a pobreza em todas as suas formas, uma agenda para o planeta. Porém, um dos grandes problemas a serem resolvidos pelos municípios são as responsabilidades do manejo dos resíduos sólidos urbanos. Isso ocorre devido ao descarte inapropriado de resíduos com potencial danoso ao meio ambiente.

Cabe ressalvar, que a produção de resíduos sólidos vem crescendo em todas as regiões do Brasil, conforme expõe o autor GOUVEIA (2012, p.2) e parte considerável desses resíduos não possui destinação sanitária correta. $\mathrm{O}$ autor afirma também, que mesmo tenha existido um avanço nos últimos anos o que permite a utilização por parte dos entes municipais de aterros controlados; ainda existe elevado quantitativo de áreas que servem de depósito: os lixões. Por tais razões, é necessária a aplicação de medidas para mudanças do comportamento da sociedade diante de questões dessa natureza.

Assim sendo, faz-se necessário que as ações realizadas pelos municípios devem estar em consonância com os objetivos traçados pela Agenda 2030 da ONU através de políticas públicas. Pois, uma má gestão dos resíduos sólidos causam uma série de impactos ambientais e danos à saúde humana.

Para BARBORSA e IBRAHIN, (2014, p.16), os danos ambientais ocorrem muitas vezes por falta de informação, por negligência ou pela falta de uma gestão pública adequada de saneamento básico, pois, o destino do lixo nem sempre foi motivo de preocupação para a sociedade, e, mesmo com o surgimento de políticas ambientais e outras normas que regulamenta o descarte e o controle dos materiais poluentes, os avanços ainda são tímidos na gestão dos excedentes residuais. 
Porém, é um desafio que a sociedade deve buscar adequar-se em todos os setores, pois "todo o resíduo gerado por cada ser humano deveria retornar à cadeia produtiva para compor matéria-prima orgânica ou a geração de novos produtos para a indústria" (LUZ, 2019, p.105). Neste mesmo contexto a autora enfatiza que se faz necessário o processo de logística reversa proposta pela lei de resíduos sólidos, cada resíduo conta, pois é sempre menos um lixo descartado.

No Brasil temos algumas cidades que apresentam uma destinação adequada para os seus resíduos sólidos e rejeitos. Seguindo assim, os requisitos amparados pela Lei 12.305/2010, a qual institui a Política Nacional dos Resíduos Sólidos (PNRS) tem como objetivo a organização e forma com que o país estrutura o seu lixo em todos os setores tanto no setor público como no privado. Essa lei tem 15 objetivos, tendo como destaque a redução de resíduos e fim dos Lixões.

Segundo o Ministério do Meio Ambiente, essa lei contém instrumentos importantes que permitem o avanço necessário do País no enfrentamento dos principais problemas ambientais, sociais e econômicos decorrentes do manejo inadequado dos resíduos sólidos. Prevê também, a prevenção e a redução na geração de resíduos, tendo como proposta a prática de hábitos de consumo sustentável e um conjunto de instrumentos para propiciar o aumento da reciclagem e da reutilização dos resíduos sólidos além da destinação ambientalmente adequada dos rejeitos.

Temos como exemplo à cidade de Florianópolis, a primeira cidade brasileira a aderir ao programa lixo-zero. De acordo com as palavras de Carolina Marasco, matéria divulgada no site NSC Total, a cidade de Florianópolis em 2015 criou o Plano de Ação Florianópolis Sustentável, que tem como um dos requisitos a gestão dos resíduos sólidos. Através de um decreto da prefeitura municipal, a cidade pretende chegar a ser $100 \%$ sustentável. Portanto, essa ação prevê a redução em gastos com aterro sanitário e a destinação correta dos resíduos. O decreto ainda tem como meta a redução de envio de lixo seco e de lixo orgânico para os aterros sanitários da região.

Por outro lado, ao analisar os resíduos sólidos da cidade do Salvador, esta dispõe de uma Gestão Integrada dos Resíduos Sólidos, que foi implementada antes mesmo da PNRS, a qual tem como uns dos principais objetivos a coleta seletiva, mas para que possa atingir as metas dessa Política com destinação adequada dos rejeitos, é preciso que todas as metas e objetivos sejam aplicados e seguidos por todos. Contudo, as 
cidades ainda não conseguem absorver a quantidade crescente de resíduos sólidos urbanos.

A Gestão Integrada de Resíduos Sólidos do município do Salvador não consegue atingir as suas metas, mesmo com a criação de entidades regulamentadoras e fiscalizadoras da gestão municipal dos resíduos. Isso decorre por conta dos diversos segmentos do poder público, pois eles não possuem uma comunicação interligada. As ações criadas entre as entidades tanto no âmbito municipal como no estadual devem estar interligadas para sua eficácia. Pois, a gestão de resíduos sólidos para ser eficiente tem que envolver todas as esferas.

Porém, mesmo com os diversos problemas de gestão e comunicação entre as entidades, a prefeitura do Salvador, em 2017, criou o sexto eixo do programa Salvador 360 - Cidade Sustentável desenvolvimento econômico e social dos cidadãos, com destaque nas áreas de meio ambiente, sustentabilidade e resiliência, segundo o site da Prefeitura de Salvador, esse programa tem 02(dois) objetivos: um de sustentabilidade e outro de resiliência. Além disso, foram criados diversos programas que garantem uma cidade sustentável, como por exemplo o IPTU Verde, programa esse destinado a incentivar empreendimentos imobiliários residenciais, comerciais, mistos ou institucionais a realizarem e contemplarem ações e práticas de sustentabilidade em suas construções, conforme decreto ${ }^{\circ} 25.899$ de 24 de março de 2015.

Já no âmbito estadual a cidade do Salvador, tem a Política Estadual de Resíduos Sólidos (PERS/BA), instituída por meio da Lei Estadual n 12.932, de 07 de janeiro de 2014, que tem como principal objetivo estabelecer normas relativas à gestão e ao gerenciamento integrados de resíduos sólidos, em regime de cooperação com o setor público, o setor empresarial e os demais segmentos da sociedade civil. Conforme site LegisWed essa lei integra a Política Estadual de Meio Ambiente e de Proteção à Biodiversidade, instituída pela Lei $\mathrm{n}^{\circ} 10.431$, de 20 de dezembro de 2006, e a Política Estadual de Saneamento Básico, instituída pela Lei $\mathrm{n}^{\mathrm{o}} 11.172$, de 01 de dezembro de 2008 .

Portanto, para que a cidade do Salvador tenha uma destinação correta dos seus resíduos sólidos, faz-se necessário que a sociedade aplique mudanças comportamentais nos hábitos das pessoas. Pois, muitos resíduos são descartados em locais inadequados causando danos ambientais, muitas vezes irreversíveis. É preciso que as ações de sustentabilidade sejam incorporadas em serviços fundamentais, como nas escolas, universidades, comunidades, sociedades civis, empresas públicas e privadas. Cada 
pessoa deve ter o compromisso com a manutenção da vida e construção de um mundo melhor.

Outro fator importante para se chegar a uma sociedade lixo zero, são os movimentos dos catadores de materiais recicláveis, conforme sintetiza a autora (LUZ,2019, p.106), o resíduo sólido reutilizado e reciclável como um bem econômico e de valor social, gerador de trabalho, renda e também promotor de cidadania. Nas palavras da autora, as atividades exercidas pelos catadores de materiais recicláveis são tratadas pela PNRS como fundamental para o adequado manejo dos resíduos sólidos, pois, eles recolhem materiais reaproveitáveis no processo produtivo, diminuindo assim o uso de novos recursos naturais, contribuindo para a eliminação dos lixões e a proteção do meio ambiente.

Segundo os autores BARBORSA e IBRAHIN (2014, p.17), a problemática do lixo pode ser resolvida por meio do beneficiamento dos resíduos, provenientes de sua correta separação. A PNRS (Lei no 12.305/ 2010), capítulo II, artigo 3o, alínea XVI, define resíduos sólidos como:

\begin{abstract}
[...] material, substância, objeto ou bem descartado resultante de atividades humanas em sociedade, a cuja destinação final se procede, se propõe proceder ou se está obrigado a proceder, nos estados sólido ou semissólido, bem como gases contidos em recipientes e líquidos cujas particularidades tornem inviável o seu lançamento na rede pública de esgotos ou em corpos d'água, ou exijam para isso soluções técnica ou economicamente inviáveis em face da melhor tecnologia disponível.
\end{abstract}

Convém ressalvar, nas palavras dos autores BARBORSA e IBRAHIN, os resíduos devem ser tratados o máximo possível, para o seu reaproveitamento em sua fonte de origem, em outro processo produtivo ou alguma atividade econômica ou social, e que depois de esgotadas todas as possibilidades de beneficiamento, destinar adequadamente os resíduos que serão descartados, contribuindo com a melhoria das estruturas relacionadas com à saúde coletiva e ao meio ambiente.

\title{
CONSIDERAÇÕES FINAIS
}

O direito à cidade é um direito assegurado a todos os cidadãos é a liberdade individual de cada ser humano em ter acesso aos recursos urbanos e naturais. Porém, esse direito deve ser preservado para as futuras gerações, todos têm o direito de usufruir 
do compromisso ético e político que cada ser deve ter para preservar o convívio em uma sociedade mais justa e igualitária.

Assim sendo, esse direito deve ser exercido por todos, sem nenhuma distinção através dos movimentos sociais que estão se fazendo presentes nos dias atuais. A cidade é um bem que todos devem proteger e promover a preservação dos seus recursos naturais que são escassos. Essa preservação não deve ser exclusiva dos entes públicos, mas de toda a sociedade civil. É preciso que todos tenham a consciência que o direito de proteção da cidade é de todos, é um direito assegurado pela Constituição federal.

Desta forma, a preservação dos recursos naturais poderá assegurar que as futuras gerações possam viver em um mundo com desenvolvimento, autonomia e inclusão social. É importante salientar que, a sustentabilidade é a base para se assegurar uma cidade digna para todos, devendo todos contribuírem para o desenvolvimento sustentável. Porém, para que a sustentabilidade seja efetiva nas cidades, foram criadas leis e normas que deverão ser adotadas para que o crescimento tenha bases sustentáveis, amenizando os impactos ambientais.

Cabe ressalvar, que as cidades têm vários problemas socioambientais, e um deles é o descarte desordenado de resíduos sólidos. Mesmo após a instituição da Política Nacional de Resíduos Sólidos (PNRS), muitas cidades ainda mantêm lixões e aterros sanitários sem o tratamento adequado.

Pois, o direito à cidade se refere ao respeito a quem nela vive e as suas futuras gerações, sendo um direito humano e coletivo. Esse direito está ligando ao nosso cotidiano, as nossas atividades diárias, quando contribuímos para o seu crescimento, temos o direito de desfrutá-la de forma justa e equitativa.

No entretanto, existem cidades em que a sustentabilidade é feita de forma adequada com a aplicação das políticas de educação ambiental para que todos promovam a preservação ambiental e o cuido com os resíduos sólidos. Os estados e municípios têm uma função de suma importância para a propagação das políticas de gestão ambiental em todos os setores da sociedade.

Uma gestão de forma adequada e eficiente pode fazer com que as cidades consigam resolver uns dos grandes problemas que é a redução dos resíduos sólidos, podendo torná-las uma sociedade lixo zero. 


\section{REFERÊNCIAS}

AGÊNCIA BRASIL. Disponível em

$<$ https://agenciabrasil.ebc.com.br/geral/noticia/2015-09/paises-adotam-na-onu-agenda2030-para-o-desenvolvimento-sustentavel>. Acesso em 20 de outubro de 2020;

BARBOSA, Rildo Pereira e IBRAHIN, Francini Imene Dias. Resíduos Sólidos. Impactos, Manejo e Gestão Ambiental. São Paulo:Érica,2014, $1^{\text {aedição; }}$

BLOG DA FUNDAÇÃO INSTITUTO DE ADMINISTRAÇÃO. Disponivel em $<$ https://fia.com.br/blog/sustentabilidade/\#: :text=A\%20no\%C3\%A7\%C3\%A3o\%20de $\% 20$ sustentabilidade $\% 20$ surgiu,os $\% 20$ recursos $\% 20$ naturais $\% 20 \mathrm{~s} \% \mathrm{C} 3 \% \mathrm{~A} 3 \mathrm{o} \% 20$ finitos. \&text=J\%C3\%A1\%20no\%20tocante $\% 20 \% \mathrm{C} 3 \% \mathrm{~A} 0 \% 20$ economia,teria\%20condi\%C3\% A7\%C3\%B5es\%20de\%20se\%20manter>. Acesso em 20 de Outubro de 2020;

DECRETO No 25.899 DE 24 DE MARÇO DE 2015. Disponível em $<$ https://leismunicipais.com.br/a/ba/s/salvador/decreto/2015/2589/25899/decreto-n25899-2015-regulamenta-o-art-5-da-lei-n-8474-de-02-de-outubro-de-2013-e-institui-oprograma-de-certificacao-sustentavel-iptu-verde-em-edificacoes-no-municipio-desalvador-que-estabelece-beneficios-fiscais-aos-participantes-do-programa-assim-comoo-art-5-da-lei-n-8-723-de-22-de-dezembro-de-2014-e-da-outras-providencias>. Acesso em 07 de Novembro de 2020;

ESQUERDA. Disponível em <https://www.esquerda.net/artigo/o-direito-\%C3\%A0cidade-por-davidharvey/30344\#: :text=O\%20direito\%20\%C3\%A0\%20cidade\%20\%C3\%A9,remodelar $\% 20$ os\%20processos\%20de\%20urbaniza\%C3\%A7\%C3\%A3o>. Acesso em 20 de outubro de 2020;

GOUVEIA, Nelson. Ciência \& Saúde Coletiva. Resíduos sólidos urbanos: impactos socioambientais e perspectiva de manejo sustentável com inclusão social. Rio de Janeiro. v. 17, n. 6, abril, 2012.

INSTITUTO PURUNÃ. Disponível em <http://www.institutopuruna.com.br/odsonu/?gclid=EAIaIQobChMInabk7ffP7AIVVAWRCh0wrQBeEAAYAiAAEgJtxfD_Bw E>. Acesso em 20 de outubro de 2020;

IPTU VERDE. Disponível em <http://www.iptuverde.salvador.ba.gov.br/>. Acesso em 07 de Novembro de 2020;

LEGISWEB. Disponível em

https://www.legisweb.com.br/legislacao/?id=264190\#: :text=1\%C2\%BA\%20Esta\%20

Lei\%20institui\%20a,e\%20os\%20demais\%20segmentos\%20da.acesso em 07 de novembro de 2020;

LUZ, Laíze Lantyer. O direito à cidad(e)(ania) das catadoras de luxo: O acesso à justiça ambiental em uma sociedade lixo zero. Direito Ambiental: Velhos Problemas, Novos 
Desafios. VAZ JÚNIOR, Rubens Sérgio S. Vaz; FIGUEIREDO NETO, Pedro Camilo De (coords.). Salvador: Editora Mente Aberta, p. 103-114, 2019.

MINISTÉRIO DO MEIO AMBIENTE. Disponível em $<$ https://www.mma.gov.br/cidades-sustentaveis/residuos-solidos/politica-nacional-deresiduos-solidos.html>. Acesso em 01 de novembro de 2020;

NSC TOTAL. Reportagem feito por Carolina Marasco. Disponível em $<$ https://www.nsctotal.com.br/noticias/dia-do-meio-ambiente-3-iniciativas-sustentaveisem-florianopolis >. Acesso em 05 de novembro de 2020;

PENSAMENTO VERDE, Disponível em $<$ https://www.pensamentoverde.com.br/sustentabilidade/curitiba-investe-administracaosustentavel-

cidade/\#: :text=A\%20administra\%C3\%A7\%C3\%A3o\%20da\%20capital\%20paranaens e,bolso $\% 20 \mathrm{do} \% 20$ cidad\%C3\%A3o\%20com\%20a>.Acesso em 07 de novembro de 2020;

PREFEITURA DE SALVADOR, Disponível em <http://sustentabilidade.salvador.ba.gov.br/>. Acesso em 06 de novembro de 2020;

REPOSITÓRIO DO CONHECIMENTO DO IPEA. Disponível em <http://repositorio.ipea.gov.br/bitstream/11058/8622/1/Direito\%20\%C3\%A0\%20cidade .pdf>. Acesso em 20 de Outubro de 2020;

SACHS, Ignacy. Estratégias de Transição para o Século XXI - desenvolvimento e meio ambiente. São Paulo: Studio Nobel/Fundap, 1993;

SENADO FEDERAL. Disponível em $<$ https://www12.senado.leg.br/emdiscussao/edicoes/residuos-solidos/realidadebrasileira-na-pratica-a-historia-e-outra>. Acesso em 01 de novembro de 2020;

SOUZA, Leite de Carlos; AWAD, Juliana di Cesare Marques; Cidades Sustentáveis, Cidades Inteligentes: Desenvolvimento Sustentável num Planeta Urbano, Porto Alegre: Bookman, 2014; 